Historic, Archive Document

Do not assume content reflects current scientific knowledge, policies, or practices. 



\section{Bordeaux Mixture}

Copper Sulphate..............6 pounds Quicklime.................... 4 pounds

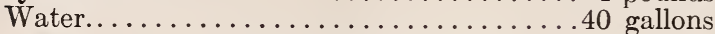

Dissolve the copper sulphate by putting it in a bag of coarse cloth and hanging this in a vessel holding at least 4 gallons, so that it is just covered by the water. Use an earthen or wooden vessel. Slake the lime in an equal amount of water. Then mix the two and add enough water to make 40 gallons. It is then ready for immediate use. For rots, moulds, mildews, and all fungous diseases.

\section{Ammoniaca Copper Carbonate}

Copper Carbonate................. 1 ounce Ammonia. . . . . . . . enough to dissolve the copper.... Water...................... 9 gallor

The copper carbonate is best dissolves in large bottles, where it will keep indefinitely, and it should be diluted with water as required. For same purpose as Bordeaux.

\section{Paris Green}

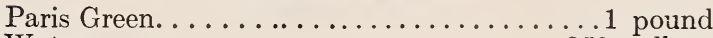
Water......................250 gallons

If this mixture is to be used upon peach trees, 1 pound quicklime should be added. Repeated applications will injure most foliage unless lime is added. Paris Green and Bordeaux can be applied together with perfect safety. The action of neither is weakened, and the Paris Green loses all caustic porperties. For insects which chew.

\section{Copper Sulphate Solution}

Copper Sulphate.. ................. pound

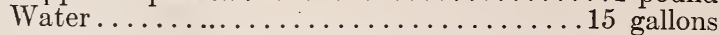
Lissolve the copper sulphate in the water, when it is ready for use. This should never be applied to foliage, but must be used before the buds break. For peaches and nectarines use 25 gallons of water. For fungous diseases.

\section{London Purple}

This is used in the same proportion as Paris Green, but as it is more caustic it should be applied with lime, or with the Bordeaux mixture. Do not use it on peach or plum trees. For insects which chew.

\section{Hellebore}

Fresh White Hellebore............. 1 ounce Water............................... gallons

Apply when thoroughly mixed. For insects which chew.

\section{Kerosene Emulsion}

Hard Soap. ............... $\frac{1}{2}$ pound

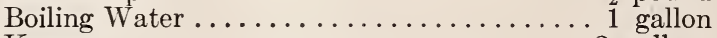
Kerosene...................2 gallons

Dissolve the soap in the water, add the kerosene, and churn with a pump for 5-10 minutes. Dilute 10 to 15 times before applying. For insects which suck, cabbage worms, and all insects which have soft bodies.

\section{Planting Calendar}

FEBRUARY. Sow in Hот Bed.-Early Beans, Cabbage, Cauliflower and Celery, Carrot, Broccoli, Cucumber, Lettuce, Parsley, Radish, Tomato.

MARCH. Sow in Hot BeD.-Early Beets, Beans, Cabbage and Carrots, Broccoli, Brussels Sprouts, Cauliflower, Celery, Cucumber, Egg Plant, Kohlrabi, Lettuce, Melon, Parsley, Peas, Pepper, Radish, Tomato. Plant In Open Ground.-Beet, Early Cabbage, Carrot, Cress, Lettuce, Onion, Peas, Radish, Round Spinach, Early Turnip, Potatoes, Onion Sets, English Bean.

APRIL. Sow in Hот Bed.-Sweet Corn, Cucumber, Egg Plant, Melon, Pepper, Squash, Tomato. Plant IN Open Ground.-Asparagus, Beets, Broccoli, Brussels Sprouts, Early Cabbage, Carrot, Cauliflower, Celery, Cress Kale, Kohlrabi, Lettuce, Melon, Onion, Parsley, Parnsnip, Peas, Radish, Round Spinach, Turnip, Sage, Potatoes, Top Onions.

May. Plant in Open Ground.-Asparagus, Beans, Beets, Broccoli, Brussels Sprouts, Late Cabbage, Carrot, Cauliflower, Celery, Sweet Corn, Cress, Cucumber, Kale, Lettuce, Melon, Okra, Onion, Parsley, Parnsip, Peas, Potatoes, Radish, Rhubarb, Kohlrabi, Salsify, Round Spinach, Squash, Tomato, Early Turnip, Herbs.

JUNe. Plant in Open Ground.-Lima Beans, Beets, Broccoli, Brussels Sprouts, Cabbage, Carrot, Sweet Corn, Cress, Cucumber, Kale, Kohlrabi, Lettuce, Nasturtium, Okra, Peas, Potatoes, Parsnip, Radish, Salsify, Spinach, Squash, Ruta Bagas, Melon, Herbs.

JUly. Plant in Opfin Ground.-Beans, Beets, Cauliflower, Carrot, Celery, Sweet Corn, Cress, Cucumber, Late Cabbage, Kale, Kohlrabi, Nasturtium, Okra, Peas, Parsnip, Winter Radish, Spinach, Squash, Turnip, Ruta Baga.

AUgust. Plant in Open Ground.-Bush Beans, Late Celery, Late Cabbage, Cucumber, Lettuce, Peas, Radish, Spinach, Turnip.

SEPTEMBER. Plant in Open Ground.-Cabbage, Cauliflower, and Lettuce for wintering in cold-frames, Asparagus, Celery, Kale, Mustard, Winter Radish, Spinach, Turnip.

\section{Measurements of an Acre}

The following will be found useful in arriving at accuracy in estimating the amount of land in different pieces of ground under cultivation; 5 yards wide by 968 yards long, contains one acre; as do also the following measurements: 10 yards wide by 484 yards long; 20 yards wide by 242 yards long; 40 yards wide by 121 yards long; 70 yards wide by $69 \frac{1}{2}$ yards long; 60 feet wide by 726 feet long; 110 feet wide by 369 feet long; 120 feet wide by 563 feet long; 220 feet wide by 198 feet long; 240 feet wide by $181 \frac{1}{2}$ feet iong, and 440 feet wide by 99 feet long. 


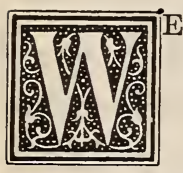

E take pleasure in handing you our catalogue of seeds. In it we have endeavored to offer everything of merit that is best adapted to this locality, and have omitted those varieties which repeated tests have shown to possess little or no value.

Our Stocks have been secured from a reliable source, and under proper conditions will produce the best of results; we do not, however, guarantee the seed or crop in any respect, as some times climatic conditions as well as other things occur which spoil or change either the seed or crop, or both.

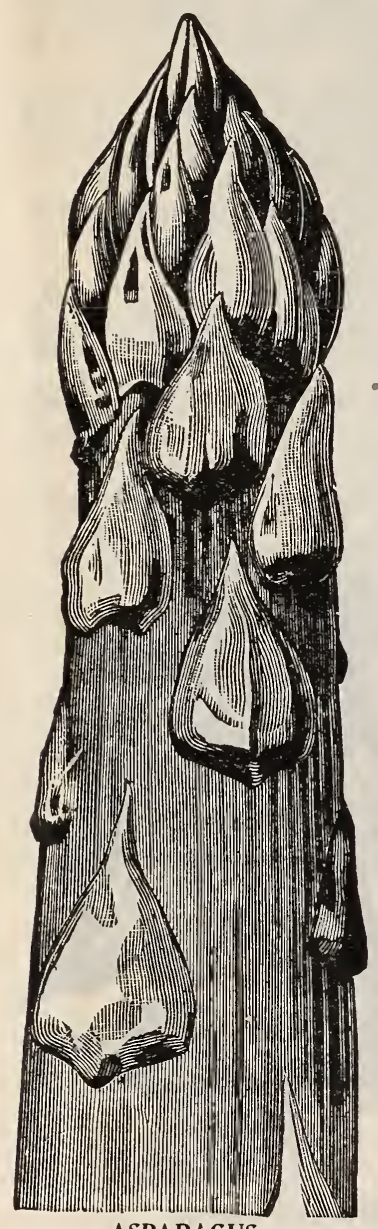

ASPARAGUS.

CONOVER'S COLOSSAL.

Prices are Net, delivered at our Express or Freight Depot, and are subject to change as the season advances, depending on shortage or surplus stock. If to go by mail, add $8 \mathrm{c}$. per $1 \mathrm{~b}$., and $15 \mathrm{c}$. for each quart, for postage. Two bu. Cotton Grain Bags, 20c. each.

PRICES ON LARGER QUANTITIES THAN HERE QUOTED ARE GIVEN UPON APPLICATION.

\section{ARTICHOKE.}

JERUSALEM. This variety is not produced from seed, but is cultivated for its tubers, which are especially valuable for stock feeding on account of their fattening properties; they are well adapted to any soil where corn and potatoes can be grown. Pk., 50c.; bus., $\$ 1.25$; bbl., $\$ 2.50$.

\section{ASPARAGUS.}

\section{Fr., Asperge. Ger., Spargel.}

Sow one ounce for sixty feet of drill. Sow in March or April, in rows one foot apart. When two years old transplant into permanent beds, which should be well and deeply ent beds, which should be well and deeply manured, and trenched to the depth of two
feet. Set the plants (in rows) from three feet. Set the plants (in rows) from three spreading out the roots, and covering from six to eight inches. On the approach of winter cover with manure or compost; fork the beds early in the spring, and apply a dressing of salt. Cut for use the second year after planting in permanent bed.

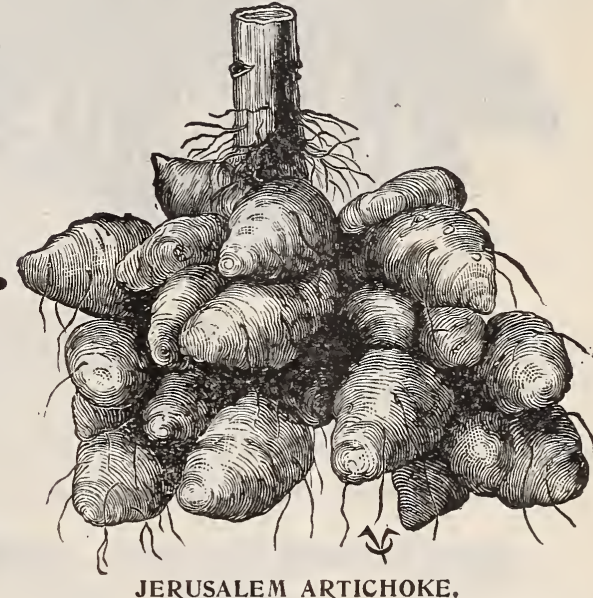

JERUSALEM ARTICHOKE.

\section{ASPARAGUS SEED.}

COLUMBIAN MAMMOTH WHITE. A new and entirely distinct variety that produces shoots that are white, and remain white as long as fit for use. Pkt., 5c.; oz., 10c.; $\frac{1}{4}$ lb., 25c. CONOVER'S COLOSSAL. The standard variety; of large size, tender and of excellent quality Pkt. 5c.; oz., 10c.; $\frac{1}{4}$ lb., $25 \mathrm{c}$.

PALMETTO. It is of very large size, even and regular in growth and appearance. It is a very early sort, and immensely productive and of the best quality. Pkt., 5c.; oz., $10 c_{.} ; \frac{1}{4}$ ib., 20 c.

\section{ASPARAGUS ROOTS.}

These prices do not include postage. If to go by mail, add at the rate of 50c. per $100 \mathrm{f} c \mathrm{r}$ the 2-year-old plant

COLUMBIAN MAMMOTH WHITE. 2-year-old roots.

CONOVER'S COLOSSAL. 2-year-old roots.

BARR'S MAMMOTH. 2-year-old roots.

PALMETTO. 2-year-old roots.

PRICES ON ANY VARIETY OF 2=YEAR=OLD ROOTS: PER 100, 75c.; PER 1000, \$6.00.

\section{BRUSSELS SPROUTS.}

One Ounce of Seed to 100 Yards of Row.

A variety of the Cabbage family, possessing the peculiarity of bearing upon its stem or stalk from 50 to 100 buds resembling miniature Cabbage heads. The leaves composing these heads resemble Savoy Cabbage in their crumpled texture and also in their color." The heads or buds, from 1 to 2 inches in diameter, form one of the most delicious garden vegetables, only equaled by the Cauliflower. Treat same as Cabbage. Autumn-grown Sprouts, drilled in May and transplanted in July generally do best, as the plants are quite hardy and the buds mellow under frost. Pkt., $\mathbf{5}$ c.; oz., 25c.

\section{BROCCOLI.}

One Ounce of Seed to 100 Yards of Row.

A plant much resembling the Cauliflower, and like it derived from the wild Cabbage. Broccoli requires a longer season to develop than Cauliflower. It has more numerous and stiffer leaves, and the heads are smaller. The seed is best sown in Midsummer and Autumn, and the plants carried over Winter for cutting in the Spring.

LARGE EARLY WHITE. Large white head, resembling Cauliflower. We offer an especially fine strain of Early White Broccoli, and strongly recommend its more general culture. Pkt., 10c.; oz., 50c.

PURPLE CAPE. Head purple in color. Superseded by superior varieties. Pkt., 10c ; oz., 50c.

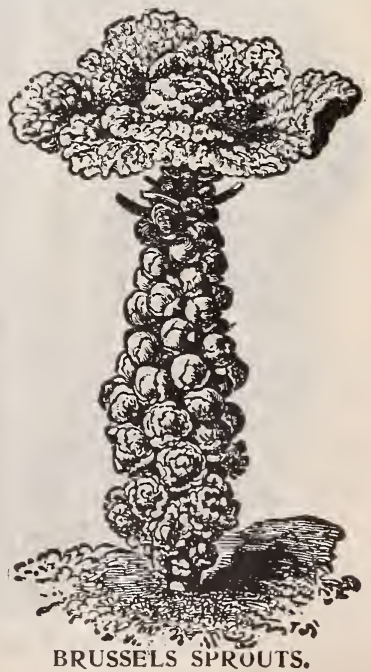


The Bountiful is a bean of merit
for earliness, productiveness and
quality.

\section{BUSH BEANS. Green Pod Varieties.} Do not fail to try our Dwarf
Black Wax Beans.

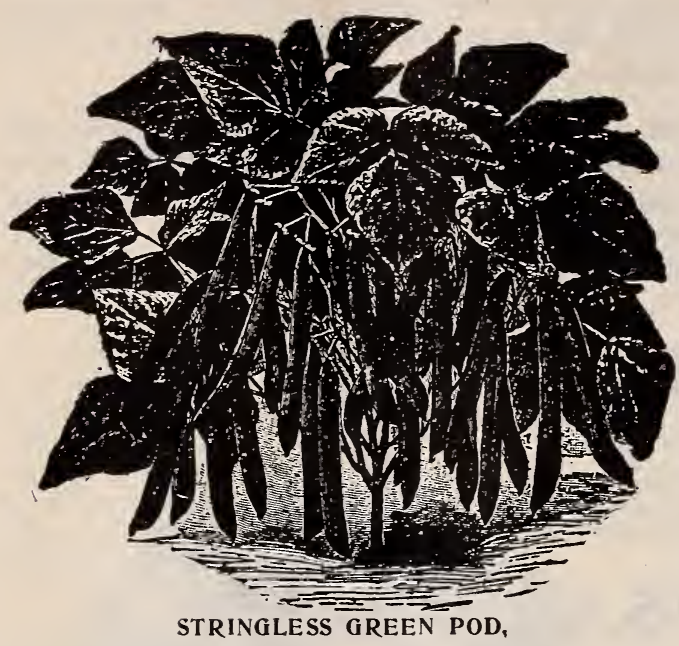

STRINGLESS GREEN POD. This bean produces a vine similar to Red Valentine, but develops pods to edible condition two or three days earlier than Valentine, that is to say in 30 to 31 days from germination, which extraordinary maturity for table at once advances the Stringless Green Pod to the first rank among table beans. The pods are green, not quite so round as Valentine and less curved. The pods are stringless-absolutely so-this quality at once placing the variety at the top of the list among table beans.

EXTRA EARLY REFUGEE. This is a great improvement on the old and well known Refugee, as it is a long way earlier, being fit to pick nearly as early as six weeks. It is more dwarf and compact in growth, while the pods are round, solid, tender, and of the most excellent quality when cooked for table use or for canning or pickling.

REFUGEE, OR 1,000 TO 1. The standard late pickling variety, matures two weeks later than the extra early kinds. Very valuable for pickling.

EARLY MOHAWK. One of the oldest and best known sorts. It is the hardiest of any of the beans, resisting a slight degree of frost very successfully. The leaves and vine are large, coarse and straggling. It is early and very prolific, with pods of medium quality, broad, flat, nearly straight and very long.

BOUNTIFUL BEANS. This new green podded bush bean is a heavy cropper and very early. It is a stringless variety and a careful selection from one of the standard sorts. Its hardiness and great productiveness make it one of the very best bush beans.

LONG YELLOW SIX WEEKS. Pods are long, flat, straight, green, edible at 30 days from planting.

LONGFELLOW BEANS. This new bean has long green pods, is exceedingiy prolific, always solid, of delicious flavor, is tender and remarkably early. It matures its crop very regularly and withstands adverse conditions well.

EXTRA EARLY RED VALENTINE. Pods develop to an edible condition in thirty-two days from germination. Color of pods, light green and semi-transparent. Form of pods, round and slightly curved. Succulent, prolific and quite free from strings, continuing long in edible condition.

DWARF HORTICULTURAL. The best shell bean for fine quality.

\section{BEAN PRICE LIST-GREEN PODS.}

Stringless Green Pod.

Extra Early Refugee

Refugee, or 1,000 to $i$.

Early Mohawk

Extra Early Red Valentine

Bountiful.

Long Yellow Six Weeks.

Longf ellow.

Dwarf Horticultural.

Navy.

Prolific Tree

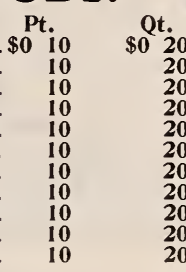

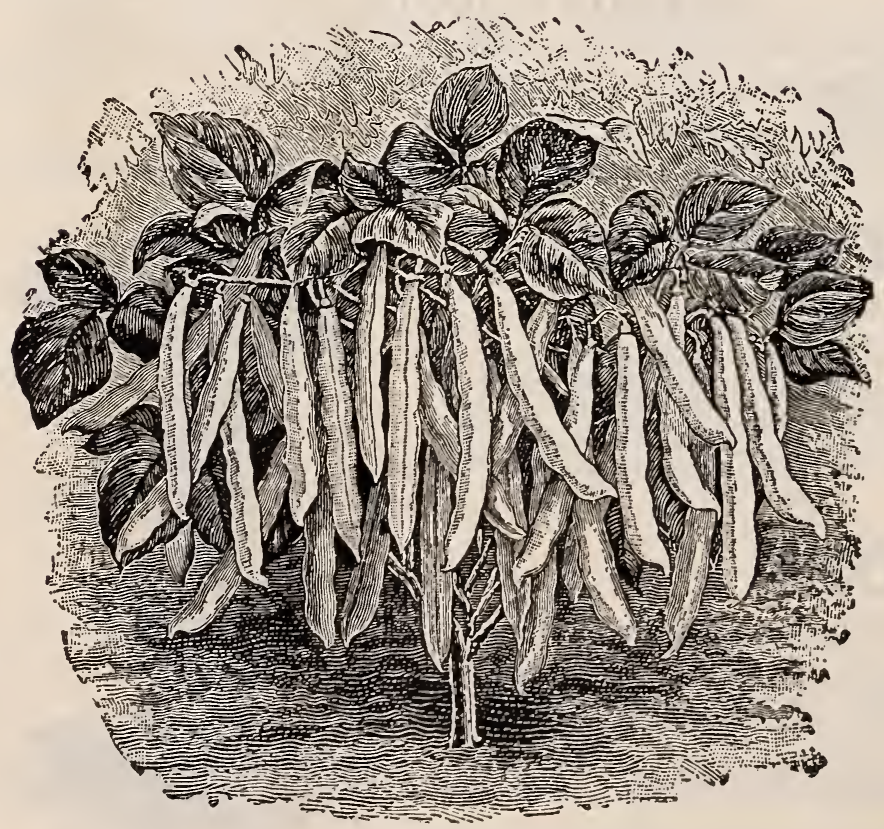

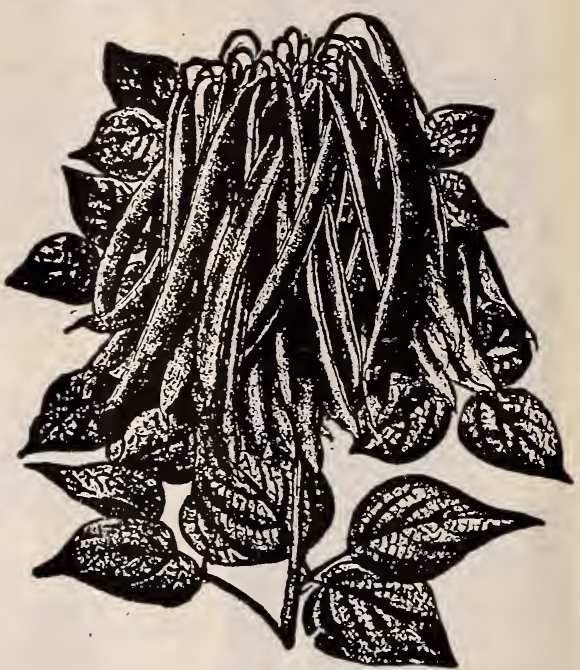

BOUNTIFUL BEAN.

BURPEE'S BUSH LIMA. The only Bush form of the true large Lima. Bushes grow to 18 inches in height and always erect.

DREER'S BUSH LIMA. The pods are heavy and thick. It is productive and of excellent quality.

HENDERSON'S BUSH LIMA. This is a bush form of the small Lima pole bean. It is a bean of great merit, the most productive of any.

BUSH LIMA PRICES.

Burpee's Bush Lima. .

Henderson's.

Dreer's Bush Lima..

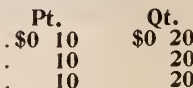

OUR LEADERS IN BEANS:

EXTRA EARLY RED VALENTINE.

STRINGLESS GREEN POD.

DWARF BLACK WAX. 


\section{BUSH BEANS. WAX PODDED VARIETIES.}

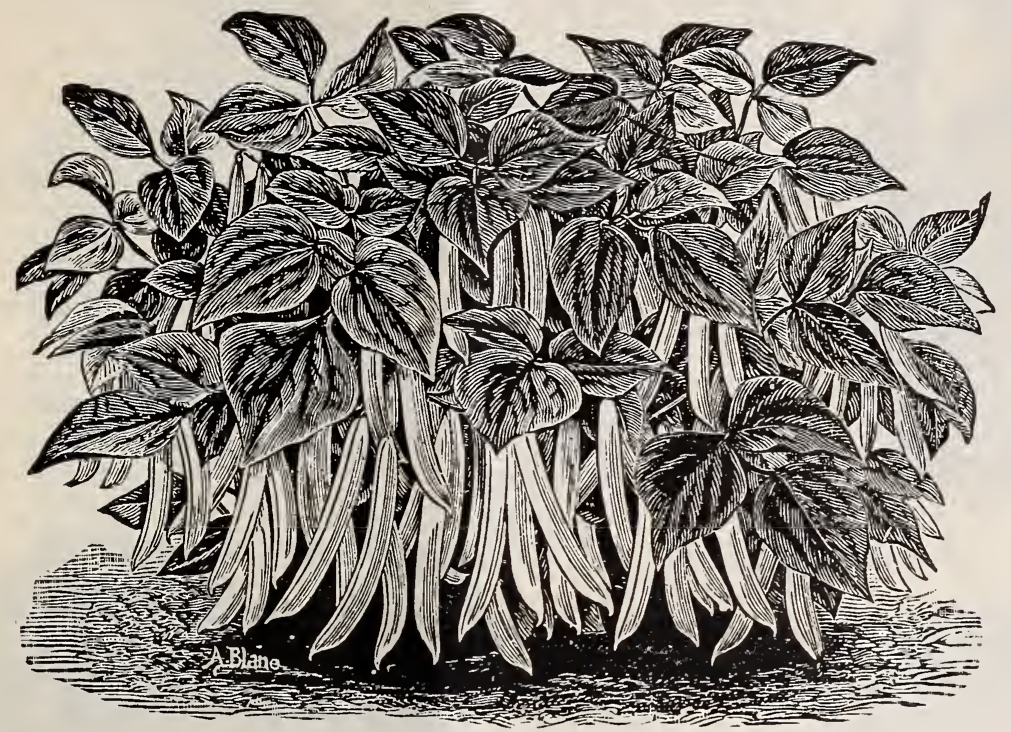

WARDWELL'S DWARF KIDNEY WAX.
Do not overlook the Kentucky Wonder Pole Bean.

WARDWELL'S DWARF KID= NEY WAX BEAN. Hardy and productive, pods long, broad, flat and of a delicate waxy yellow. brittle and entirely stringless. The yield considerably exceeds that of the Common Golden Wax and is equally as early.

DWARF BLACK WAX. The old standard Black Wax bush bean. It is so good that it is worthy of special notice. The pods are round, brittle, of handsome golden yellow color, and of buttery flavor when cooked. Do not forget the old meritorious kind when looking over the list, and include this in your orders.

CURRIE'S RUST PROOF WAX. Seed black; a fine sort. Rust proof, tender thick fleshed pods, early and very productive.

GOLDEN IVAX. The old standard wax sort. It is productive, early, prolific, and on the whole is yet among the best for family use.

IMPROVED GOLDEN WAX Rust proof. An improvement on the old Golden Wax. The pod is somewhat round, meaty and entirely rust proof.

FLAGEOLET WAX. A large bush wax variety; seed large,

purplish red; excellent as a snap bean, and in great faror as a dry shell bean.

PENCIL' POD BLACK WAX. Grows a taller, stronger and more vigorous bush than the Prolific Black Wax, which is one of its parents. Pods are long, slender, straight and shaped very much like a pencil.

DAVIS KIDNEY WAX. It is adapted alike for the canner, market gardener, shipper or amateur. The dry bean is large, kidney shaped and white in color, making it one of the best for cooking in the dry state. The pods are long, mealy, stringless, and a beautiful yellow color. It stands shipping better than any other, and is one of the best of the wax podded varieties.

\section{BEAN PRICE LIST - Wax Pods}

Wardwell's Kidney Wax.

Currie's Rust Proof Wax...

Dwarf Black Wax.

Flageolet Wax.

Golden Wax.

Golden Wax........................

Improved Golden Wax.

Pencil Pod Black Wax
Davis Kidney Wax. .

Keeney's Rustless Goiden Wax

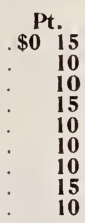

Pole or Running Varieties.

LARGE WHITE LIMA. Very productive, of good flavor. KING OF THE GARDEN LIMA. Very large.

EXTRA EARLY JERSEY LIMA. Early and productive.

WHITE CREASE BACK. Very early. prolific.

DUTCH CASE KNIFE. Long green flat pods, early and

DREER'S IMPROVED LIMA. A late Lima of fine flavor.

LAZY WIFE. Exceedingly productive and easily gathered.

EARLY GOLDEN CLUSTER WAX. The finest wax pole bean.

RED SPECKLED CUT SHORT OR CORN HILL.

KENTUCKY WONDER OR OLD HOMESTEAD.

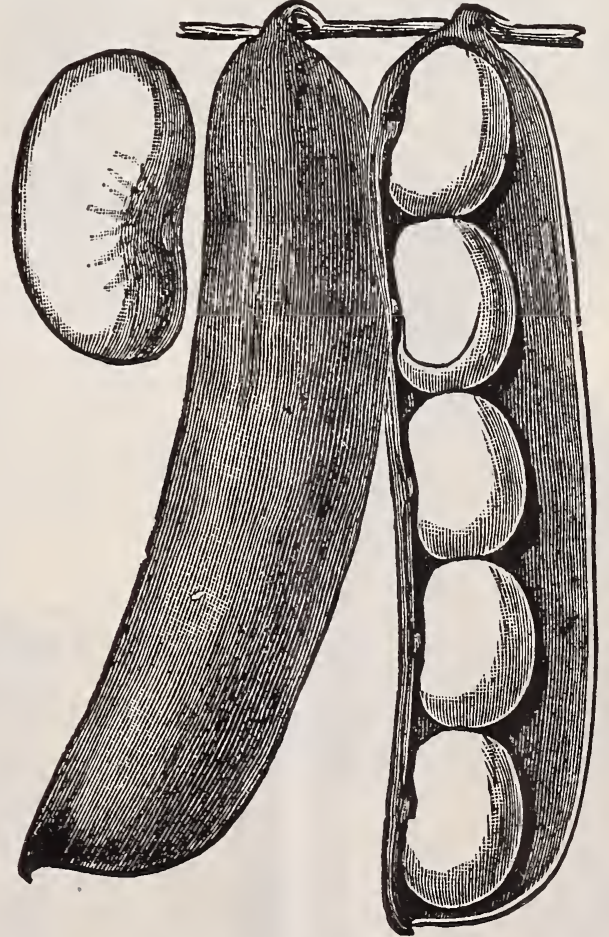

LARGE WHITE LIMA.

WHITE RUNNER BEAN. Cultivated chiefly for its flowers, though the large, white beans are of fair quality, either green shelled or dry. Vines and leaves large and coarse; blossoms in long racemes, large, pure white; pods large, broad, coarse; beans large, kidney-shaped, thick.

SCARLET RUNNER BEAN. Similar to the last, but with scarlet blossoms, and the beans are lilac-purple, variegated with black. 


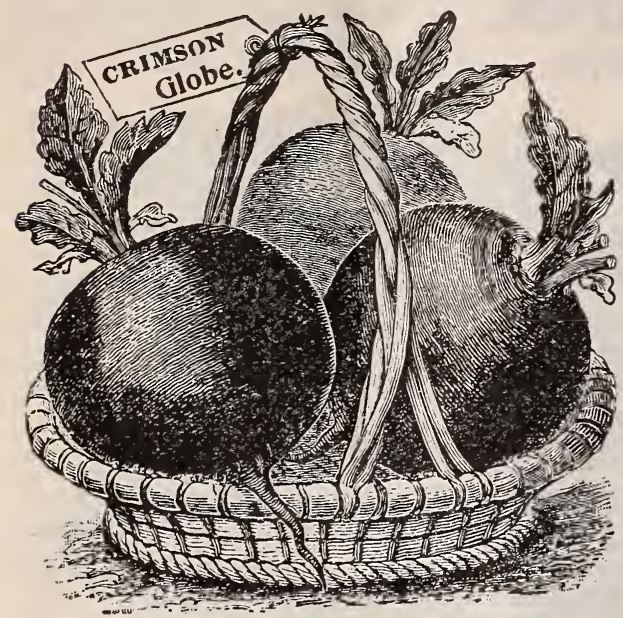

CRIMSON GLOBE.

\section{TABLE BEETS.}

CRIMSON GLOBE. This is one of the finest beets yet introduced. Roots are not large, but very handsome. Round, and a clean, smooth surface. Leaves very small, with slender stems. We can recommend this beet for bunching, as its color and shape make them quick sellers.

EARLY EGYPTIAN. The well-known early variety。 Color extra dark, shape flat, quality excellent.

BASTIANS. An extra early variety, much esteemed by market men East and South. Color light.

HIALF LONG BLOOD. One of the best for winter use. The roots are only half as long as the Long Blood, but weigh as much on account of their thickness. They are always smooth and handsome, and their rich, dark red flesh is very sweet, crisp and tender, never becoming woody, even in the exposed portions.

LONG SMOOTH BLOOD. The standard long late sort. Very dark blood-red flesh, quality fine.

EARLY BASSANO. A good early variety, similar to Egyptian in shape, but of lighter color.

SWISS CHARD, OR SILVER. Used for its leaves.

EDMAND'S EARLY BLOOD TURNIP. The best sort for general crop. In quality one of the finest, exceedingly dark, shape globular, having only one tap root. Very popular with market men.

IMPROVED BLOOD TURNIP. An improved variety of the Early Blood turnip of deep, blood-red color; fine form and flavor. An excellent-market sort.

DETROIT DARK RED TURNIP. Quality good, sweet and tender; color deep red

roots are turnip shaped, with small tap roots.

DEWING'S EARLY BLOOD TURNIP. A good variety for main crop. Keeps well. Like Edmand's, but lighter color.

LENTZ TURNIP. Of similar size and shape to the Bastian Turnip; top small. Early and profitable.

\section{CROSBY'S EGYPTIAN BEET.}

A selection from that old market beet, Early Egyptian, which retains the earliness of the parent stock, and has added thickness, giving it a more desirable shape. It is the deepest red, almost black in color, and is of finer quality than the Egyptian, being sweeter and even more tender and smoother. A very desirable sort for sniall beets for early market, as it is in presentable market shape quicker than any variety. It is a very rapid grower, and can be sown outside as late as July. Price of all Table Beets, oz., 5c.

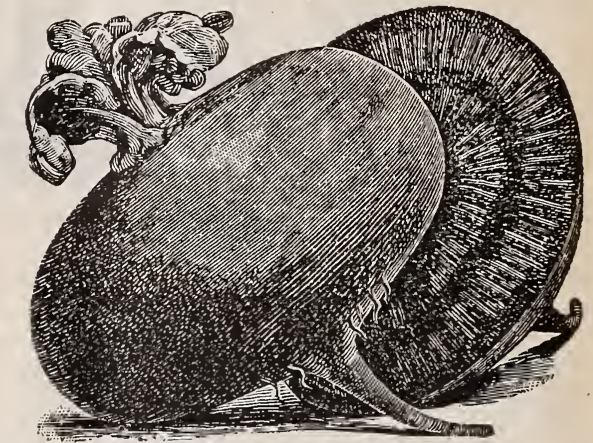

CROSBY EGYPTIAN.

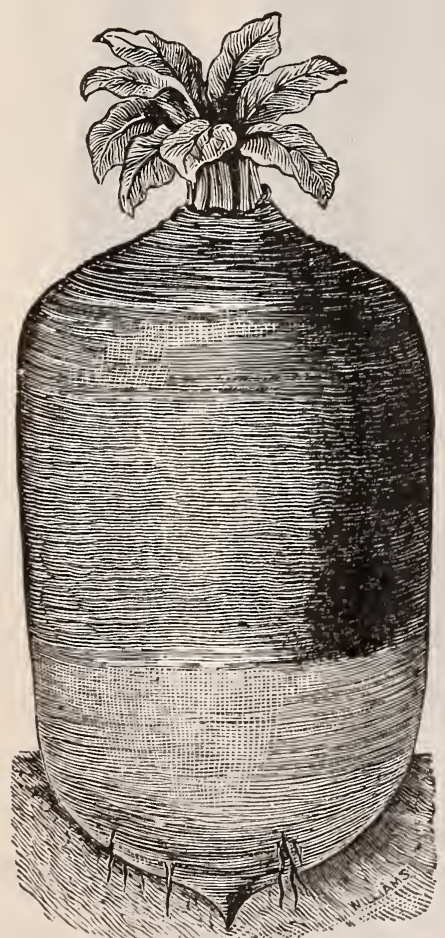

GOLDEN TANKARD MANGEL.

\section{CATTLE BEETS OR MANGELS.}

LONG RED. A large, long variety grown for stock feeding. It stands up well above the surface; color light red; flesh white and rose colored.

YELLOW GLOBE. Globular shaped roots. More productive than Long Red in shallow soil. Very nutritious and a good keeper.

GOLDEN TANKARD. Shape cylindrical, color deep rich yellow, flesh yellow circled with white. Unequaled for feeding stock.

ORANGE GLOBE. We think this one of the best varieties of mangel wurzel grown for stock feeding. It has exceedingly small tops and few leaves; leaf stalks and blades green; roots medium sized, uniformly globe shaped, having a very small tap and few side roots; color of skin deep orange yellow; flesh white and of excellent quality. The roots grow almost entirely above ground, making them admirably adapted to shallow ground and very easy to harvest. Price of all Mangels, 2 ozs, for $5 \mathrm{c}$.

\section{SUGAR BEETS.}

Five Pounds Will Sow One Acre.

VILMORIN'S IMPROVED SUGAR. In general the most desirable beet for the factory is the one containing the largest percentage of sugur In this variety we have one of the richest beets in cultivation; not only that, but it will do better on new lands, suffer less from an excess of nitrogen, and will keep the best of any. In size it is medium or little below, yielding from ten to sixteen tons per acre, and containing from 16 to 18 per cent. of sugar.

KLEIN WANZLEBEN. A little larger than Vilmorin's Improved, vielding from twelve to eighteen tons per acre, and containing about the same amount of sugar. It grows below the surface, and the green leaves are rather large and spreading, with wavy edges. A little hardier, and easier grown than Vilmorin's Improved. Price of all Sugar Beets, 2 ozs. for $5 \mathrm{c}$.

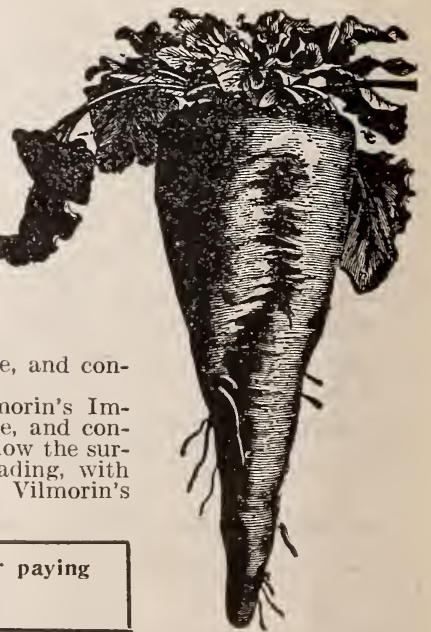




\section{CABBAGE.}

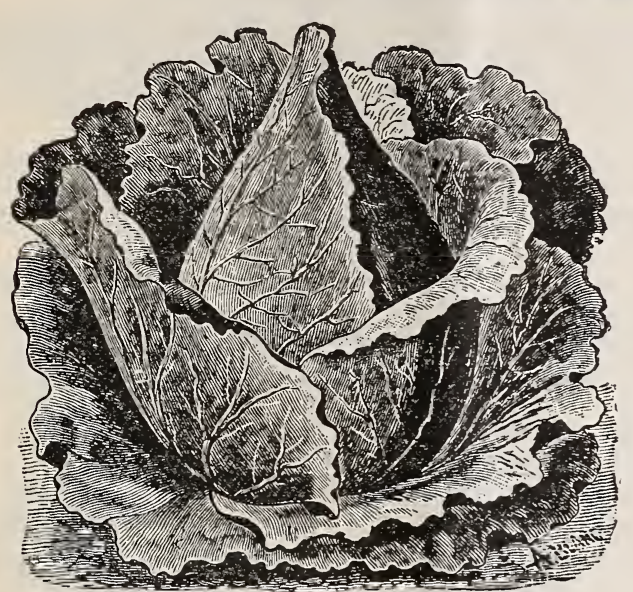

EARLY JERSEY WAKEFIELD.

SURE HEAD. A fine variety for main crop. A good shipper and sure header.

HOLLAND. The favorite winter cabbage with market gardeners. It is as hard as a rock, and a small head will weigh as much as a large head of any other variety. The leaves lap over and make a head in which there is no waste.

PREMIUM FLAT DUTCH. This variety of late cabbage is a standard in all sections for winter use. Our selected stock is unsurpassed. It makes a large solid head which keeps long without bursting, and is adapted to a more varied climate than probably any other variety we grow.

Our stock of Premium Flat Dutch has given excellent satisfaction both north and south for many years, and its great popularity at home puts its merit beyond question.

LARGE LATE DRUMHEAD. A late variety of large size.

Start the children right. Set apart space in the yard for a garden. No matter how small a piece of ground, the child will derive both pleasure and profit from it. The patience and care which must be exercised is an education in itself while the nature study and good wholesome exercise are bound to be a benefit and create ambition.

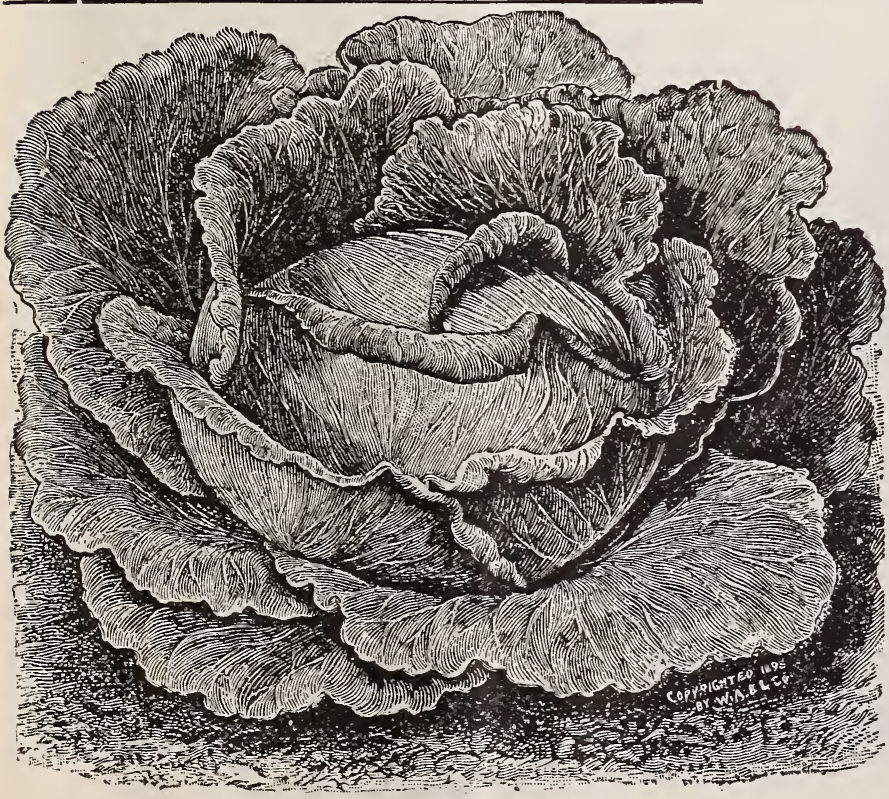

PREMIUM FLAT DUTCH.
EARLY JERSEY WAKEFIELD CABBAGE. Our select stock. This is one of the most important varieties in the list. Great care must be exercised in the growing of the seed to have it pure and true to type. We give especial attention to the growing of our Wakefield stock, and its uniform excellence s a source of gratification to us.

EARLY SPRING CABBAGE. The earliest flat head. As early as Jersey Wakefield. Yields one-third more than the early pointed heads. Solid, uniform and finely grained heads. Stem is short and extends but little into the head. Entirely free from any rankness of flavor.

EARLY WINNINGSTADT. An early variety of excellent quality, not as early as the Wakefield.

HENDERSON'S EARLY SUMMER. A standard summer variety. We have the true stock.

FOTTLER'S EARLY BRUNSWICK. An early fall variety, well known and popular.

ALL HEAD EARLY. One of the finest early flat-head cabbages.

EARLY YORK. A standard pointed head variety, second early.

EARLY DWARF FLAT DUTCH. An early cabbage of good size. Heads are flat and very solid.

MAMMOTH ROCK RED. The largest heading of any of the red sorts, of deep rich color and excellent quality.

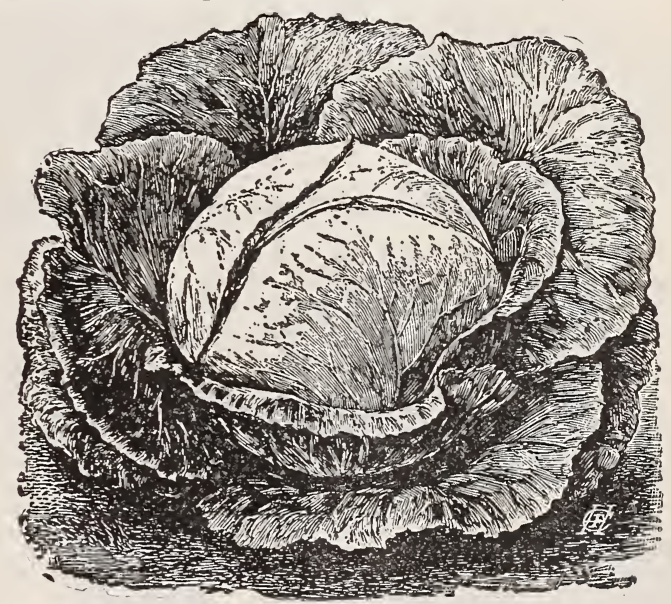

HOLLAND CABBAGE.

DANISH BALL HEAD. A good main crop variety; popular with many of the gardeners. Similar to our Holland, but not so uniform in heading.

SAVOY GREEN GLOBE. Deep Green.

SAVOY IM. AMERICAN. The finest flavored of all the cabbage family, large and solid.

\section{CABBAGE SEED PRICES.}

\begin{tabular}{|c|c|}
\hline Early Jersey Wakefield...... . & kt. \\
\hline Early Spring $\ldots \ldots \ldots \ldots \ldots$ & \\
\hline arly Winningstadt $\ldots \ldots \ldots$ & \\
\hline Henderson's Early Summer... & \\
\hline Fottler's Early Brunswick. . . . & \\
\hline All Head Early $\ldots \ldots \ldots \ldots \ldots$ & \\
\hline Early York. ............. & \\
\hline Early Dwarf Flat Dutch $\ldots \ldots$ & \\
\hline Mammoth Rock Red....... & \\
\hline Sure Head $\ldots \ldots \ldots \ldots \ldots$ & \\
\hline Holland $\ldots \ldots \ldots \ldots \ldots \ldots$ & \\
\hline Premium Flat Dutch $\ldots \ldots \ldots$ & \\
\hline Large Late Drumhead........ & \\
\hline Danish Ball Head. . . . . . . . . . & \\
\hline avoy Im. American $\ldots \ldots \ldots$ & \\
\hline . Louis Market. . . . . . . . & \\
\hline u mn King & \\
\hline
\end{tabular}




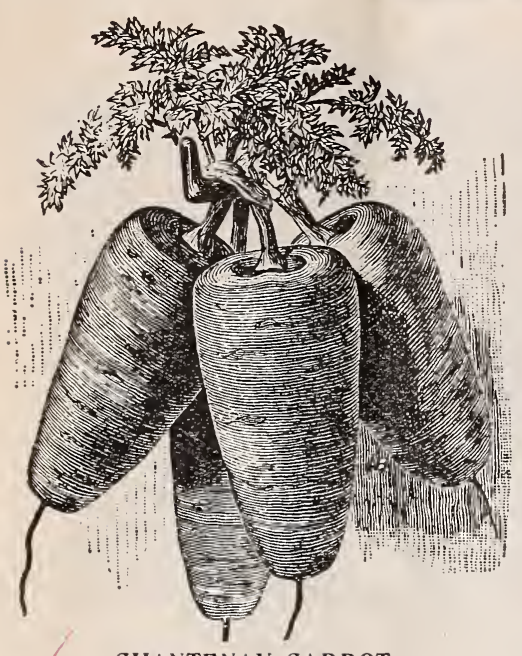

CHANTENAY CARROT.

\section{CARROTS.}

CHANTENAY. Tops medium size; necks small; roots tapering slightly, but uniformly stump rooted and smooth; color, deep orange red; flesh very crisp and tender. Although this is a medium early sort, it furnishes roots of usable size as early as any, is a heavy cropper, and is undoubtedly one of the best for both the market and private garden, while its great productiveness makes it very desirable as a field sort.

IMPROVED LONG ORANGE. The most popular of the older sorts for farm use on mellow soil. An improvement obtained by years of careful selections of the best formed and deepest colored roots of the old Long Orange. Roots comparativel shorter than the Long Orange and smoother, but so uniform and true that the bulk of the crop will be greater. Oz., 5c.

ST. VALERY. A good late variety. It grows long, shape uniform, taperin. from a wide shoulder to a point. Oz., 5c.

LARGE WHITE BELGIAN. Grows one-third out of the ground. Root pure white, green above ground, with small top. Flesh rather coarse. The roots, on light, rich ground, grow to a large size, and are extensively grown for stock feeding. Oz., 5 c.

EARLY SHORT HORN. A fine early variety, good for home use. Eastern market gardeners use this sort for bunching. Oz., $\mathbf{5 c}$.

GUERANDE, OR OX HEART. Tops small for the size of the roots, which are comparatively short, but often reach a diameter of 7 inches, terminating abruptly ir a small tap root. Flesh, bright orange, fine grained and sweet. This is a desirable variety for soil so hard and stiff that longer growing sorts would not thrive in it. When young, excellent for table use, and when mature equally good for stock. Oz., $\mathbf{5} c$

DANVERS. Grown largely on account of its great productiveness and adaptability to all classes of soil. Tops medium sized, coarsely. divided. The smooth and handsome roots are deep orange, of medium length, tapering uniformly to a blunt point; flesh sweet, crisp, tender and of a deep orange color. This is a popular field variety, and although the roots are shorter they produce as large a bulk as the longer field sorts and are more easily harvested. Oz., 5 c.

\section{CARROTS-For Stock Feeding.}

These are esteemed highly as a wholesome and nutritious addition to the winter feeding of stock when dependent on grain and dry forage. They are easily raised and keep in excellent condition when properly stored.

The most popular Improved Short White is thick at the shoulder, and tapers rather quickly, being from six to eight inches in length.

The Large White and Yellow Belgian are long and slender; as fully one-third to one-half of the root grows above the surface, they are, however, easily pulled. They differ only in color of the flesh, as indicated by their respective names.

LONG ORANGE and ST. VALERY (offered above) are also very productive in deep soils.

Price, all Varieties of Field Carrot, oz., 5c.; 3 ozs. for $10 \mathrm{c}$

\section{CAULIFLOWER.}

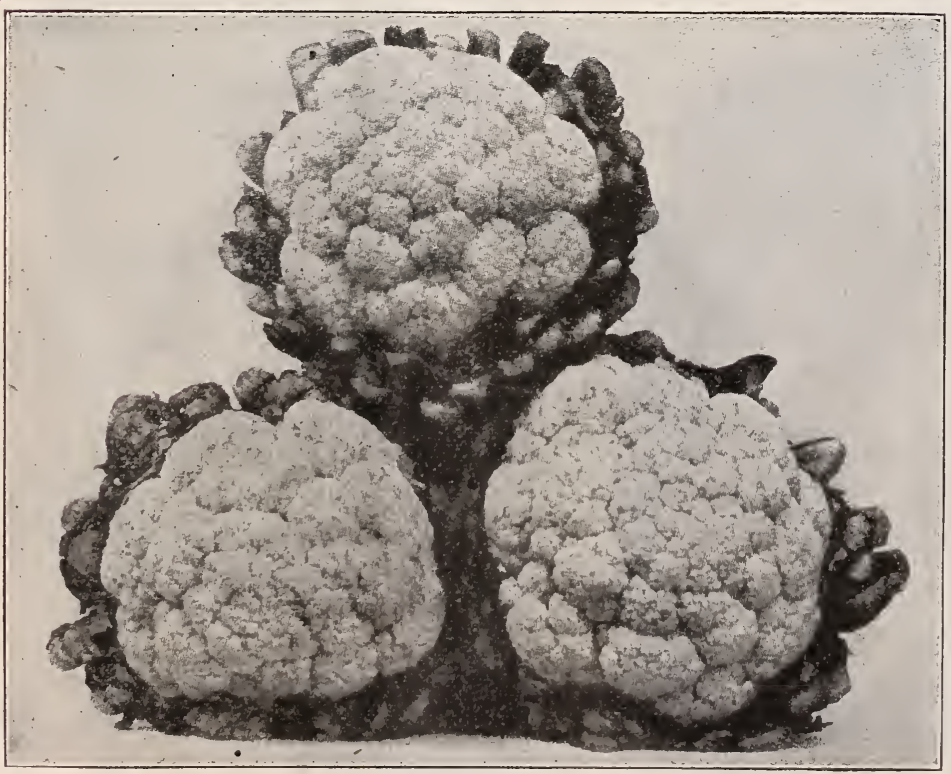

EARLY SNOWBALL CAULIFLOWER

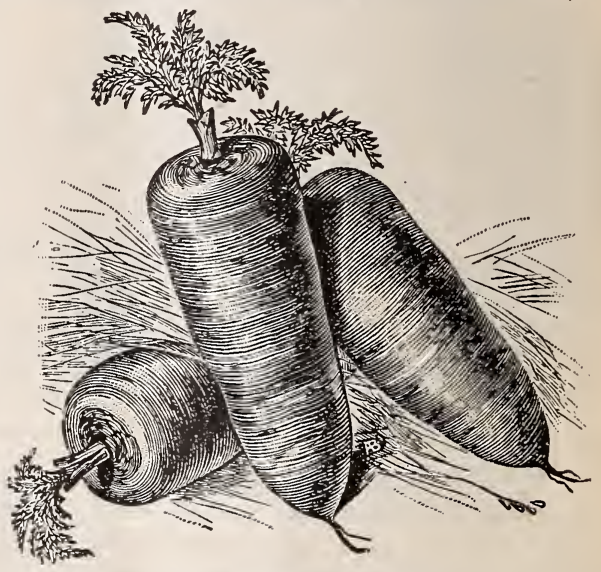

DANVERS CARROT.
EARLY SNOWBALL. The leading cauliflower among cauliflower growers, and unquestionably the purest strain of "Snowball" cauliflower seed to be had. Heads uniform, of desirable market size and of snowy whiteness. After seven years' competitive tests it is pronounced by expert cauliflower growers to be the best for both early and late planting. Successful frame growers of cauliflower say that under glass culture our Snowball outclasses any strain of cauliflower seed known to them. This strain of ours is their favorite for early, for late and for forcing. Strong recommendations, surely. Pkt., $15 \mathrm{c}$.

LARGE ALGIERS. A valuable late sort sure to head, of the best quality, and very popular with market gardeners everywhere. popular with market gardeners every where. protecting the heads so that they will enprotecting the heads so that they will en-
dure uninjured a frost that would ruin othe: sorts. One of the very best of the late sorts, Pkt., 5c.

Superior stocks are necessary to the prosperity of the market planter. The inferior article may be more attractive at the beginning, because it costs less, but the superior seed gives the more valu= able product. You cannot afford to do without the best. 


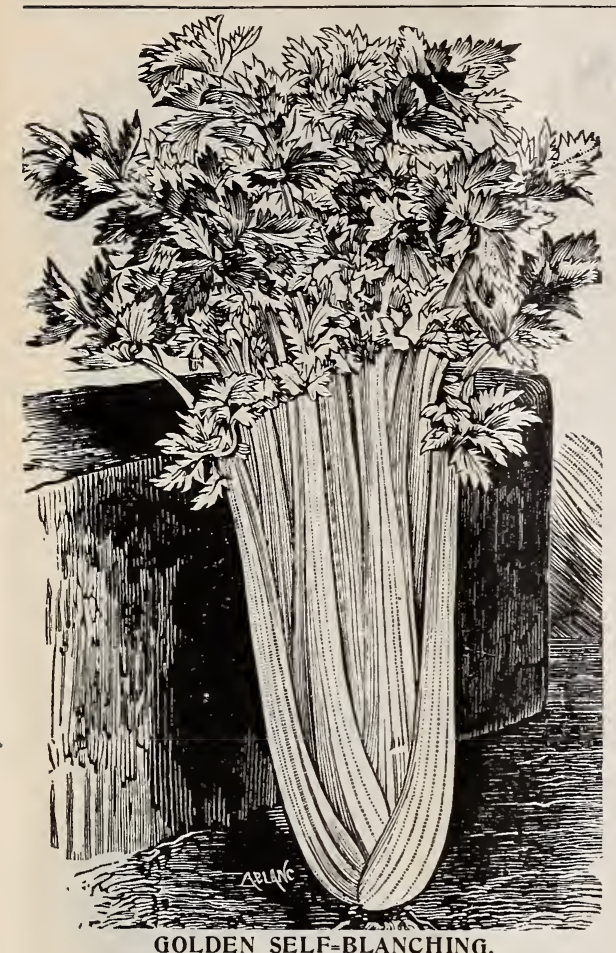

\section{CELERY.}

GOLDEN SELF=BLANCHING. The best self-blanching sort. It acquires a handsome golden color without having to be hilled up, which makes

WHITE PLUME. A good self-blanching sort, good for fall use, but does not keep well. Pkt., 5c.; oz., 25c.

GIANT GOLDEN HEART. This rariety attains a large size, but still remains crisp and tender. It is a fine keeper and is the favorite on the Chicago market. Pkt., 5c.; oz., $15 \mathrm{c}$.

KALAMAZOO. This is the variety used by the celebrated celery growers of Kalamazoo, Mich., and is of great merit. Pkt., 5c.; oz., $\mathbf{1 5 c}$.

PERFECTION HEARTWELL. A finely flarored, good keeping sort, hardy and solid. Pkt., 5 c.; oz., 15 c.

CRAWFORD'S HALF DWARF. The favorite rariety in eastern markets, a good keeper of vigorous growth. Pkt., 5c.; oz. 15c.

ROSE RIBBED PARIS SELF=BLANCHING OR GOLDEN ROSE. This is a sport of the Golden Self-Blanching celery and possesses all the good qualiities for which that variety has become so famous. It has the same beautiful rich golden yellow color, is self-blanching to the same remarkable degree, and differs only in color of the ribs. These are a very attractive shade of rose, which deepens as the season advances. This ornamental feature gives the whole plant a most pleasing appearance that cannot fail to make it of great value for market, while no celery could be of finer quality. Pkt., 5c.; oz., 25c.

PINK PLUME. Similar to White Plume, but having stalks suffused with pink. Pkt., 5c.; oz., $15 \mathrm{c}$.

GIANT PASCAL. This is the best keeper of all the late sorts, very solid and crisp. This variety is unsurpassed for market garden. Pkt., 5c.; oz., 15c.

\section{WINTER QUEEN.}

Most Popular of all Celeries for Winter.

It has the strong robust growth of the Giant Pascal, but the plants, being only of medium height, are of better length for bunching for market as well as more desirable for serving on the table. Their compact habit makes considerable less labor in earthing up the plants to blanch, and the rows can be planted more closely in the field. Of vigorous growth, each plant makes a large number of fine stalks (magnificent large heart of rich golden yellow) which are broad, thick and heavily ribbed. Stored for winter it is an excellent keeper, and when taken out the blanched stalks are firm and crisp; entirely free from stings, brittle and of sweet flavor. Most highly recommended. Pkt., 5c.; oz., 15c.

\section{GERMAN CELERY OR CELERIAC.}

LARGE SMOOTH PRAGUE. Has a large smooth root, and is the finest of all celeriac. Pkt., 5c.; oz., $15 \mathrm{c}$.

APPLE SHAPED. Not as smooth as the above but of good form. Pkt., TC.; OZ.; TC. Pkt., 5c.; oz., 15c.

\section{CELERY PLANTS.}

We are prepared to quote Celery Plants at the proper time. We arrange to have all the standard varieties. WRITE FOR We arrange
PRICES.

\section{CUCUMBER.}

EARLY CLUSTER. Vines rigorous, producing the bulk of the crop near the root and in clusters, Fruit short, uniformly thick end dark green, but paler at blossom end. A very productive sort. Pkt., 5c.; oz.,

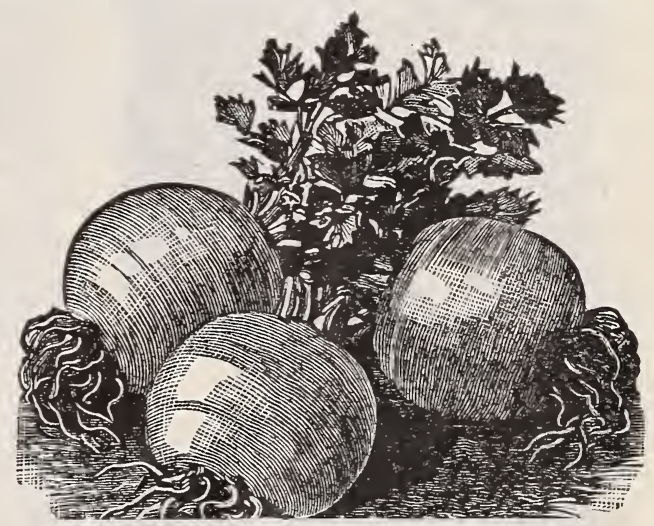

CELERIAC.

NICHOL'S MEDIUM GREEN. A valuable and handsome variets, in shape between White Spine and Long Green. An excellent sort for pickles and useful for forcing. Very prolific. Fruit straight and smooth; color, dark green, flesh tender and crisp. Pkt., 5c.; oz, 10c.

EARLY'FRAME OR SHORT GREEN. An excellent sort both for table use and for pickling. Fruit straight, handsome, smaller at each end, bright green; flesh tender and crisp, and makes fine pickles. Pkt., 5c.; oz., 10c.

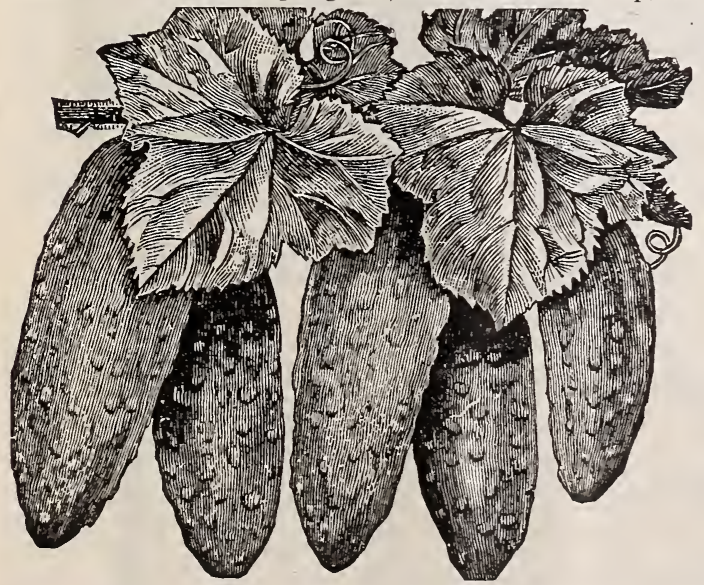

JERSEY PICKLE. Sixty days to make pickles. It is productive and is said to "green" better than any other variety, and to size, two to three inches long, in sixty days. Early summer sowings in thirty days. Pkt, 5c.; oz, 10c.

GREEN PROLIFIC OR BOSTON PICKLING. A favorite with pickle growers and commercial gardeners, and good for table use. Quite productive. Fruit small, uniform in size. Pkt., 5c.; oz., 10c. IMPROVED LONG GREEN. Not so abundant a bearer as the preceding sorts, though recommended to all who put up their own pickles. Fruit long and slim, not surpassed in quality by any variety. This is not the ordinary Long Green but a much superior sort, being longer and of better proportion. Pkt., 5c.; oz., 10c.

CHICAGO OR WESTERFIELD PICKLING. A variety esteemed above all others by Chicago market gardeners, and grown extensivley for the large pickling establishments in this vicinity. Fruit medium length, pointed at each end, with large and prominent spines. Color a deep green. It combines all the good qualities of an early cucumber. Pkt., 5c.; oz., 10c.

EVERGREEN WHITE SPINE. Is the most profitable cucumber for the market gardener. Best for the greenhouse, hot bed or for outdoor culture. The earliest and most productive variety. Long, straight, and of rich deep green color throughout, brings more mone per dozen on the street than any other variety. Pkt., 5c.; oz., 10c.

ARLINGTON. A selection from the White Spine, being more pointed at each end. The young fruits are unusually crisp and tender, and are of very dark green color, so that the variety is considered by

CHICAGO OR WESTERFIELD'S PICKLING. 
Send the address of your friends who are interested in a good garden and they will receive a copy of this $C$ atalogue.

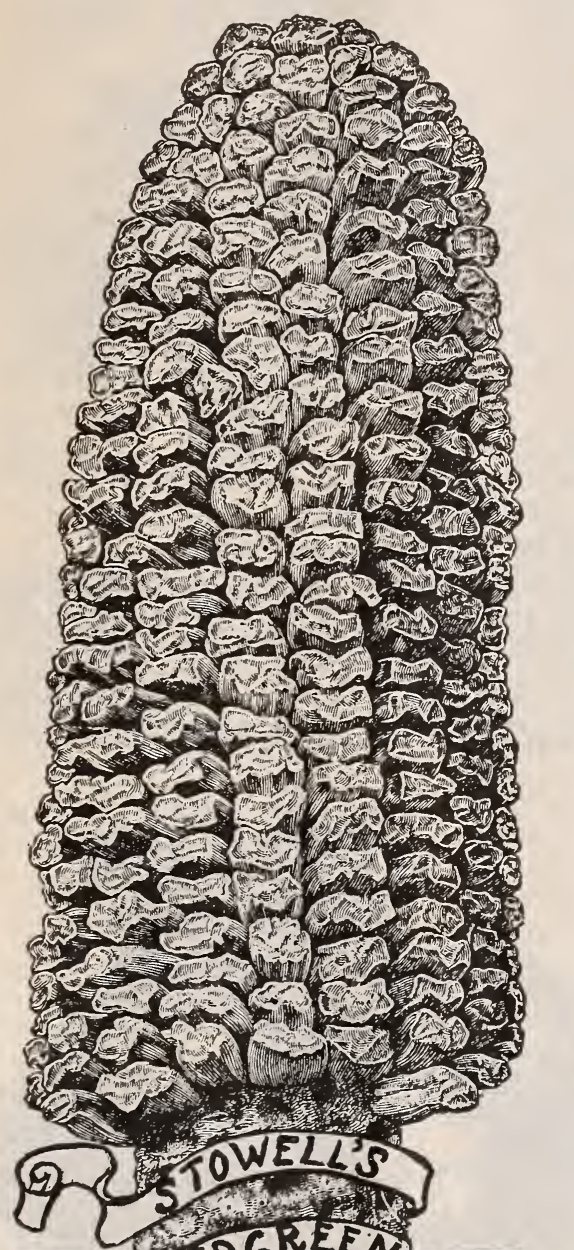

\section{CORN.}

CULTURE. A rich, warm, alluvial soil is best, but excellent sweet corn can be raised on any good, ordinary soil if it is deeply and thoroughly worked before planting. Give frequent and thorough but shallow cultivation until the tassels appear.

\section{SWEET OR SUGAR.}

EARLY CORY. This variety is the favorite for first early, and no other variety has proved earlier.

WHITE COB CORY. This is an improvement over the Early Cory, as the cob is white which gives it a finer appearance. It is as early as the Early Cory, and of excellent quality

MAMMOTH WHITE CORY. The ears are twelve rowed, fully twice the size of the old Cory, white cobbed, and covered with other wheet corn will find quality market which is supplied with Mammoth White Cory, and the gardener who wishes to get the cream of the trade should make his plantings of this splendid variety.

PREMO SWEET CORN. Premo can be planted fully as early as the Adams, for the young plants withstand slight frost, while other varieties are tender and the seeds will rot if planted before the soil becomes warm The stalks grow about five feet high, and are very vigorous, generally bearing two well developed ears to the stalk.

EXTRA EARLY ADAMS. This is an extra early field variety, but is much used as an arly market variety, being sweet and juicy.

EARLY MINNESOTA. One of the standweeks later than Cory or Chicago Market.

CHICAGO MARKET OR BALLARD. This is the largest and best early corn in ex-
istence, twelve rowed, white cobbed and of exceedingly fine quality. Crop failed.

CROSBY'S EARLY, An early corn of large size and choice quality. It has long a variety.

MOORE'S EARLY CONCORD. A well known early variety of large size, twelve a fine market corn.

ZIGZAG EVERGREEN. This fine new strain possesses the distinct characteristic which have made Stowell's Evergreen so produces ears fit to use from one week to ten days earlier.

OLD COLONY. This variety is two weeks earlier than the Evergreen, and almost as large. It is considered the best and sweetest by canning factories. A fine paying variety for market.

STOWELL'S EVERGREEN. The best late corn for all purposes It has been a leader for many years as a main crop variety, and is unexcelled as a market corn.

COUNTRY GENTLEMAN. This is the finest of the medium late varieties. The rows are zigzag, with a long slender kernel of delicious flavor. This corn is bound to sell when properly known, as its quality is the best of all.

MAMMOTH SUGAR. A large late variety having ears of mammoth size 14 to 20 rows. Quality excellent, not exceeded by any variety. A good canners' variety, being white grained and very uniform. A week later than Stowell's Evergreen.

BLACK MEXICAN. This corn, when in condition for the table, cooks remarkably white: but the ripe grain is black or bluish-black. It is surpassed by none in tenderness. For family use it is considered by many the most desirable of the medium late sorts. It does especially well for second early in the south.

\section{SWEET CORN PRICES.}

Early Cory

White Cob Cory

Mammoth White Corey.

Premo

Extra Early Adams

Early Minnesota.

Crosby's Early

Moore's Early concord.

Zig-Zag Evergreen.

old Colony

Stowell's Evergreen

Country Gentleman

Mammoth Sugar.

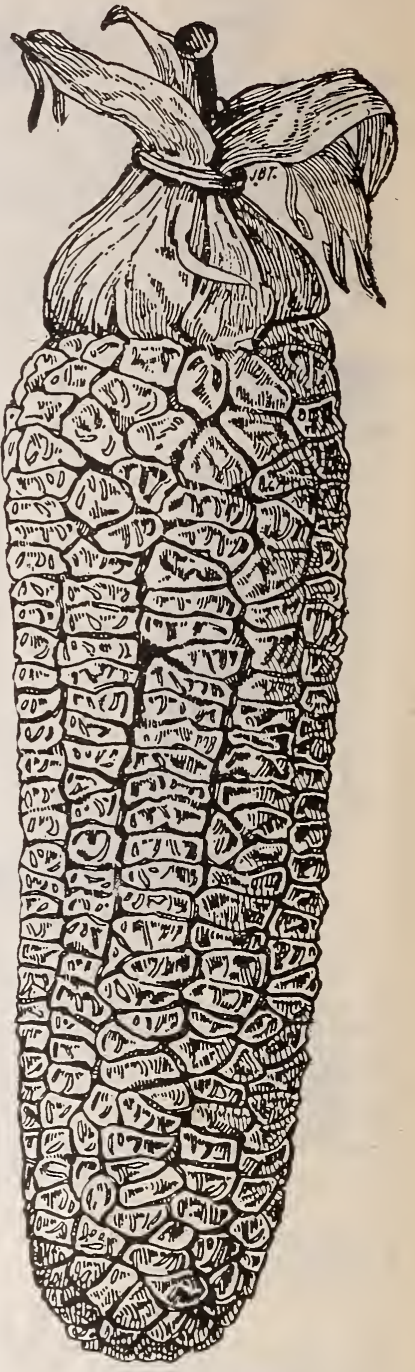

EARLY MINNESOTA. 


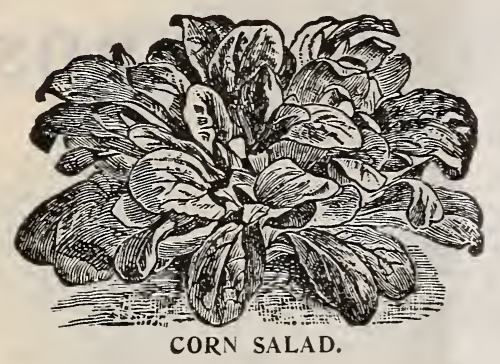

CRESS.

\section{CORN SALAD.}

FETTICUS, OR LAMB'S LETTUCE. This small salad is used during the winter and spring months as a substitute for lettuce, and is also cooked and used like spinnach. In warm weather the plants will mature in four to six weeks. Sow the seed in shallow drills about one foot apart, during August and September. If the soil is dry it should be firmly pressed over the seed in order to secure prompt germination. On the approach of severe cold weather, cover with straw or coarse litter. The plants will also do well if the seed is sown very early in the spring, and, like most salad plants, are greatly improved if sown on very rich soil; indeed, the ground can scarcely be made too rich for them. Pkt., 5c, oz. 10 c.

This page contains odd kinds, but each article makes a delicious veget able:

CURLED, OR PEPPER GRASS. This small salad is much used with lettuce, to the flavor of which its warm, pungent taste makes a most agreeable addition. The seed should be sown in drills about sixteen inches apart, on very rich ground, and the plants well cultivated. It may be planted very early, but repeated sowings are necessary to secure a succession. Keep off insects by dusting with Pyrethrum Powder. Pkt., 5c.; oz., 10c.

TRUE WATER. This is quite distinct from the last, and only thrives when its roots and stems are submerged in water. It is one of the most delicious of small salads, and should be planted wherever a suitable place can be found. The seed should be sown and lightly covered in gravelly, mucky lands, along the borders of small, rapid streams. The plants will need no subsequent culture, as under farorable conditions

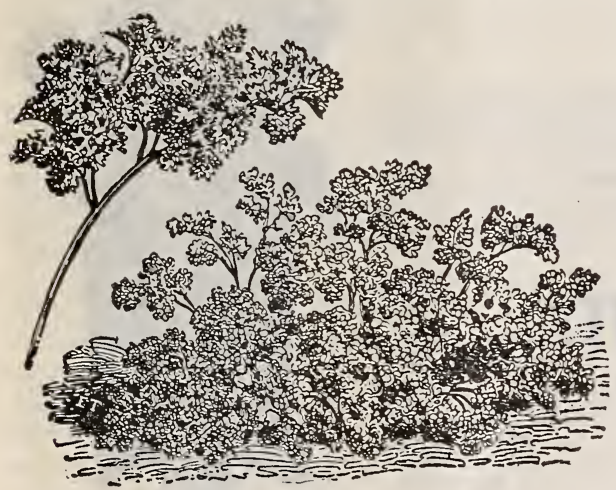

CHERVIL. they increase very sown seed and exPkt., 5c.; oz., 20c.

\section{Try These Odd Varieties.

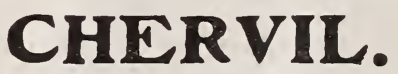

A hardy annual, worthy of more general use for flavoring and garnishing. The curled variety is even more beautiful than parsley, and can be used great advantage in beautifying dishes of meat and vegetables.

Culture. Sow in early spring in rich, well prepared soil, and when plants well established transplant to about one foot apart.

CURLED. Greatly superior to the old, plain variety, being earlier, more handsome, and having fully as fine perfume and flavor. Pkt., 5c.

\section{CHICORY.}

LARGE=ROOTED, OR COFFEE. Our stock is the improved type, with very much larger, smoother, whiter and proportionately shorter roots than the old kind. The dried and prepared roots are used quite extensively as a substitute or adulterant for coffee. Sow the seed as early in the spring as the ground can be prepared, in rather light, in the spring as the ground can be prepared, in rather light, moderately rich soil, in drills fifteen inches apart for garden, plants are sufficiently large, thin to four to six inches apart in the row. Keep clear of weeds, and in the fall dig the roots, slice them and dry in an apple evaporator or kiln constructed for the purpose. Where the roots are grown in quantity for the manufacturers of the "prepared" chicory, they are usually brought to the factory in the "green" state and there dried in kilns constructed for the purpose. Pkt., 5c.; oz., 20c.

\section{DANDELION.}

The dandelion is a hardy perennial plant, resembling endive, and affords one of the earliest and most healthiul sprins greens or salads. Sow early in spring in drills 12 inches apart, and thin out to 6 inches in the drills; the following spring it will be fit for use.

BROAD LEAVED. Pkt., 5c.

IMPROVED THICK LEAVED. An improved thickleaved variety. Pkt., 5c.

\section{EGG PLANT.}

IMPROVED NEWV YORK PURPLE SPINELESS. VerY large and smooth, fine dark color. Ours is the spineless plant, most preferred by our market gardeners, both east and west. We have made the most careful selection possible of our stock plants, and know it to be unsurpassed for the market. Pkt., 5c.

BLACK PEKIN. A fine variety, bearing large, round, deep, purple fruits fine grained, and of superior quality. Pkt.,5c.

EARLY LONG PURPLE. Early, hardy and productive; excellent for the table. Pkt., 5c.

Egg Plant is one of the best paying of all the garden crops. It is tender at the start, but anyone who will exercise care can grow it.

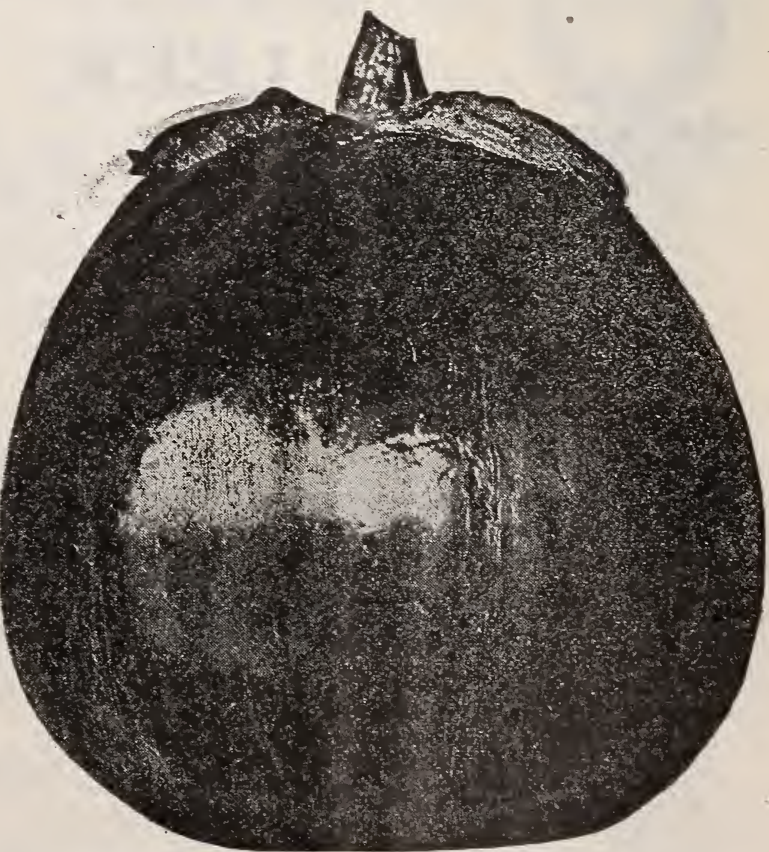

IMPROVED NEIV YORK SPINELESS EGG PLANT. 


\section{AROMATIC, MEDICINAL \& POT HERBS}

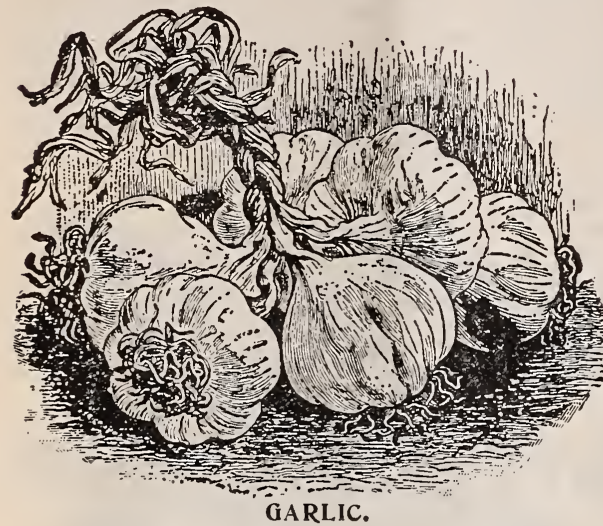

\author{
General Cultural Directions.
}

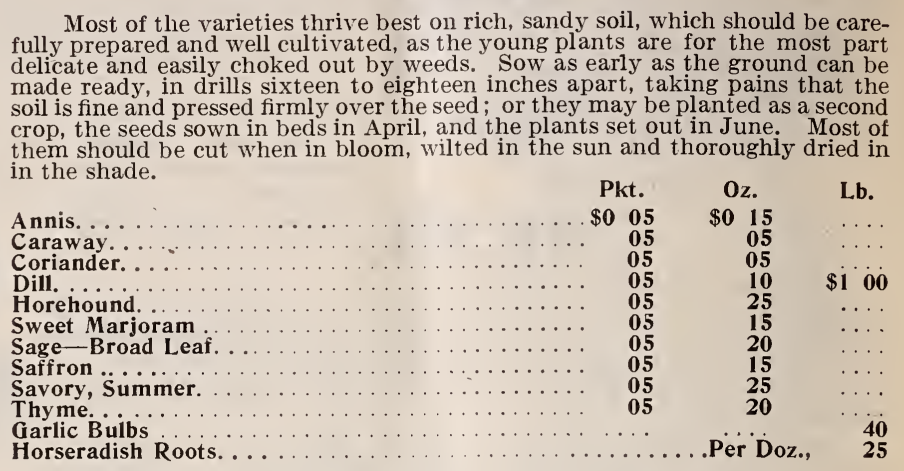

\section{KALE.}

One ounce of seed will sow a drill of about 200 feet.

SIBERIAN KALE, OR WINTER SPROUTS. This is also called German Greens and is sometimes sold for Dwarf Green Curled Kale, but it is not as curly as the Dwarf Curled Kale and is different from it in color. The leaves are smooth in the center, having a fringed edge. Color has a bluish tinge, not the deep green of the Dwarf Curled Kale. Pkt., 5c; oz., 10c.

DWARF GREEN CURLED GERMAN. Leaves yellowish green, very compact and beautifully curled; sow in September for winter and early spring use. Pkt., 5c; oz., 10c.

DWARF CURLED SCOTCH. Leaves bright green, curled, very tender and fine flavored; an excellent sort for private gardens. Oz., 10c.

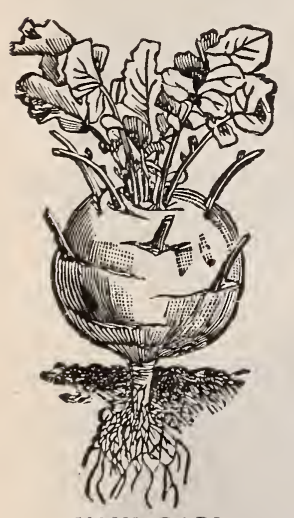

KOHL=RABI.

\section{KOHL-RABI.}

One ounce of seed will sow a drill of about 150 feet.

EARLIEST ERFURT. A white tender variety, with a smooth root and very short top; the best variety for outdoor culture. Pkt., $5 \mathbf{c} ; \mathbf{0 z}$., 15c. EARLY SHORT LEAVED WHITE VIENNA. The finest for market. Flesh white and tender. Pkt., 5c; oz., 15c.

EARLY PURPLE VIENNA. Bluish purple; similar to the above, except in color. Pkt., 5c.; oz., 15c.

\section{LEEK.}

LARGE AMERICAN FLAG. Large, hardy and of excellent quality. Pkt., 5c.; oz., 10c.

GIANT CARENTAN. The favorite market variety, large, thick stem, of mild flavor and attractive appearance. Pkt., 5c.; oz., $10 \mathrm{c}$.

MUSSËLBURGH'. Grows to a very large size, with broad leaves, spreading like a fan; hardy, of excellent quality. Pkt., 5c.; oz., 10c.

LONDON FLAG. An old and popular sort; one of the hardiest and best for winter use. Pkt., 5c.; oz., 10c.

\section{MARTYNIA.}

The Martynia, or Unicorn Plant, is quite ornamental in growth, quickly forming large bushes and bearing handsome gloxinia-like flowers. When young and tender the seed pods make excellent pickles, and as they are produced in great abundance, three or four plants will suffice for an ordinary garden.

MARTYNIA PROBOSCIDEA. The best variety for pickles. Pkt., 10c

\section{ENDIVE.}

One of the most refreshing and attractive of all autumn and winter salads. Sow seed from the middle of June until the end of August.

Ger., Endivien. Fr., Chicoree. SP., Endivia.

GREEN CURLED. Beautifully curled, tender and crisp. Pkt., 5c.; oz., 10c. MOSS CURLED. More finely curled, and a heavier and more dense plant than Green Curled. Pkt., 5c.; oz., 10c.

WHITE CURLED. V̈ery tender when cut young; blanches readily. Pkt.,

BROAD=LEAVED BATAVIAN. (ESCARROLE.) This variety is cliefly used in soups and stews; requires to be tied up in blanching. Pkt., 5c.; oz., 10 c.

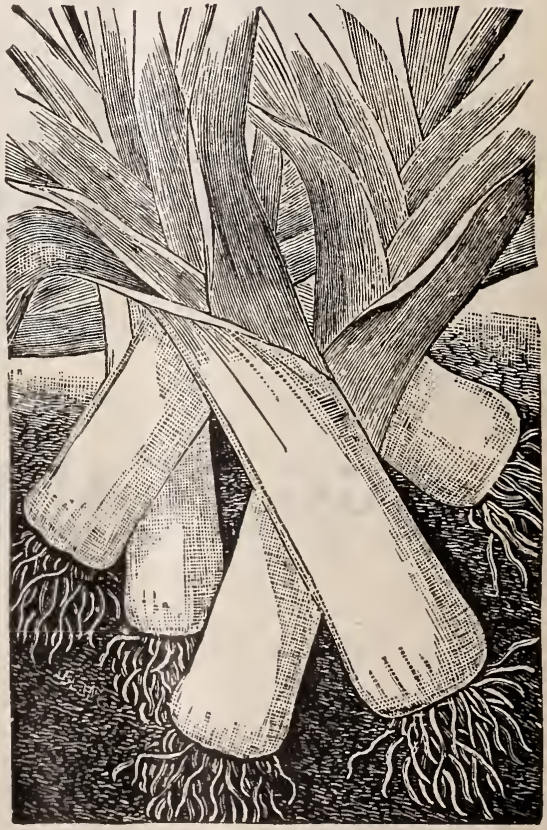

LEEK-MUSSELBURGH. 


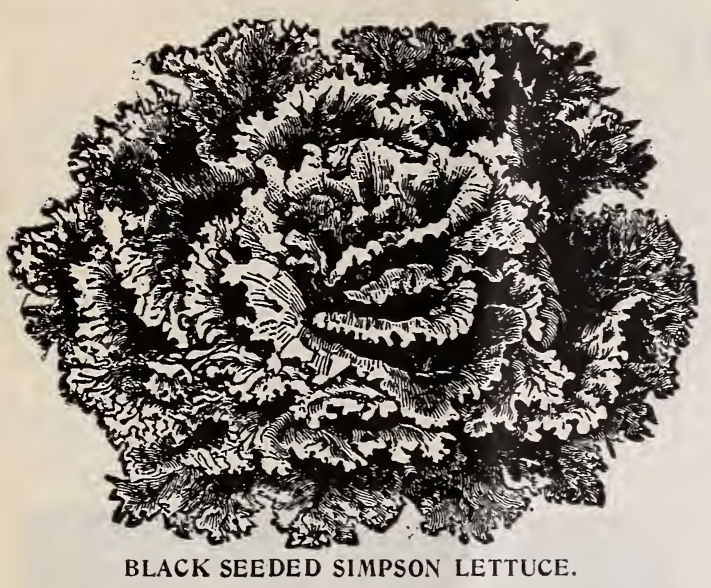

BLACK SEEDED SIMPSON LETTUCE.

\section{LETTUCE.}

BLACK SEEDED SIMPSON. We have a fine strain of this lettuce carefully selected. This is the most popular sort on the market. Forms large, loose heads. Lea res thin and exceedingly tender, of light green to golden yellow. Best sort for forcing or outdoor early planting. Pkt., 5 c.; oz., $10 \mathrm{c}$.

EARLY CURLED SIMPSON WHITE SEED. Forms a close, compact mass of curly yellowish green leaves. Farlier than the head varieties. Good for cold frames or early planting for outdoors. Pkt., 5c.; oz., 10c.

GRAND RAPIDS FORCING. Preferred by a great many to the Black Seeded Simpson, on account of being a tougher leaved lettuce. This makes it a fine sort for shipping as it does not break so easily, and stands longer without wilting. Fine appearance and strong grower, and will not rot as quickly as other sorts. A quick grower. Pkt., 5c., oz., 10 c.

NEW YORK. Is of unusual size and solidity of head, with but little tendency to run to seed. We have had it, time and but little tendency to run to seed. We have had it, time and again, eighteen inches in diameter, and weighing nearly four pounds, with heads almost as solid as an Early Summer cabbage, blanches itself naturally, is crisp, tender and of excellent flavor. Pkt., 5c.; oz., 10c.

THE DEACON. A magnificent butter head lettuce. It stands the hot weather without becoming bitter or running to seed,

and bears fine, large heads of superb quality. Light green outside, and, within, a beautiful cream yellow of delicious, rich, buttery flavor. Highly recommended for home or market use. Pkt., 5c.; oz., 10c.

PRIZE HEAD. A good header. Solid and large. Pkt., 5c.; oz., 10c.

CALIFORNIA CREAM BUTTER. A grand, good butter lettuce. The heads are of good size, round and solid; outside, medium green; within, the leaves are a rich cream yellow color. Rich and buttery in taste. Pkt., 5c.; oz., 10c.

BIG BOSTON. This rariety is identical in color, shape and general appearance with the famous Boston Market lettuce, but is double the size. It is about one week later in maturing, but its solidity and greater size of head will make it a most valuable sort. A most desirable variety, either for forcing in cold frames or open ground planting. The Big Boston is sure to be wanted by market gardeners and trucksters, because it always produces large, solid, salable heads, and will commend itself to amateurs because it heads up well at all seasons of the year, and is of crisp, tender quality. Pkt., 5c.; oz., 10c.

HANSON. Heads very large, from two to three pounds each; hearts quickly and stands the summer well; quality excellent. Pkt., 5c.; oz., 10

WONDERFUL. Introduced four years ago and continually growing in favor. The large, white heads resemble cabbage in their solidity, and frequently weigh two and three pounds each. The quality is superb, being crisp rich and tender. It withstands the heat well, making a fine variety for all rich and tender. It withsta

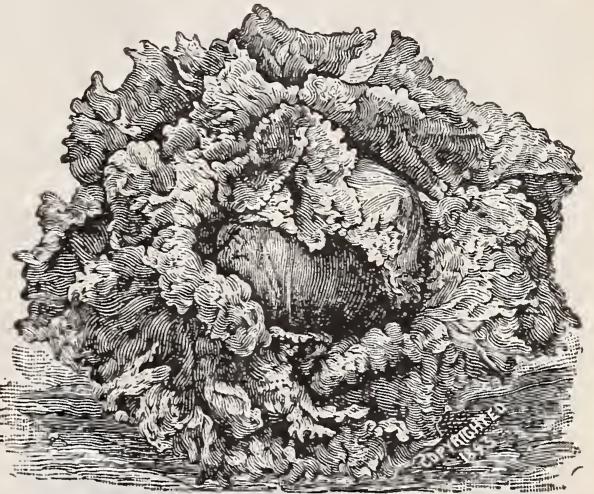

PRIZE HEAD.

There is no green vegetable more beneficial for toning up the entire system. Lettuce used as a salad either alone or as a mixed salad has no equal. Also for garnishing meats and side dishes there is nothing more effective. The ease with which it is cared for is also quite a consideration. Planted early and resown once or twice during the summer, one may have this excellent green vegetable through the entire season and at less trouble than almost any other variety.

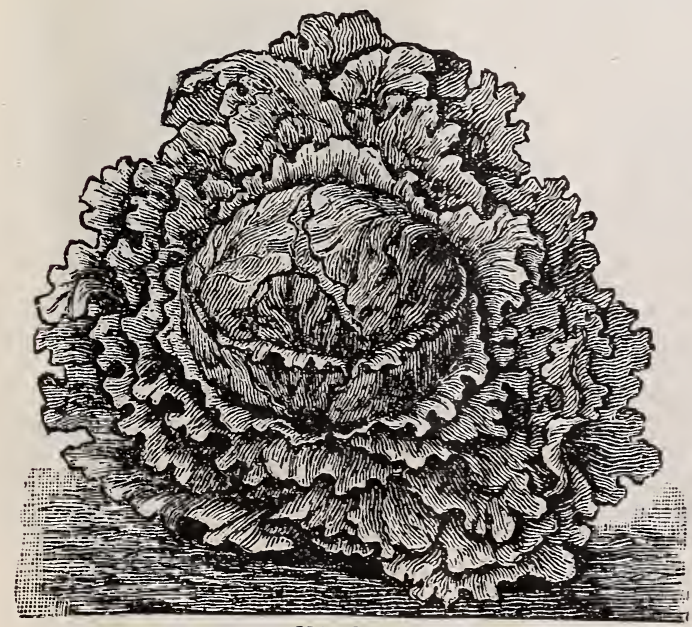

HANSON.
CHARTIER. It makes a tery large, firm head, almost as hard as a cabbage, is very tender and crisp and has a peculiar, fine flavor. It is of a beautiful green color, and the outer edges of the leaves are tinged with brown. It withstands the summer heat well, and is slow to run to seed. Pkt., 5c.; oz., 10c.

EARLY TENNIS BALL, WHITE SEED. A good early sort, and used largely by eastern gardeners for forcing. Pkt., 5c.; oz., 10c.

EARLY TENNIS BALL, BLACK SEED. A good lettuce for early use. The heads are small, but are very crisp and solid. Pkt., 5c.; oz., 10c.

EARLY CURLED SILESIA. A rery tender sort, with fine curled leaves. Pkt., 5c.; oz., 10c.

BOSTON CURLED, Curled leares of good quality, a popular variety among eastern growers. Pkt., 5c.; oz., 10 c.

DEFIANCE. Of a light green color, with the outer edge of the leaf slightly curled. Makes a large head. Pkt., 5c.; oz., 10c.

HUBBARD MARKET. A large heading variety, good for either forcing or sowing in open ground. Pkt., 5c.; oz., $10 \mathrm{c}$.

PARIS WHITE cos. The Cos lettuce differs entirely in shape from the other varieties, the head being elongated and of conical form, eight or nine inches in height, and five or six inches in diameter. The outer coloring of this variety is yellowish green. To be had in perfection it requires to be tied up to insure blanching. Millions of this variety are annually grown to supply the markets of London alone. Pkt., 5c.; oz., 10c.

ALL SEASONS. One of the best all head lettuces, standing the hot sun better than any other sort. Slow to seed. Handsome, enormous size; color, light green. Pkt., $5 \mathrm{c}$.; oz., 10c.

DENVER MARKET. This is a fine crisp, crimpled head variety.

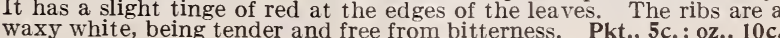




\section{MUSK MELON.}

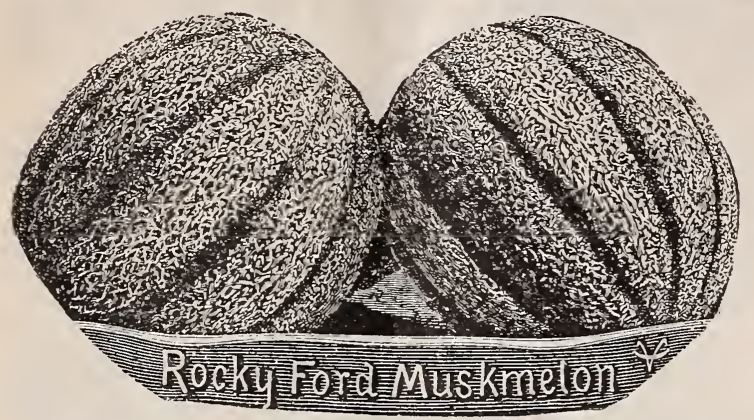

GREEN FLESHED OSAGE. Quality of the best; flesh a beautiful pea green; aiso a good shipper. Pkt., 5c.; oz., 10c.

EARLY HACKENSACK. A green fleshed nutmeg, of excellent form. A very early and splendid melon. Pkt., 5c.; oz., $10 \mathrm{c}$.

HACKENSACK. A large, deeply netted melon, flattened at the ends, of most delicate flavor and very productive. Pkt., 5c.; oz., 10c.

CHAMPION MARKET. Shape almost round, deeply ribbed skin heavily netted; flesh light green, rich and sweet. Very productive, and nearly as early as the Netted Gem. An excellent shipping variety. Pkt., 5c.; oz., $10 \mathrm{c}$.

CHICAGO MARKET. Fruit large, round or slightly oval, with very shallow depressions and covered with dense netting. Flesh green, medium texture, very thick and sweet. The variety is an im-
provement on Montreal, and will suit those who like a large, sweet, provement on Montreal, and will suit the
green fleshed sort. Pkt., 5c.; oz., 10c.

PAUL ROSE. A new sort, possessing several characteristics of the Osage; form slightly oblong, distinctly ribbed, slightly netted color, when unripe a deep green, turning a golden tint; flesh salmon, and so thick as to show an unusually small seed cavity; flavor like Osage. A showy variety. Pkt., 5c.; oz., 10c.

BANQUET. A medium sized variety, nearly round, flattened at the ends, densely netted; flesh dark salmon, uniformly thick; flavor unsurpassed, rivaling the Netted Gem. Pkt., 5c.; oz., 10c.

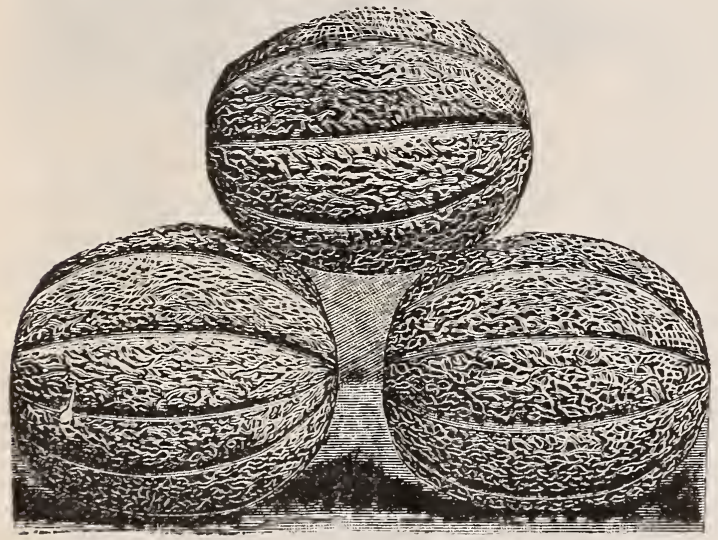

PAUL ROSE MUSK MELON.

OSAGE, OR MILLER'S CREAM. A remarkably fine variety, and a very profitable sort for market gardeners, as it is fully established as a standard sort and will ever remain so. It is of medium size, oval in form, dark green in color, handsomely netted and slightly ribbed. The flesh is extremely and uniformly thick, of firm texture, rich salmon in color; highly flavored and delicious to the rind. Cavity very small.
good shipping melon. Pkt., 5c.; oz., 10c.

EMERALD GEM MELON. The Emerald Gem is entirely unlike any other musk melon yet introduced. The melons are about the size of the Netted Gem, but, unlike that variety, the skin, while ribbed, is perfectly smooth, and of a very deep emerald green color. The flesl, which is thicker and ripens thoroughly to the thin green rind, which is distinctly defined. The flesh is peculiarly crystalline in appearance, and so very juicy, sweet and rich that it almost drops to pieces. It matures very early, and is quite productive. Pkt., 5c.; oz., 10c.

\section{MUSHROOM SPAWN.}

\section{For the money invested, no more profitable crop. Once started,} easy to continue.

ENGLISH. 1 lb. Bricks, 25 c., 5 for $\$ 1.00$.
ROCKY FORD. This new musk melon is similar to the oval The melons grown by them are so fine in quality as to
all others, and the demand for sucl melons has been far

KILLMAN'S NETTED. An excellent early melon, with fine

BAY VIEW. A large prolific and fine flavored green fleshed cultivation this variety has produced melons weighing

ETTED GEM. The best early melon known. Shipped to ENNY LIND. A good early melon. Pkt., 5c.; oz., 10c.

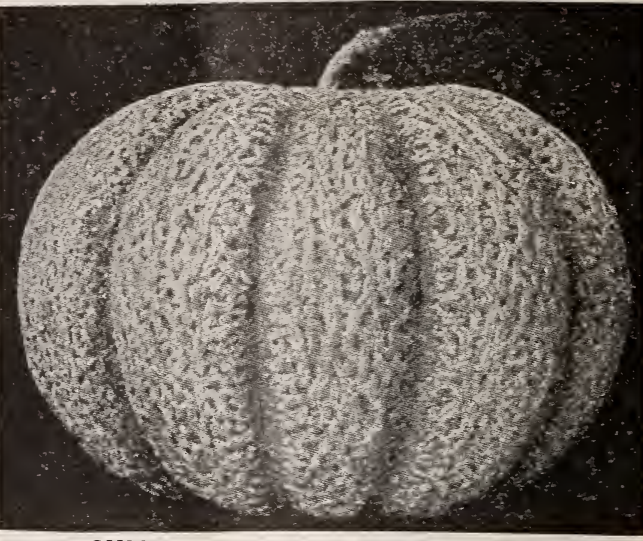

CHICAGO MARKET MUSK MELON.

TIP TOP. A new melon of recent introduction and very de-

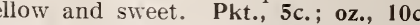

URPRISE. This old variety is still highly esteemed. Fruit (andy round, but slightly lobed and netted. Skin yellowish

DELMONICO MUSK MELON. A new oral-shaped musk melon of large size, finely netted, and has beautiful orange-pink cellence.

THE PRINCESS. This new melon is one of the best for the home garden. In shape it is nearly round, with heavy netted duscious The to ten pounds. The rines grow rigorously and are rery We can fully recommend The Princess to market their home markets, and to all who desire

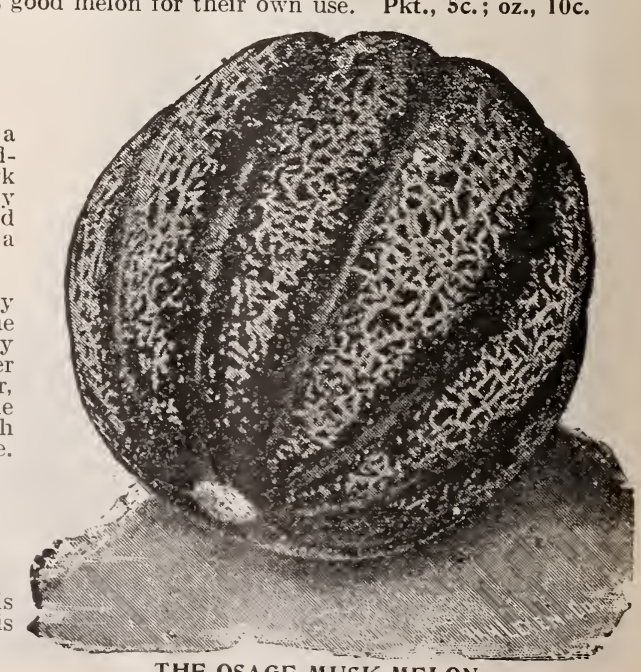




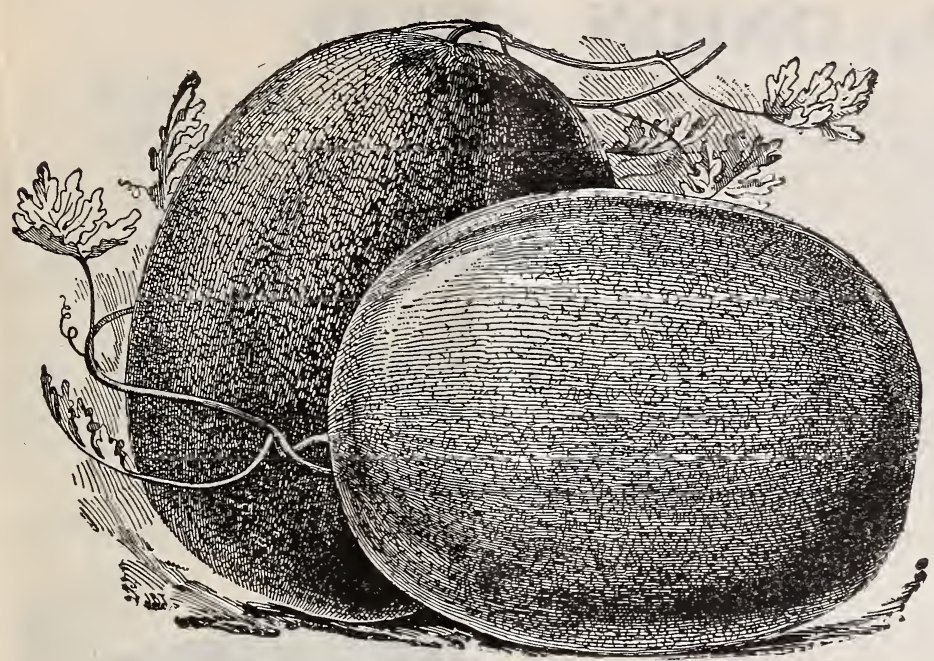

SWEETHEART WATER MELON.

\section{WATER MELON.} SWEET HEART WATER MELON.

This new melon is early, large, handsome heavy and productive. The shape is oval and the color mottled light to very light green. sweet. We have a very fine stock grown from selected stock seed procured from the originator, hence it is as pure and true as the original. Oz., 5c.

BLACK SPANISH. Large, roundish, nearly black; dark red flesh; early. Oz., 5c.

FLORIDA FAVORITE. A very large, long melon mottled dark green with stripes of lighter shade. Rind thin but firm - flesh very bright, deep red, very sweet, tender and excellent. A
very popular variety in the south. Oz., 5c. COLE'S EARLY. Very hardy, a sure cropper and extremely delicate in texture of flesh per and extremely delicate in texture of flesh, tremely brittle, hence not desirable for shipping purposes, but possessing all the other most desirable features. We highly recommend it for home use. Medium size, nearly round; rind
green striped with lighter shades. Oz., 5c.

DIXIE. A popular market sort, vine vigorous, large growing and hardy; fruit medium sized to large, about one-third longer than lighter shade rind, thin but tough; flesh bright scarlet, ripens closely to the rind, is of the best quality and free from the hard, coarse center which is so objectionable a feature of many shipping melons. Oz., 5c.

PHINNEY'S EARLY. Few, if any, of the early sorts of recent introduction surpass this old favorite. It is first to ripen, of good size and productive; shape oblong; rind a distinct mottled color; the flesh is a deep red; a first class early market melon. Pkt., $\mathbf{5 c}$.; oz., 10c.

VICK'S EARLY. This variety is prized for its earliness. It is oblong in shape, smooth, with a very dark skin, rather small in size, flesh bright pink, solid and sweet. It makes a good extra early market or home garden melon. Oz., 5c.

SEMINOLE. An exceedingly productive, extra early variety, of large size. Fruit oblong in shape, flesh solid, ripening clear up to the rind, vivid crimson, crisp, sugary and of delicious flavor. Oz., 5 c.

GYPSY, OR GEORGIA RATTLESNAKE. One of the largest varieties and stands shipment long distances. Fruit cylindrical, square at the ends, smooth, distinctly striped and mottled light and dark green. Flesh bright scarlet and very sweet. Oz., 5 c.

TRIUMPH. A new southern variety. The fruit is uniformly large, nearly round, dark green, indistinctly striped with a lighter shade; rind thin and firm,
making it an excellent shipper. Flesh bright red and of good quality. 0z., 5c.

BOSS. Early and very large; a good shipper, 0z., 5c.

ICE CREAM. Medium sized with very sweet, scarlet flesh. A good variety for main crop. 0z., 5 c.

KOLB'S GEM. Vines of medium size, but remarkably vigorous and healthy. Leaves of medium size, deeply cut with a peculiar frilled edge Fruit of the Leaves of medium size, deeply cut with a peculiar frilled edge. Fruit of the and light green. Outer rind or shell exceedingly hard and firm, making it a good sort for shipping long distances. Flesh bright red, solid, a little coarse, but sweet and tender. Oz., 5 c.

\section{ONION SETS.}

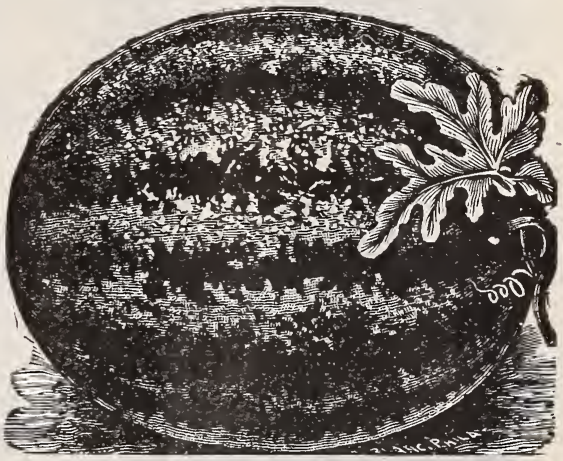

KOLB'S GEM.

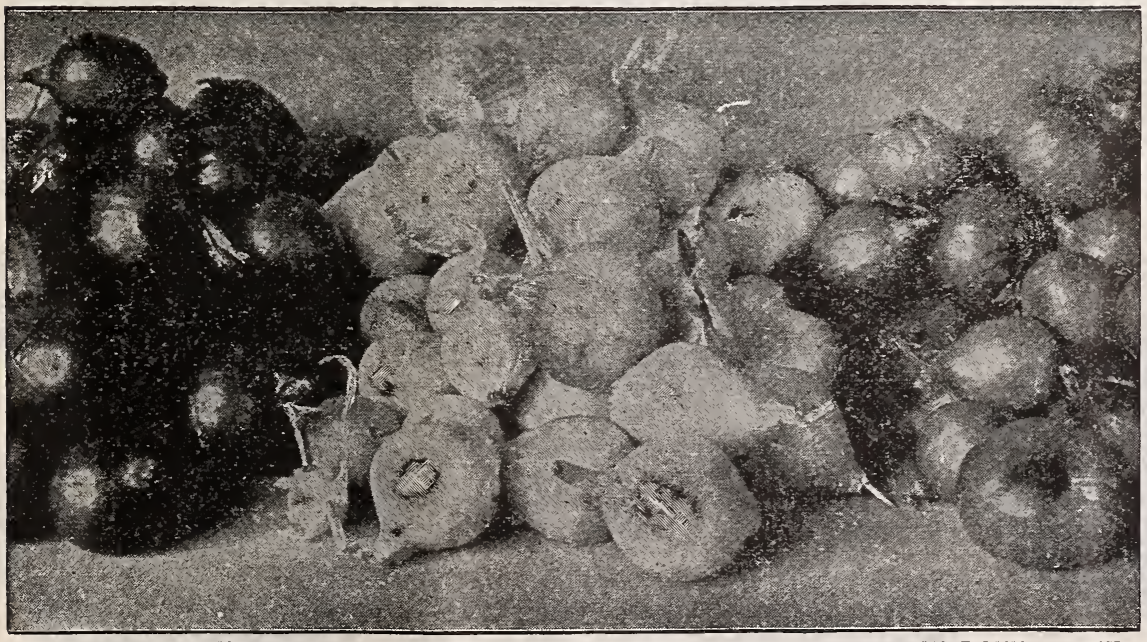

RED BOTTOM SETS.

WHITE BOTTOM SETS.
YELLOW BOTTOM SETS.

Red Bottom Sets. $\$ 0$ io $\$ 020$ White Bottom Sets $10 \quad 20$ Yellow Bottom Sets $10 \quad 20$ $\begin{array}{lll}\text { Genuine Top Sets. . } & 15 & 30 \\ \text { Winter Top Sets. } & 10 & 20\end{array}$ Potato Onions.... $15 \quad 25$ White Multipliers. . 15 25 Yellow Muitipliers . 15

Onion Sets should be plant= ed as early in the Spring as convenient, to obtain early green onions, but they may be set at any time up to June 1 st. Set in rows a foot apart and three to four inches be= tween them in the row. Any good soil will suit them. When grown in quantity, high cultivation is given in order to forward the crop for an early market. They are ready for use as soon as the bulbs begin to be of fair size. Those not used in green condition will ripen early in July and make nice Onions. Potato and Top Onions are Potato and Top Onions are
grown from bulbs only, growing in clusters. These clusters are separated and the smaller ones kept for seed. There is no crop which pays better than the first load or so of green onions in the market. Onion Sets will make this crop for you. Why not grasp the opportunity offered? Our Sets onions for home use at a time when a fresh green vegetable is needed. 


\section{CHOICE ONION SEED.}

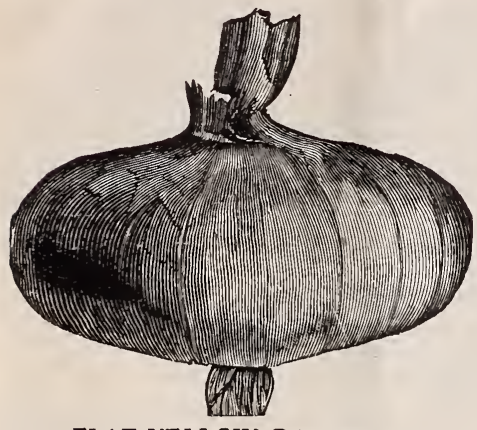

FLAT YELLOW DANVERS.

$\checkmark$ EARLY FLAT YELLOW DANVERS. A good variety, but not as round or quite as early as the Yellow Globe Danvers. Very productive.

YELLOW STRASBURG, OR DUTCH. One of the oldest varieties. Bulbs quite flat, of good size, skin yellow, flesh white, of mild flavor, and keeps well. This is the variety that formerly was used very extensively for growing yellow onion sets, and while still good for that purpose, it has of late years been nearly superseded by the Yellow Danyers.

D AUSTRALIAN BROWN ONION. Is of medium size, wonderfully hard and solid, and most attractive for market, both as to form and appearance. The color of the skin is a clear amber brown. So widely contrasted from any other onion is this color that it will be noticed on the market, and when once bought, purchasers will be likely to return and gall again for "those beautiful brown onions."

PRIZETAKER. Grows to an immense size and for fall marketing is unexcelled. Handsome bulbs of a rich yellow color and fine globe form.

YELLOW GLOBE DANVERS. This fine onion is of large size. An early and abundant cropper. Bulbs very thick, flat or slightly convex bottoms, full oval top with small neck and rich brownish yellow skin.

SOUTHPORT YELLOW GLOBE. A large, perfectly shaped Globe onion and an excellent onion for keeping throughout the winter. A very heavy cropper, handsome in appearance and good dark yellow color.

LARGE RED WETHERSFIELD. We have a very fine and select strain of this sort. Color is deep purplish red, flesh white, moderately grained and very firm. Yields an enormous amount per acre, and is one of the best winter keeping onions.

EXTRA EARLY FLAT RED. This variety matures from ten days to two weeks earlier than the Red Wethersfield. The color is a deep rich red, fine grain and close. The onion is solid and heavy and is a fine sort where the seasons are cold and short.

SOUTHPORT RED GLOBE. This is a fine keeper. Large size and considered one of the best red onions. Flesh is fine grained, very mild and tender.

WHITE PORTUGAL. American Silver Skin. This is the best sort to sow-for onion sets or for pickling. When sown thickly for either it makes a small, round, hard bulb. When grown for large onions they are very flat in shape and mild and pleasant in flavor.

PHILADELPHIA SILVER SKIN. Very desirable for family use. Flavor mild and pleasant. Skin silvery white. Sets grown from this sort are the best keepers.

SOUTHPORT WHITE GLOBE. This grows to a very large size and is a perfectly globe shaped onion. Color is a clear pure white. This variety is used by the Chicago market gardeners entirely for bunching. A fine keeper.
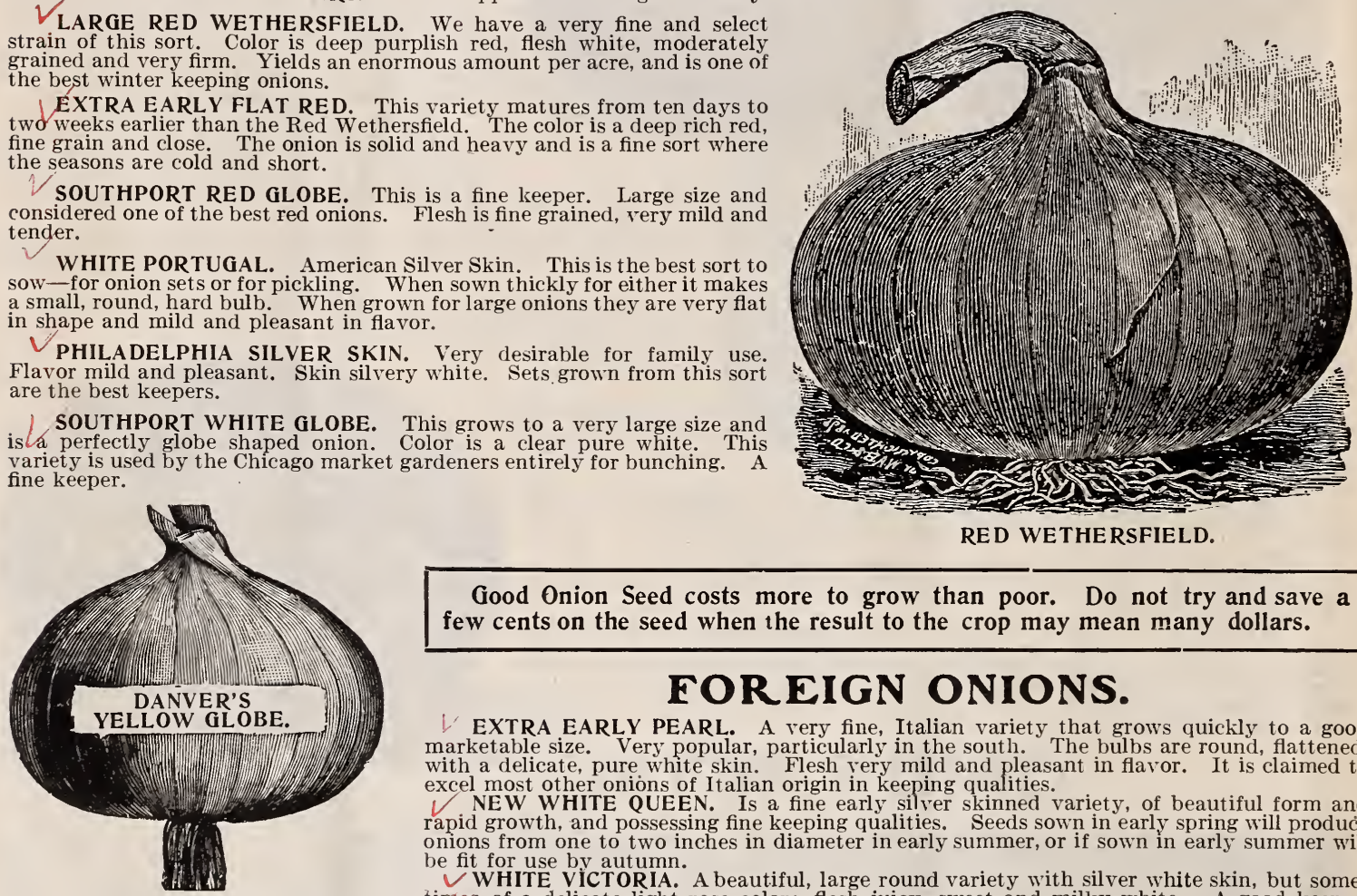

RED WETHERSFIELD.

Good Onion Seed costs more to grow than poor. Do not try and save a few cents on the seed when the result to the crop may mean many dollars.

\section{FOREIGN ONIONS.}

EXTRA EARLY PEARL. A very fine, Italian variety that grows quickly to a good marketable size Very popular, particularly in the south. The bulbs are round flattened, with a delicate, pure white skin. Flesh very mild and pleasant in flavor. It is claimed to with a delicate, pure white skin. Flesh rery mild and pleasant

excel most other onions of Italian origin in keeping qualities. rapid growth, and possessing fine keeping qualities. Seeds sown in early spring will produce onions from one to two inches in diameter in early summer, or if sown in early summer will be fit for use by autumn.

$\checkmark$ WHITE VICTORIA. A beautiful, large round variety with silver white skin, but sometimes of a delicate light rose color; flesh juicy, sweet and milky white. A good keeper. WHITE BARLETTA. When matured, the tops die down, leaving beautiful and perfect ittle bulbs. The color is pure white, flavor mild and delicate, perfectly adapted for pickling and table use, and makes a pretty bunch onion, especially if grown by the transplanting methorl.

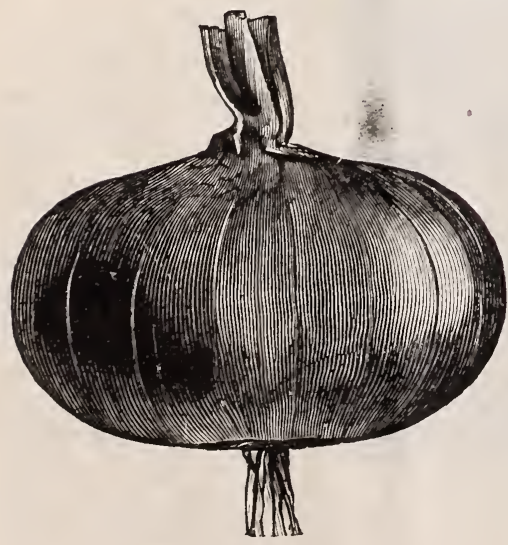

Prices of Foreign Onions, Pkt., 5c;0z., 10c; $\frac{1}{4}$ lb., 30c.

\section{ONION PRICE LIST.}

A ustralian Brown

Early Flat Yellow Danvers

Yellow Dutch or Strasburg

Prizetaker. .

Yellow Globe Danvers. .

Southport Yellow Globe

Southport Red Globe. . .

Large Red Wethersfield .

Extra Early Flat Red

Southport White Globe

WHITE PORTUGAL.
Pkt.

\$0 05

05

05

05

05

05

05

05

05

05

05

05
White Portugal .

Philadelphia Silver Skin
Oz.

\$0 15

15

15

15

15

15

15

15

15

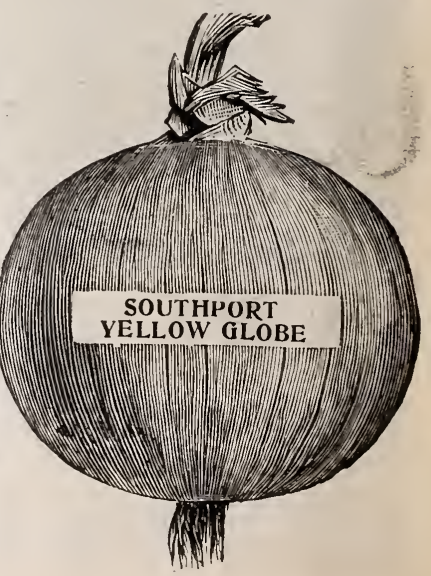




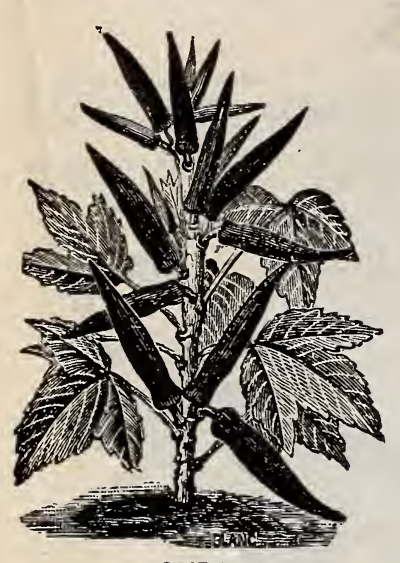

OKRA.

\section{OKRA OR GUMBO.}

This vegetable is too little grown, as its green pods impart a fine flavor and consistency to soups and stews; the pods can also be dried for winter. It is universally used throughout the south, and is as easily raised in the north. So delicious is the flavor that when once used it will be grown every year.

LADY FINGER. The plants are uniform in growth, and with their large hibiscus-like flowers make a pretty sight. The plants produce long, slender pods. Oz., 5c.

DWARF PROLIFIC OR DENSITY. A fine new variety, much dwarfer than the ordinary dwarf okra, and much more productive. Short, thick pods. Oz., 5c.

WHITE VELVET OKRA. The pods are perfectly round, smooth and of an at tractive white velvet appearance; of superior flavor and tenderness. Oz., $\mathbf{5 c}$.

TALL GREEN. A favorite at the south; called also Perkins Mammoth Long Pod. Oz., 5c.

DO NOT FAIL TO TRY OUR FINE PEA, DUKE OF YORK, shown on next page ONCE USED NO OTHER WILL SUFFICE.

\section{PARSNIP.}

\section{FO R F L OW E R SEE DS SEE \\ PAGES 24 TO 27.}

LONG WHITE DUTCH, OR SUGAR. Roots very long, white, smooth, tender, sugary and of most excellent flavor. Very hardy, and will keep through winter without protection. Oz., 5 c.

HOLLOW CROWN. Roots comparatively short, with a very smooth, clean skin. The variety is easily distinguished by the leaves arising from a depression on the top of crown of the root. Oz., 5 c.

GUERNSEY. The best sort for heary, black soils. In the vicinity of Chicago, where the soil is exceedingly rich, this is the rariety needed, as it makes a fine shaped root which does not grow too long. Oz., 5 c.

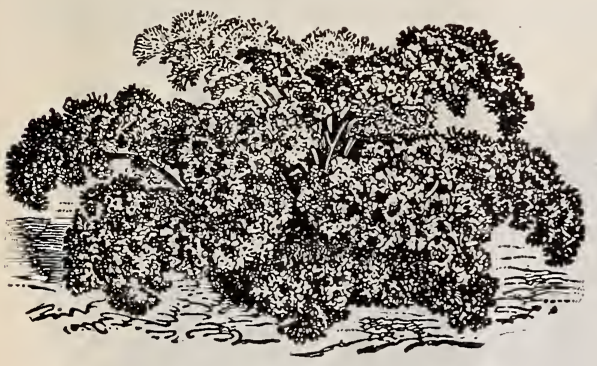

CHAMPION MOSS CURLED.

\section{PARSLEY.}

FERN LEAVED. This sort has a peculiar, fern shaped leaf. It is not so desirable as the more curled sorts. Oz., 5c.

HAMBURG ROOTED. The standard rooted sort. The leaves are used for soup greens, and the roots, when sliced, are much esteemed. Oz., 5c.

DOUBLE CURLED: Th $\mathrm{e}$ standard sort for outdoor culture, also highly prized by market gardeners for the greenhouse.
$\mathbf{0}$ z., 5c.

CHAMPION MOSS CURLED. A very fine curled variety. One of the handsomest for garnishing purposes. The exceedingly curled leaves make it desirable. Oz., 5c.

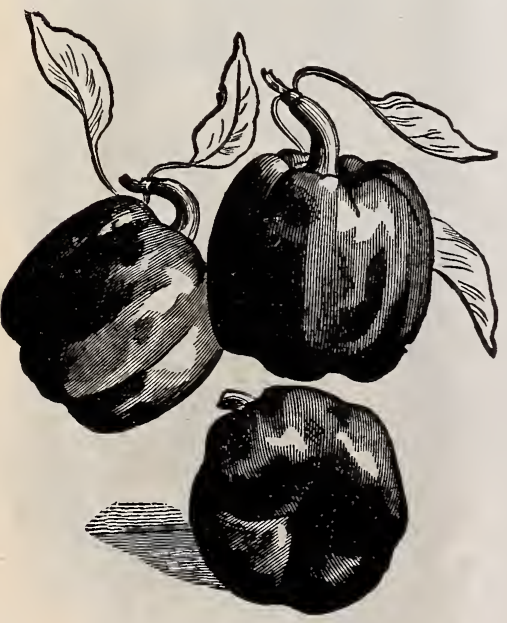

\section{PEPPER.}

SWEET MOUNTAIN. Plants very vigorous and productive, growing upright, with moderately large leaves. Fruit very large, long, often 8 inches or more in length, by two in diameter, very smooth and handsome, being, when unripe, of a bright deep green color, entirely ripe, of a bright deep green color, entirely free from any purple tinge, and when sweet and mild flavored. Well suited to use as a stuffed pickle. Pkt., 5c.; oz., 15c.

LARGE BELL, OR BULL NOSE A very large sort of inverted bell shape, suitable for filling or for a mixed pickle. Flesh thick, hard and less pungent than most other sorts. Pkt., 5 c.; oz., 15 c.

PROcopp'S GIANT.Very large, usually 8 to 9 inches long and 3 inches thick. Brilliant scarlet color, flesh thick, of pleasant flavor. Pkt., 5c.; oz., 15c.

RUBY KING. An improved American sort, reaching the largest size, yet retaining the symmetrical shape of the smaller sorts. Pkt., 5c.; oz., 15c.

LARGE SOUASH. Fruit large, flat, tomato shaped more or less ribbed, skin smooth and glossy, fiesh mild, thick meated and pleasant to the taste, although possessing more pungency than the other large sorts. Pkt., 5c.; oz., 15c.

GOLDEN UPRIGHT. The fruits are large and of a beautiful rich golden yellow, inged with a blush red. The peppers are mild and as pleasant to the taste as Ruby King. Pkt., 5c.; oz., 15 c.

RED CHERRY. Plant tall, bearing a profusion of bright red, round fruit which is very pungent when ripe. The plant is very handsome and an ornament to the garden. Pkt., 5c.; oz., 15c.

RED CHILI. Used in the manufacture of pepper sauce. Pods sharply conical, and exceedingly pungent when ripe. Requires a long, RE chts., 5c.; oz., 15c.

YELLOW CHILI. Similar in form to the Red Chili; more pungent, and of a very beautiful yellow color. Pkt., 5c.; oz., 15c.

LONG RED CAYENNE. A long, slim, pointed pod, and when ripe, of a bright red color. Extremely strong and pungent. Pkt., 5c.; oz., 15c. 


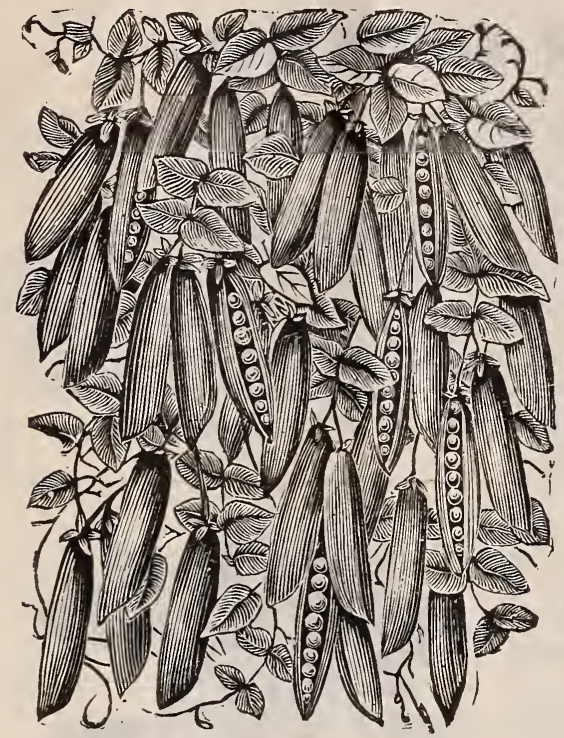

ALASKA PEAS.

HEROINE. Vines are strong and vigorous and produce an abundance of fine, large, well filled pods.

HORSFORD'S MAR = KET GARDEN. A great favorite with the market gardeners. Pods are large, well fllled and of a very good color: an abundant yielder.

EARLY FAVORITE i somewhat taller in vine than American Wonder o Nott's Excelsior, consequently in the average garden it shows up better, making the grower feel that there will be some peas from the patch. It pods better than any of the real dwarf wrinkled sorts, and equals any of them in quality.

DWARF TELEPHONE. A splendid dwarf pea. The pods are very long, and are always well filled with peas of delicious flavor. Height of vine under high culture, 18 inches. It may be classed as a medium early pea.

\section{PRICE LIST OF PEAS.}

Alaska

First and Best of $\mathrm{A}$ il

Maud S.

Tom Thumb.

Duke of York

Advancer.

Bliss Abundance.

Heroine

Horsford.

Early Favorite.

Dwarf Telephone

Champion of England

Duke of Albany.

Gradus or Prosperity .

Everbearing

Shropshire Hero

English Wonder

American Wonder.

Extra Early Prem, Gem

Little Gem.

Nott's Excelsior.

Telephone

Telegraph.

Sharpe's Queen

Black Eye Marrowfat.

Large White Marrowf at

Yorkshire Hero

Pride of Market.

Stratagem

Imported Sugar Marrow

Juno.

Long Isiand Mammoth.

\section{PEAS.}

ALASKA. The best early green seeded variety. The dark green color of the pods makes it an excellent pea for shipping long distances. Very early and uniform grower. A popular sort with canners and shippers. First-class in every respect. Height, $2 \frac{1}{2}$ feet.

FIRST AND BEST OF ALL. Ahead of all others in earliness and productiveness. It has held the lead for many years on the Chicago market, and is the best first early variety for the market gardener. It is very prolific, and ripens so uniformly that the vines can be cleaned at one picking. The most hardy.

MAUD S. A very fine extra early sort, hardy, productive and of good flavor.

TOM THUMB. Early and prolific. An ex-

\section{DUKE OF YORK. A variety that excels} all others for the market. This pea is not a novelty, but has been on the market for a number of years, although not as well known as some others.

It can be classed wit

the Telephone, al-

$\mathrm{th}$ o $\mathrm{uhh}$ it is much earlie

dwarf.

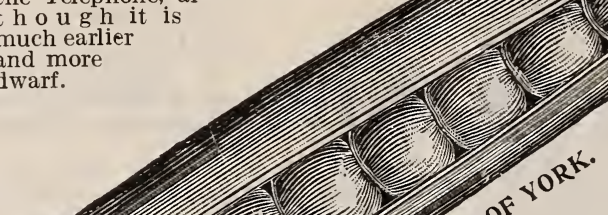

, and that the Duke of York fills a long-felt want in a medium early pea. ADVANCER. An old favorite with the market gardener. Quality excellent, very productive and easily picked.

BLISS ABUNDANCE. Vigorous in growth nce, hence the name. Pods well filled with large peas of very fine quality. 


\section{PEAS.-Continued.}

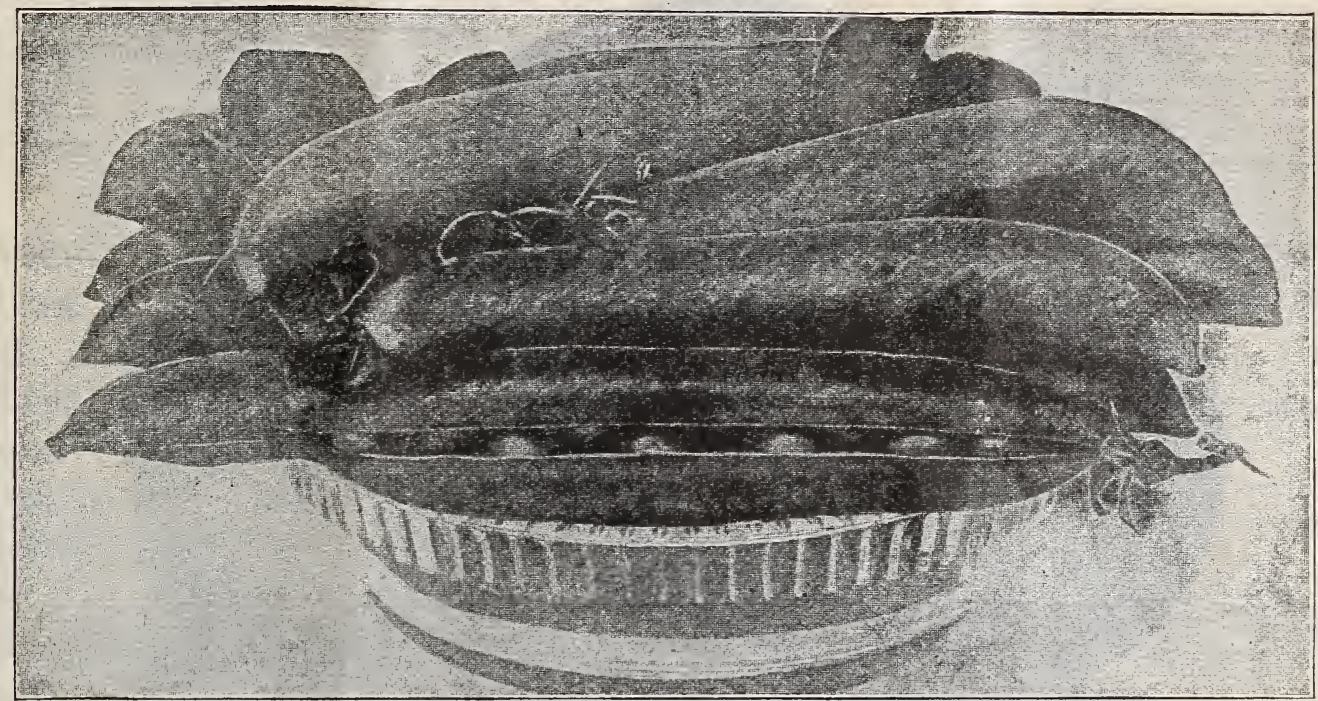

CHAMPION OF ENGLAND.

CHAMPION OF ENGLAND. For many years this has been one of the standard large late wrinkled sorts. In quality few rarieties equal it. Its greatest drawback as a market variety is its tall vines, which invariably need brush, and gardeners find this too expensive. For home use, however, it is unexcelled.

filled.

DUKE OF ALBANY. Like Telephone but a better variety. Vines are dwarfer and stronger and pods are larger and better

EVERBEARING. Fine for family use. Peas large and sweet.

SHROPSHIRE HERO. Bearing a great abundance of large handsome porls makes this a most desirable sort. Pods long, well filled and peas of fine flavor.

ENGLISH WONDER. About ten days later than the American Wonder and much longer, straighter and broader pods. Peas large and of fine flavor.

GRADUS OR PROSPERITY PEAS. This extra early pea is unsurpassed in quality, being the greatest advance yet made in the extra early peas, the pods very closely resembling the Telephone in size and shape, and containing from six to eight peas of excellent flavor. Ripening very quickly, the peas can be picked at one time, making it a valuable crop for the market gardener. In habit

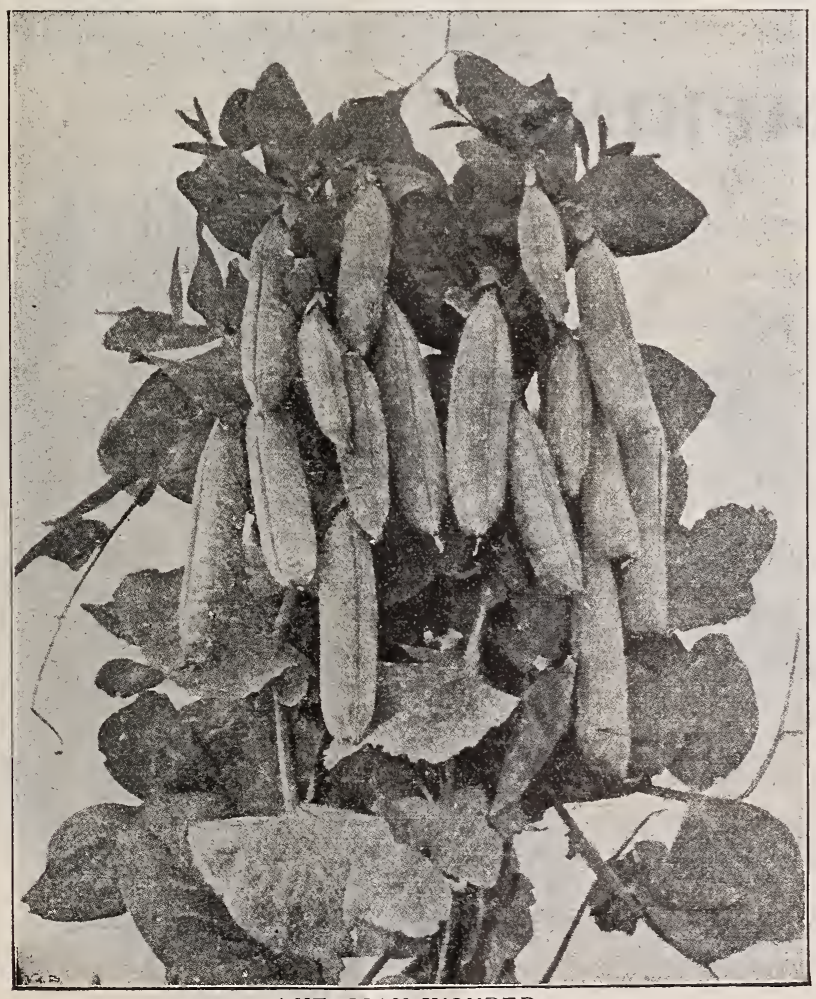

AMERICAN WONDER. it is vigorous, very quick to germinate and push to maturity, foliage large, pale green in color; pods long, wrinkled cream color; height, three feet.

AMERICAN WONDER. Vigorous, productive, with dark, luxuriant foliage. The most desirable early pea for private gardens. Height, fourteen inches. Of very fine quality.

EXTRA EARLY PREMIUM GEM. Extra early in season. The most productive of the dwarf wrinkled varieties, and for this reason is the best for market gardeners.

LITTLE GEM. Extra early, hardy and productive. Pods not so well filled as Premium Gem.

NOTT'S EXCELSIOR. Pods fully one-third larger than American Wonder, containing six to eight large sweet peas.

TELEPHONE TRUE STOCK. Gardeners prefer this pea to any other. Our stock this year has been carefully selected. Vines and leaves are large and coarse. Long, straight pods filled with large, tender coarse. Long, straight por
sweet peas of fine flavor.

SELEGRAPH. Strong, hardy vines, and peas
TELA very large and sweet.

SHARP'S QUEEN. Large, handsome, delicious. Pods long, slightly curved.

BLACK=EYED MARROWFAT. An old standard market variety. Not so sweet as the wrinkled peas but more hardy.

LARGE WHITE MARROWFAT. A fine rariety for soups, used in a dry state. Peas are large, smooth

YORKSHIRE HERO. Sinilar to Champion of England but the vines are not so tall.

PRIDE OF THE MARKET. A good main crop variety. Peas are large and sweet.

STRATAGEM. Vigorous, habit luxuriant foliage. A heavy cropper. A general favorite not only in private gardens but also for gardeners. Large, handsome pods well filled. One of the most desirable sorts.

IMPROVED SUGAR MARROW. IIuch better than the old White Marrowfat. Pods larger, well filled and of the true marrow flavor.

JUNO. Pods large and well filled peas of a dark green color

LONG ISLAND MAMMOTH. Very popular with market gardeners who want a large, handsome pod of a deep green color. 


\section{SEED POTATOES.}

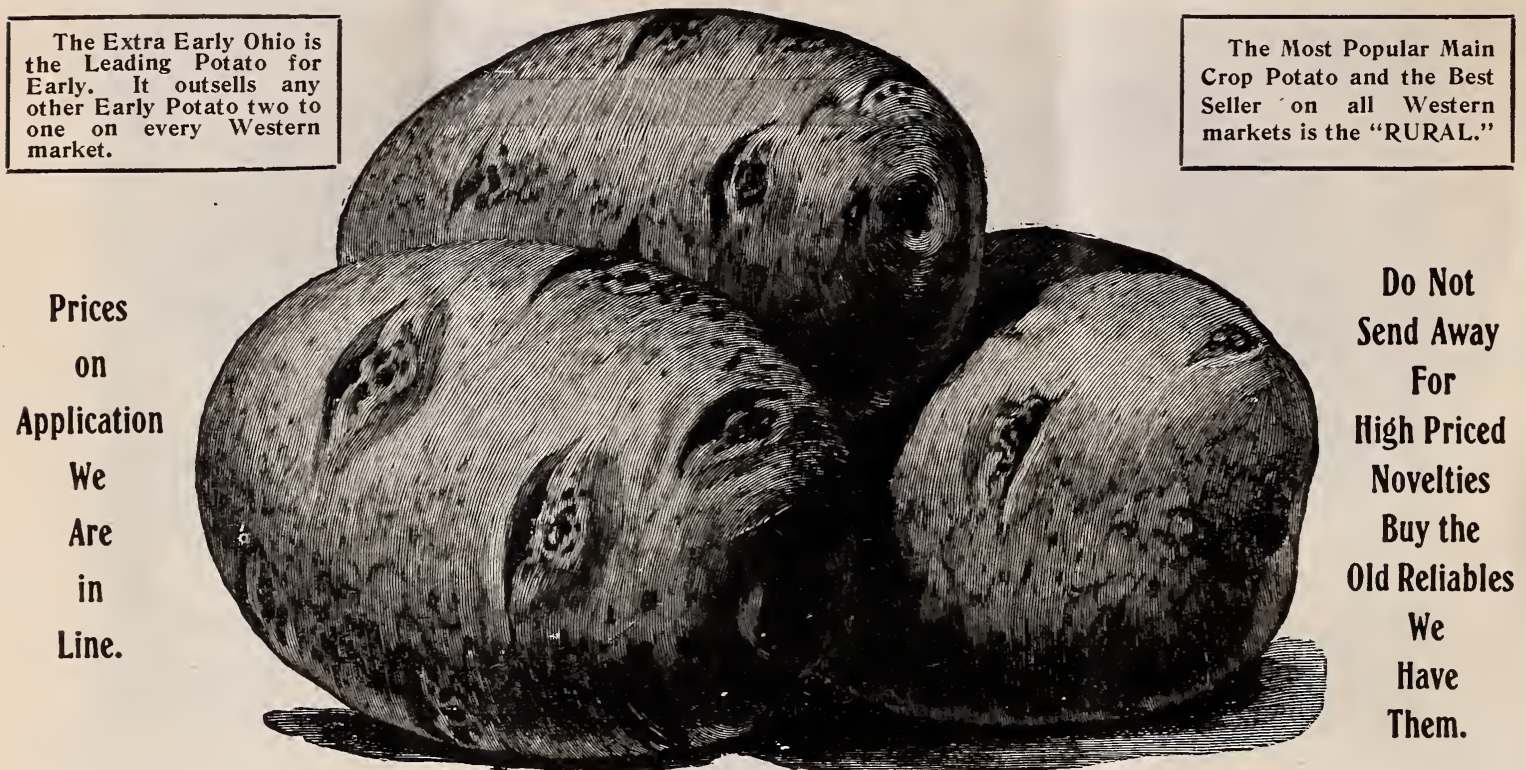

EARLY SIX WEEKS. Claimed by some to be earlier thân the old Ohio, and although we see very little difference, they are preferred by some of our gardeners.

EXTRA EARLY OH10. Absolutely the First Early Potato on the market. No other potato is so profitable for Potato on the market. No other potato is so profitable for A short, thick, round oblong potato. In color it is dull red. The flesh is solid, of extra good quality and flavor; very mealy even when only partially grown. Our stock is very pure and select.

EXTRA EARLY PINGREE. A most desirable variety. The shape is neither too long nor too round, very smooth and regular in form. Eyes shallow and a white skin. Top medium in size, but strong and spreading. Tubers close together in a in size, but strongerous hill and very numerous. About a week

EARLY ROSE. This well-known variety is still very popu-
EAW lar. Pure seed is hard to get. Ours is as pure as any to be had.

\section{PUMPKINS.}

CONNECTICUT FIELD. The common yellow variety usually grown for feeding stock. Good for canning and for pies. 0z., 5c.

LARGE CHEESE. A very hardy and productive variety, the best for cooking purposes. Oz., 5c.

CASHAW. A farorite sort, closely resembling the Crookneck Winter Squash. 0z., 5c.

LARGE TOURS, OR MAMMOTH. This rariety grows to an immense size, often weighing over 100 pounds. Pkt., 5c.; oz., 10c.

NEW PIE, "CALHOUN." It is medium in size, extradordinarily heavy quality. The outside is a cream color, while the flesh, which is very heick and fine grained, is a salmon vellow and of superior quality. It is undoubtedly one of the best for pies. Pkt., 5c.; oz., 10c.

GOLDEN OBLONG. A very fine, new and productive variety, growing oblong to a length of sixteen to eighteen inches, and seven to eight inches in diameter. Flesh rich yellow, very sweet, dry and excellent for pies. A good keeper. 0z., 5c.

QUAKER PIE. It is oval in shape, and tapers toward each end; of a creamy color, both inside and out. Being fine grained and rich flavored, it makes a superior quality of pies. Pkt., 5c.; oz., 10c.

WINTER OUEEN. This is an improvement of the old well liked sugar pumpkin, and is admitted by all who lrave grown it to be the very best pie pumpkin on the market. Its size is uniformly about nine to ten inches in diameter. In color, a beautiful deep orange yellow, with a very inches intineter. close netting, almost as russeted as a pota. $5 \mathrm{ct}$ is a good $10 \mathrm{c}$

and unequaled as a cooking variety. Prinest varieties ever introduced. It is a good keeper, of large size, very prolific, smooth and even fleshed, being free from that coarse stringiness which many varieties have. The Jonathan is excellent for pies. Pkt., 5c.; oz., 10c.

MAMMOTH POTIRON. The flesh and skin are of a bright golden yellow color. Flesh, fine grained, and of excellent quality. Notwithstanding its enormous size, it is one of the very best pie pumpkins ever grown, and a splendid keeper. This enormous variety has been grown to grown, and a splends. Pkt., 5c.; oz., 15 c.

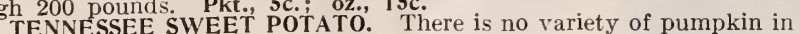
cultivation that has given as great satisfaction as this throughout the length and breadth of this country. Our sales of it have nearly doubled those of other sorts, and we have never received a single complaint of its growth or quality. Pkt., 5c.; oz., 10c.

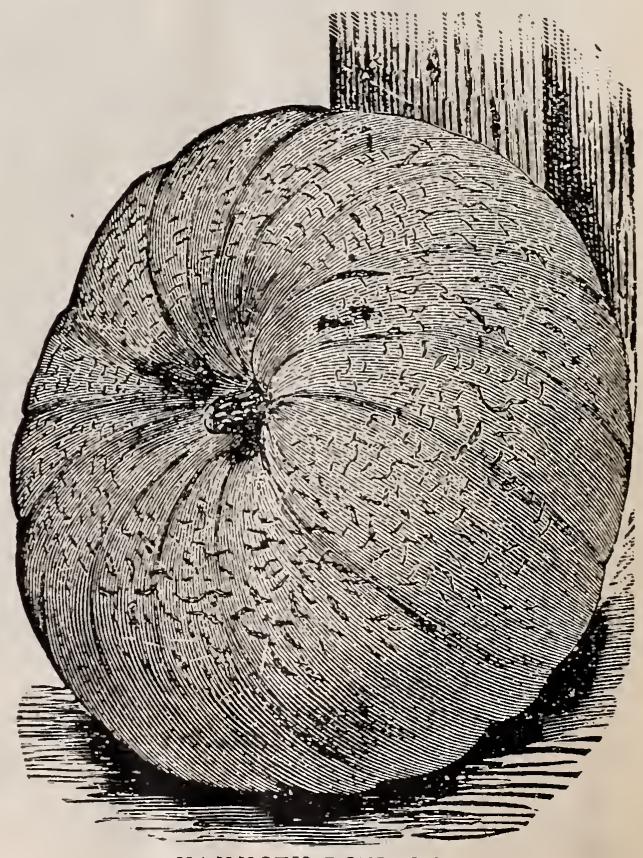

MAMMOTH POTIRON. 


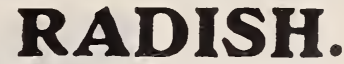

EARLY SCARLET TURNIP, WHITE TIPPED. One of the handsomest of the turnip radishes and a great favorite in many large markets, for early planting outdoors. It is but little later than the White Tipped Forcing, and will give entire satisfaction where extreme earliness is not the primary object. Roots slightly flattened on the under side; color, very deep scarlet with a white tip; flesh yhite and of the best quality.

XON PLUS ULTRA. This is one of the finest forcing radishes introduced, an 1 has already taken a leading place with our market gardeners. It will mature in eighteen to twenty days, and, owing to the extremely small tops, can be sown very tyickly. The roots are round, with a deep scarlet colored skin, the flesh white very crisp and tender.

OLIVE SHAPED BRIGHT RED LEAFLESS FORCING. The extra early forcing radishes lately introduced are remarkable for the small size of their leaves. They develop their roots in so short a time that the latter are practically in advance of the leaves.

EARLY SCARLET TURNIP. The standard early turnip radish. Fine flavofed and mild.

WHITE TIPPED SCARLET TURNIP.
EARLY CARMINE. An extra early variety of turnip-shaped radish. It is very mild and 至

othe radishes look dull and dry. This is a very bright colored scarlet turnip radish, very early and short leaf, well adapted to forcing under glass. Matures in fourteen to

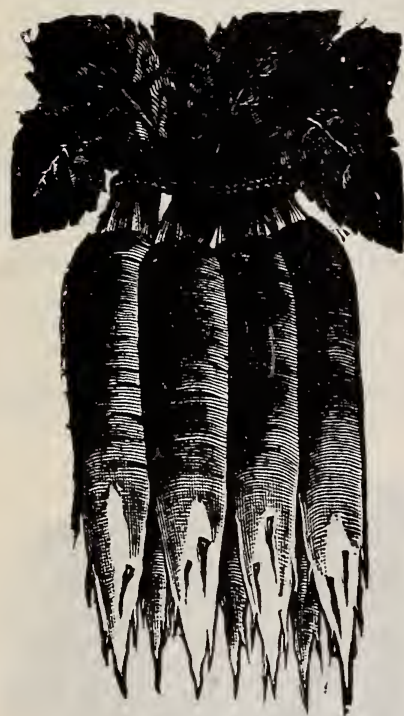

WHITE SUMMER TURNIP. A very large turnip-shaped variety; white, very crisp and

YELLOW SUMMER TURNIP. Like the above, except in color.

GRAY SUMMER TURNIP. Popular for midsummer planting.

LONG BRIGHTEST SCARLET, WHITE TIPPED. This is the brightest and handsomest colored scarlet radish known, and a decided improvement in earliness and color over other varieties of this class. It makes roots fit for use in about twenty-five days from time of planting, and they continue in good condition until they are full grown, when they are as large as the Wood's Early Frame. It has a small top and does not run to neck.

CRENCH BREAKFAST. Olive-shaped, scarlet, with white tip; crisp and tender. Vary early. A general favorite.

LONG WHITE VIENNA, OR LADY FINGER. A very excellent white variety with long, very smooth white roots, which are crisp and tender. It comes into use shortly after Wood's Frame, and is one of the most desirable of the white summer sorts.

/CHARTIER. Decidedly distinct in appearance from any radish in cultivation. Its form is well shown by our engraving, the color at the top being crimson, running into pink about the middle, and from thence downward it is a pure waxy white. It will at tain a very large size before it becomes unfit for the table.

U6NG SCARLET, SHORT TOP IMPROVED. This bright scarlet, small topped sort is about six inches long, grows half out of the ground, is uniformly straight, smooth, brittle and crisp, and is a standard and excellent sort for private gardens or market use.

WOOD'S EARLY FRAME. This is not only a good variety for forcing, being shorter and thicker than the old Long Scarlet Short Top, but is one of the very best sorts for first crop out of doors. It continues brittle and tender until July. The roots are very uniform in shape, smooth and vers bright red in color. The flesh is white and crisp.

WHITE, OLIVE. Like Scarlet Olive Shaped, except that the roots are clear white and a it tle longer.

WHITE STRASBURG, OR SUMMER HOSPITAL. Large, showy, half long, white sort. CHARTIER. Givs with great rapidity, sometimes producing a crop in six weeks.

Giant stuttaART. A summer variety. Grows to an immense size. White flesh, very crisp and tender. Of good flavor apd $x$ good keeper. EARLY SCARLET GLOBE. A desirable sort for hotbed forcing and outdoors; very attractive radishes, on account of its bright scarlet color and handsome shape. Is ready in twenty-eight days.

\section{WINTER RADISHES.}

Sow about the same time as winter turnips, on light, rich soil, in drills eighteen inches apart; give frequent cultivation, and thin two to six inches apart, according to size of the variety. For winter use pull before severe frost, and store in damp sand in cellar.

USARLET CHINA. Roots cylindrical, or largest at the bottorn tapering abruptlyto a small tap. Skin very smooth and of a brisht rose color; flesh firm, crisp, tender and quite pungent

HALF LONG BLACK SPANISH. An American sort of the same general character as the Long Black Spanish, but by many considered superior to either the Round or the Long Black Spanish. It is intermediate in shape between the two and seems to combine the good qualities of both.

LONG BLACK SPANISH. One of the latest, as well as LONG BLACK SPANISH. One of the latest, as well as
hardiest of the radishes. An excellent sort for winter use.

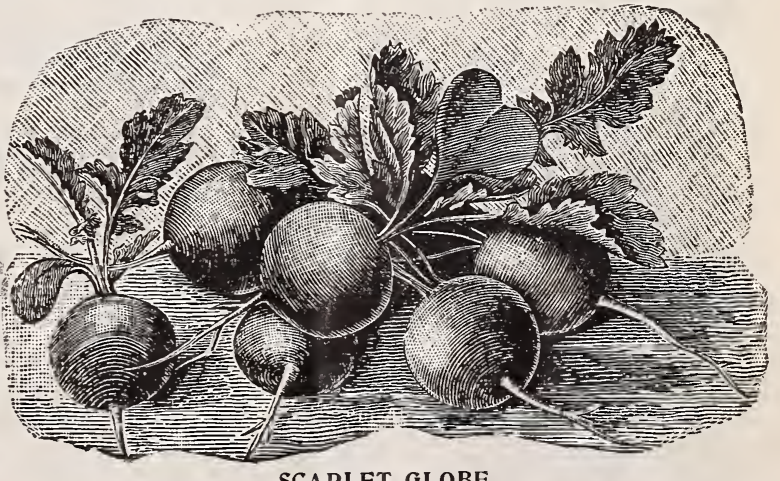

Early Scarlet Turnip, White $\quad 0 z, \quad \mathrm{t} / 4 \mathrm{lb}$ Tip ...............\$0 05 \$0 15

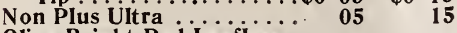
Olive Bright Red Leafless Forcing Earley Scarlet Turnip...... Early Carmine.

Deep Scarlet Turnip.........

White Summer Turnip.....

05
05
05

05

$05-15$
RADISH SELD PR. $1 / 4 \mathrm{lb}$.

Yellow Summer Turnip ...\$0 05 \$0 Gray Summer Turnip...

Long Brightest Scarlet,

White Tipped.

French Breakfast

Long White Vienna

Chartier.

Long Scarlet, short Top...
RADISH SEED PRICES.

SCARLET GLOBE.

Wood's Early Frame ..... 05

5
5
5
5
15
15

White Olive.

White Strasburg.

Giant Stuttgart

Early Scarlet Globe

Scarlet China.

Half Long Black Spanish

Long Black Spanish

5 California Mammoth White 


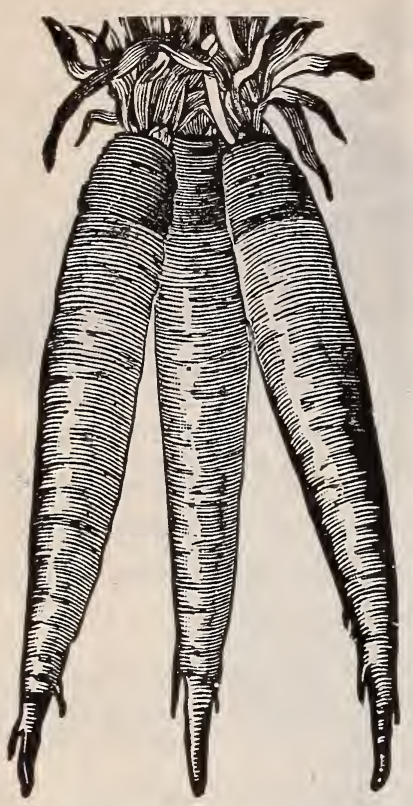

\section{RHUBARB.}

\section{(PIE PLANT.)}

Rhubarb, familiarly known as Pie Plant, or Wine Plant, is cultivated in gardens for its leaf stalks, which are used for pies and tarts. Immense quantities are now annually sold in all the large markets. No private garden should be without it.

CULTURE. Rhubarb surceeds best in deep, somewhat retentive soil. The richer its condition and the deeper it is stirred the better. Sow in drills an inch deep, and thin out the plants to six inches apart. In the fall transplant the young plants into very highly manured and deeply stirred soil, setting them four to six feet apart each way, and give a dressing of coarse manure every spring. The stalks should not be plucked until the second year, and the plant never allowed to exhaust itself by running to seed. Our seed is saved from selected plants of the Linnæus, Victoria, Giant and other improved sorts, but like the seeds of fruit plants of the Linnæus, Victoria, Giant and other improved sorts, but like the
trees, rhubarb seed cannot be relied upon to reproduce the same varieties.

RHUBARB SEED. Pkt., 5c.; oz., 15c.

RHUBARB ROOTS. By express, not prepaid, 20c each, $\$ 1.50$ per dozen. PRICES ON LARGE LOTS OF RHUBARB ROOTS ON APPLICATION.

\section{SALSIFY.}

\section{(VEGETABLE OYSTER.)}

The long, white tapering root of salsify resembles a small parsnip, and when cooked is a good substitute for oysters, having a very similar flavor.

Culture. It succeeds best in a light well-enriched soil, which should be stirred to a good depth. Coarse and fresh manure should be ayoided, as it will surely cause the roots to grow uneven and ill-shaped. Sow early and quite deep, giving the general culture recommended for parsnip. The roots are perfectly hardy, and may remain out all winter, but should be dug early in spring, as they deteriorate rapidly, after growth commences. Store a uantity for winter use in a pit or in a cellar in damp earth or sand.

LARGE WHITE. The common variety, roots medium sized, smooth; flesh white. Pkt., 5c.; oz., $10 \mathrm{c}$.

MAMMOTH SANDWICH ISLAND. This is in every way superior to the Large White, being larger, stronger growing and less liable to branch. Invaluable to market gardeners. Pkt., 5c.; oz., 10c.

\section{SPINACH.}

Spinach is very hardy, extremely wholesome and palatable and makes a delicious dish of greens, retaining its bright green color after cooking.

Culture. Should be planted in very rich ground, the richer the better. Sow in drills one foot apart and begin thinning out the plants when the leaves are an inch wide. All should be cut before hot weather or they will be tough and stringy. For early spring use, sow early in autumn and protect the plants with a slight covering of leaves or straw.

VICTORIA. An excellent scrt, which forms a very large, exceedingly thick, dark green leaf, somewhat curled in the center. It becomes fit for use nearly as early as any, remaining so much longer than most kinds, and cannot ail to please, whether grown for the market or in the private gardeh. Oz., 5 c.

SAVOY LEAVED. The earliest variety and one of the best to plant in autumn for early spring use. Plant of upright growth, with narrow, pointed leaves, which are curled like those of the Savoy cabbage. It groys quickly to a suitable size for use, but soon runs to seed. Oz., 5c.

ROUND SUMMER BROAD LEAVED. This variety is generally preferr in the north for early spring sowing, and is the favorite with our preferred in the north for early spling sowing, and is the favorite with our market gardeners. The leaves are large, thick and fleshy. Though not quite as

VIMPROVED THICH LEAVED. A variety which grows very rapidly, forming a cluster of large, very thick, slightly wrinkled leaves of fine color and quality when cooked. Especially recommended for market gardeners. 0 z., 5c.

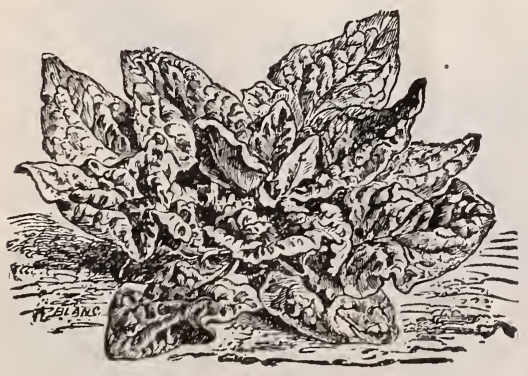

SAVOY LEAVED SPINACH.

LONG STANDING. An improved, round seeded strain of excellent merit, having all the good qualities of other sorts and continuing in condition for use much longer. The leaves are smooth and very dark, rich green. Very popular with market gardeners./ Oz., 5c.

PRICKLY WINTER. A very hardy variety and will withstand the severest veather with only a slight protection of leaves or straw. The seed is prickly, leaves triangular, oblong or arrow shaped. It is used for fall sowing, which in this latitude is about the first of September. Oz., 5 c.

\section{SUNFLOWER.}

Everyone who keeps poultry should use sunflower seed liberally for feeding, as there is nothing more wholesome and nutritious, or which keeps hens in better con-
dition for laying. Some species are largely planted in the flower garden for ornament. (See Flower Seeds.)

LARGE RUSSIAN. This variety has large heads, borne at top of a single unbranched stem, and having much more and larger seed than the common sort. Sow the seed as soon as the ground is fit for corn, in rows five feet apart, and ten inches apart in the row. Cultivate same as corn. When the seed as soon as the ground is fit for corn, in rows loosely in a rail pen having a solid floor or in a corn crib. After curing sufficiently, the seed is ripe and hard cut off the heads and pile loosely in a rail pen having a solid foor or in a corn crib. After curing sufficiently, so that they will thresh easily, flail out or run through a threshing machine, and clean with an ordinary fanning

will yield nine hundred to twelve hices change with market.

\section{SORREL.}

Those who think of sorrel as the starved looking weerl of barren lands have little idea of the possible value of the plant. The improved varieties, when well grown and cooked like spinach, make a healthful and very palatable dish. Sow in drills early in spring, and thin the seedlings to six or eight inches apart in the row. One may commence cutting in about two months, and the plants will continue in full bearing from three to four years.

LARGE LEAVED FRENCH. The best garden variety, having large pale green leaves of fine quality. Pkt., 5c.; oz., 15c. 


\section{SQUASH.}

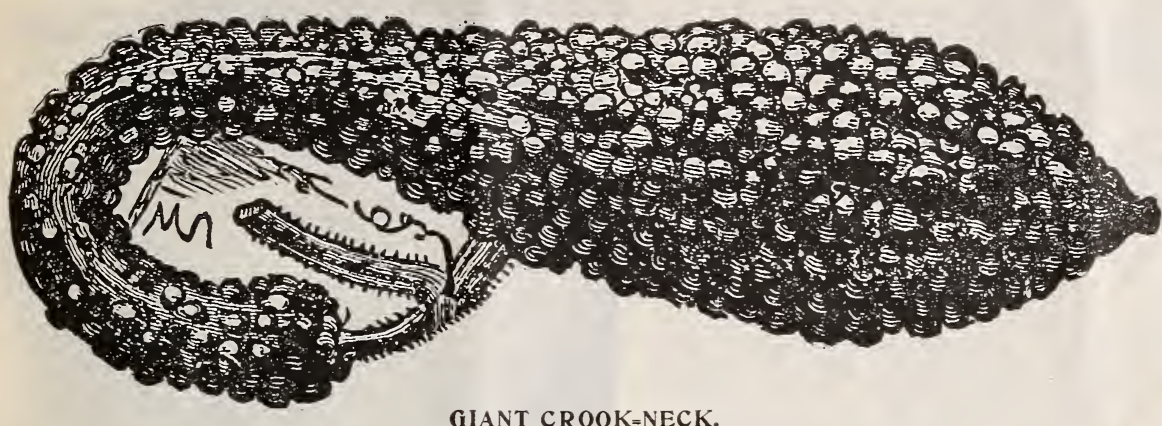

GIANT CROOK=NECK. This strain is a great improvement on the old variety of Crook-neck. It is larger and better in every way.

STRAIGHT $=$ NECK SUM= M E R S Q U A S H. Market gardeners who ship early squash to distant markets know the difficulty of packing the crook-necked variety in boxes to good advantage. In our Straight-neck the bad feature of the crook has been vercome, and by continued selection the size has been increased more uniformly in shape improved quality

G $O$ L D E N CUSTARD

GIANT CROOK=NECK. BUSH. Exceeds in size any

dark, rick golden yellow. Quality excellent. It grows in bush form, wonderfully productive

DELICATA. Early and very prolific; of oblong shape. Ground color, orange yellow, splashed and striped with very dark green. Although of small size, the squashes are very solid and heavy, while the quality is rich and dry.

EARLY WHITE BUSH SCALLOP. Similar in form to the preceding, but with a cream white skin, and more tender and delicate flesh.

MAMMOTH WHITE BUSH. This has been obtained by years of careful selection. Although we have sold this squash for a number of years, we again call special attention to it.

MAMMOTH CHILI. The largest of all squashes, growing to an immense size, often weighing over two hundred pounds, while its rich, fine-flavored flesh insures its value for all purposes.

ORANGE MARROW. A variety developed by selection from the Boston Marrow and not so large but much earlier, and the earliest of the winter varieties. Fruit deep orange color netted with cream;

Boston Marrow; flesh thick, deep yellow, of fine qual

ESSEX HYBRID. This is not only one of the richest flavored, finest grain and sweetest of all squashes, but it is also one of the very best keepers that we know of. Short cylindrical shape, having on the blossom end a small cap shaped enlargement. The flesh is dry, sweet and thick, and of a bright orange color.

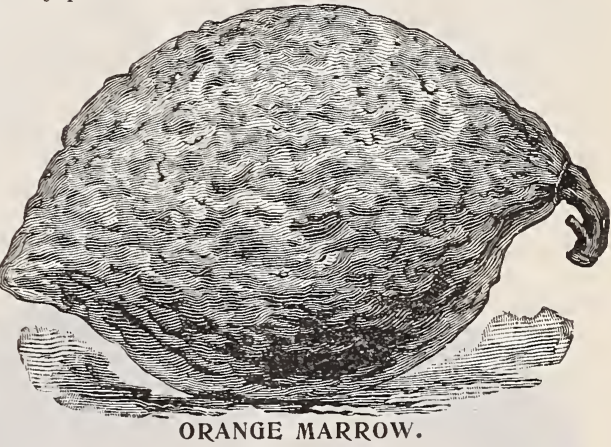

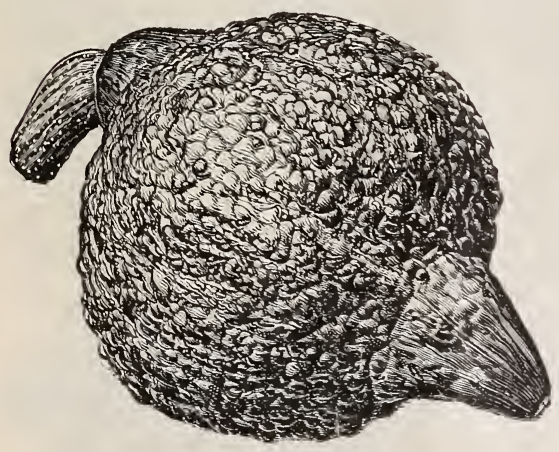

WARTY HUBBARD.

BOSTON MARROW. Second early, coming in about ten days after the Bush and Crook-neck sorts. Skin yellowish, very thin; the flesh dry and fine grained, and of unsurpassed flavor.

HUBBARD. A general favorite and more largely grown as a late sort than any other; it is of large size, often weighing from nine to ten pounds. Color bluish green, occasionally marked with brownish orange or yellow. Flesh fine grained, dry, and of excellent flavor. It can be had in use from September to May.

WARTY HUBBARD. Also called Chicago Warted Hubbard. This strain of squash was introduced by $\mathrm{S}$. $\mathrm{F}$. Leonard in 1894. It originated with John Oly, an old-time Chicago market gardener, and for years previous to its general introduction to the trade was known at Chicago as Leonard's Warty Hubbard, which is its proper name. Ours is headquarters seed.

Best for Baking-Best for Pies-the Best Keeping Winter Squash is the Warty Hubbard.

For Pumpkin Pies use the Winter Queen see Page 18.

\section{SQUASH PRICE LIST.}

Giant Straight=neck. . . \$0 05

Golden Custard. .

Delicata.

Giant Crook

White Bush 05

Mammoth White Bush : 05 $\begin{array}{lll}1 / 4 & 1 b \\ \$ 0 & 15\end{array}$

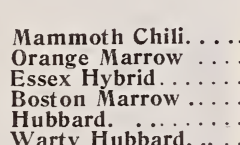

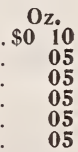

\section{TOBACCO.}

PENNSYLVANIA SEED LEAF. This is the variety mostly grown for cigars, and is of fine quality and excellent flavor. Pkt. 5c.; oz. 20c.

PERSIAN ROSE. A fine brand for cigars. Sells well. Pkt. 5c.; oz. 20c.

YELLOW PRYOR. A fine yellow sort, and succeeds well where others fail.

Pkt. 5c.; oz. $20 \mathrm{c}$.

BLUE PRYOR. This is the genuine article and a good sort. Pkt. 5c.; oz., 20c. GENERAL GRANT. Very early. and a good yielder. Pkt., 5c.; oz., 20c. CONNECTICUT SEED LEAF. The best sort for cigar wrappers. Try it. Pkt., 5c.; oz., 20c.
z., $20 \mathrm{c}$.

HAVANA. This is the genuine article, and is first-class. Pkt.
OHIO. White leaved. A large yielder. Pkt., 5c.; oz: 20c.

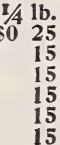

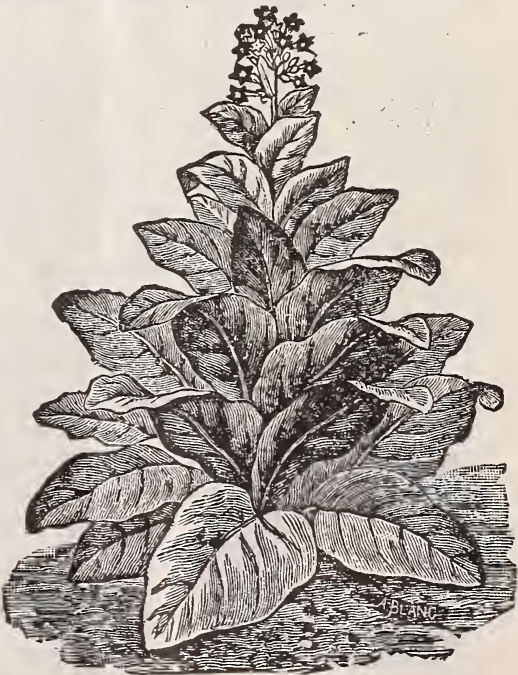

CONNECTICUT SEED LEAF TOBACCO. 


\section{TOMATO.}

This is a very important vegetable for a market gardener. Each Market demands its own special favorite, and market gardeners must look out and get the proper kind, which the market they supply needs. Unless you are sure that a new variety is all right, stick to the old one.

BEAUTY. A decided favorite for either home market or shipping purposes, being early, hardy, a strong grower, productive, large size, always smooth, perfect in shape, and excellent in quality. The color is a very glossy crimson, with a tinge of purple. It grows in clusters of four ining its large size late in the season. It ripens with Acme and Perfection, and is entirely free from ribbed and elongated fruit.

ESSEX HYBRI

This variety we consider the best market sort. It is like Acme in color and general appearance, but runs larger, smoother and, as a rule, better. Pkt., 5c.; oz., 15c.

MAGNUS. A new variety. It is very distinct, having the color of Livingston's Beauty and Acme, but thicker, heavier and more solid than either. The form is uniformly perfect, large and attractive, very deep from blossom to stem, and almost globe shaped. Fruit in clusters, ripening evenly and maturing quickly enough for early

MIKADO, or TURNER'S HYBRID. One of the latest of the good market varieties. The vines are very distinct. Have a potato leaf appearance. In color, this sort is like the Acme, fine, large, smooth fruit. Pkt., 5c.; oz., 15c.

PONDEROSA. This variety, when conditions are farorable, grows to an immense size and makes the heaviest fruit of any in the list. Our stock is from the original strain. None better. Pkt., 5c.; oz., 15 c.

BUCKEYE STATE. A mammoth growing tomato of smooth form and extra quality. The largest fruited variety yet introduced. Pkt., 5c.; oz., 15c.

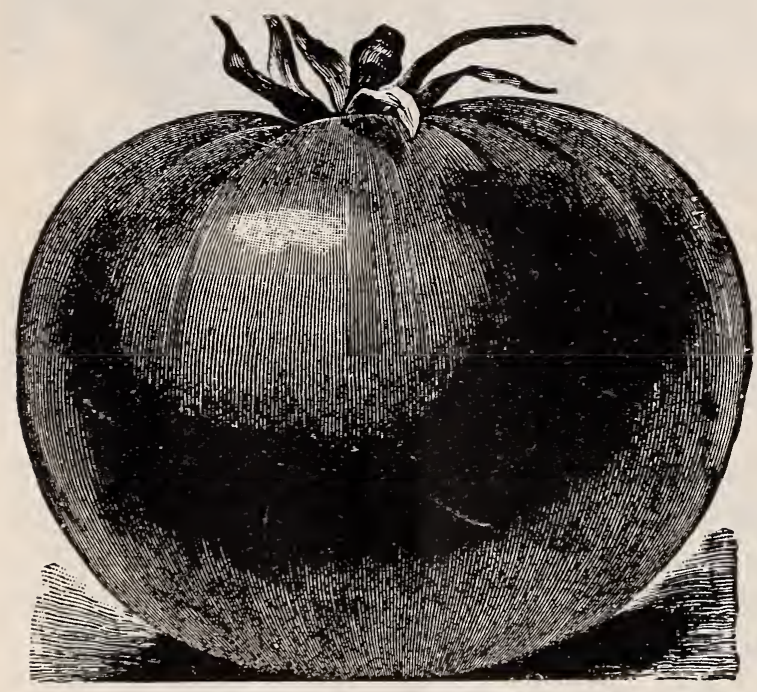

SPARKS' EARLIANA. Said to be the earliest large tomato in the world. This tomato is not only remarkable for its earliness, but for its very large size, handsome shape and bright, red color. Its solidity and fine quality are quite equal to the best medium and late sorts., From less than 4,000 hills the originator realized from his first pickings $\$ 725.00$ clear of freight and commission, being in the market fully a week before all others. Pkt. 5c.; oz., 20c.

THE NEW IMPERIAL. Without doubt, this is the best main crop tomato now in cultivation. It is large, solid and smooth; has the right color for the Chicago market, and makes the evenest, handsomest show in the tomato box of any we have We think it better than Acme Essex Hybrid or Beauty. and that is as much as we need say of any tomato. Pkt., 5c.; oz., 15c.

LIVINGSTON'S FAVORITE. A well known red rariety, smooth and solid. Pkt., 5c.; oz., 15c.

OPTIMUS. One of the best table tomatoes. Vine medium sized, vigorous and strong. While not classed as a first early. $i t$ is reported by growers to ripen fully as early as many of the earliest, making an excellent forcing variety. The fruit is medium sized, oval, very smooth, and of a very bright crimsonscarlet color. Pkt., 5c.; oz., 15c.

PERFECTION. A splendid red variety, hardy, productive, and good bearer. Pkt., 5c.; oz., $15 \mathrm{c}$.

ATLANTIC PRIZE. A very early variety, fairly smooth; good for first crop. Pkt., 5c.; oz., 15c.

TROPHY. A good main crop sort. Color, red, fruit large. Pkt., 5c.; oz., 15c.

THE HONOR BRIGHT. This is a remarkable red variety. The color of the fruit, when fully ripe, is a rich, bright red; but, before reaching this stage, it undergoes several interesting changes. First it is a light green; then an attractive, waxy white; then lemon, changing to red. Pkt., 5c.; oz., 15c.

DWARF CHAMPION. This is a purple fruited variety, which forms very strong plants about two feet high. The branches are short, making a bushy plant that stands quite erect without stakes. This sort is often sold as Tree Tomato. Fruit smooth, medium sized, color purplish pink, fairly solid, but has no hard core, and is of good flavor. About as early as any purple fruited tomato, and is quite popular in som

NEW STONE. A fine new, red variety, rery solid and smooth; a splendid main crop sort. Pkt., 5c.; oz., 15c.

MATCHLESS. A good canning and all purpose tomato; splendid for kitchen. Pkt., 5c.; oz., 15c.

ROYAL RED. A new sort, of considerable merit. Vines vigorous; fruit smooth. Very productive. Pkt., 5c.; oz., 15c.

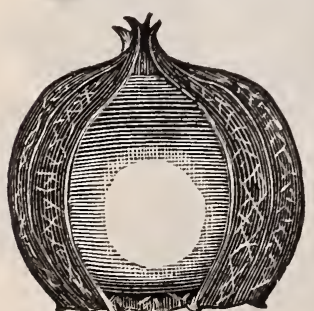

HUSK TOMATO.

YELLOW PLUM. A small, yellow variety, of handsome appearance and fair quality. Pkt.,

HUSK, or GROUND CHERRY. This is a small sized fruit grown within a husk. It is valuable for preserving, for making into pies, 5 c.; oz. 20c.

ACME. One of the best standard sorts. Of a fine crimson purplish color. Shape is smooth, size large and uniform. For the market or home garden no sort is better. Pkt., 5c.; oz., 15c.

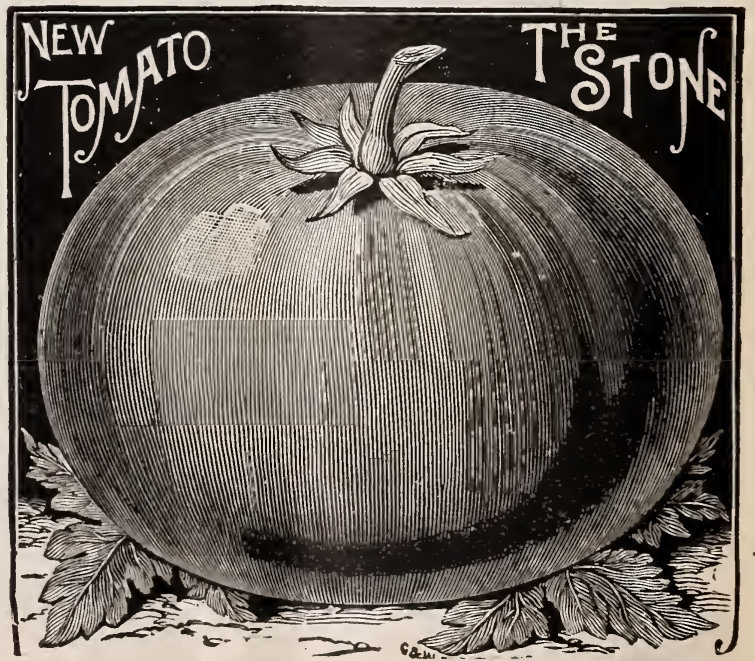




\section{Hsc TURNIP.}

EXTRA EARLY WHITE MILAN TURNIP. The Purple Top Milan is one of our most popular turnips for spring sowing, but in this new sort we have a splendid extra early turnip in which the extreme earliness, small top and tap root of the Purple Top Milan is united with clear white skin and flesh. It will undoubtedly find a welcome in our markets, as, in addition to the heavy crop assured by its adaptability for close planting, it will be found to be fit for

- POMERANEAN WHITE GLOBE. This is one of the most productive kinds, and in good, rich soil roots will frequently grow to twelve pounds in weight. It is of perfect globe shape; skin white and smooth; leaves large and dark green.

PURPLE TOP WHITE GLOBE. An early variety. Globe shaped; heavy

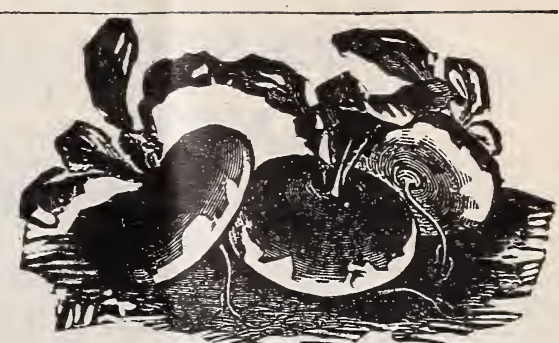

EXTRA EARLY PURPLE TOP MILAN.

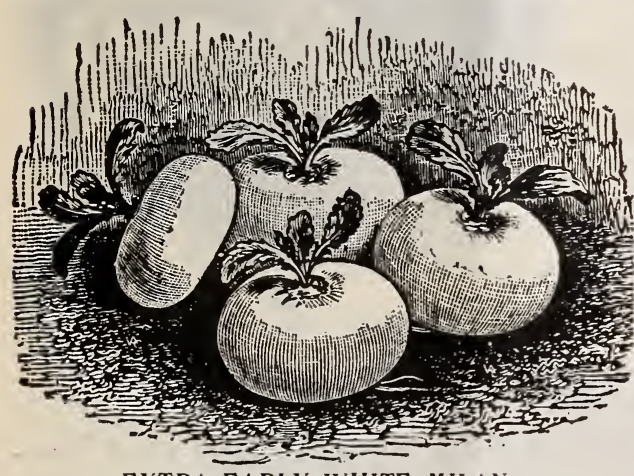

EXTRA EARLY WHITE MILAN. looking bulb. And is rapidly taking the lead of all other varieties of early turnips for market garden purposes.

$\checkmark$ EXTRA EARLY PURPLE TOP MILAN. The earliest in cultivation, two weeks earlier than Purple Top Strap Leaf. The bulb is flat, of medium size, quite smooth, with a purple top. Flesh, white, hard and of finest quality. It is an extra good keeper.

LARGE WHITE NORFOLK. The standard variety for field culture or feeding stock. Very large size.

LOW HORN. This variety is pure white, except a little shade of green at the top, and is carrot-like in form, growing nearly half out of the ground, and slightly crooked. It is delicate and well flavored, of very rapid growth, and has obtained considerable favor as a market sort for fall axd early winter use.

EARLY SNOWBALL. A perfectly globe-shaped, white-skinnerl turnip It is exceedingly productive. The flesh is fine grained, firm and of very delicate flavor. It is one of the best keeping of the white-fleshed sorts. Very early and particularly adapted for family or market use. We recommend it to market gardeners because its earliness and fine appearance make it a very profitable variety of turnip.

$\checkmark$ EARLY WHITE FLAT DUTCH. An excellent garden variety. The fort foring sowing.

4 WHITE EGG. Belongs to the class of quick growing fall turnips, and for this purpose should be sown, in this latitude between August 10th and 25th. Its shape is nearly oval or egg, as its name would indicate.

HWEET GERMAN. This variety is very popular in many sections, notably so in the New England States. It partakes largely of the nature of the rutabaga and should be sown a month earlier than the flat turnips. The flesh is white, hard, firm and sweet; keeps nearly as well as the rutabaga. Highly recommended for winter and spring use.

1 SEVEN TOP. Cultivated extensively in the south for the tops, which are used for greens. It is very hardy and will grow all winter, but does not produce a good root, and is only recommended for the tops.

1. PURPLE TOP MUNICH. The earliest variety after the Red Top Milan. Color -white, with purplish white top.

1 PURPLE TOP STRAP LEAF. Rapid grower and mild flavor. The most Dopular variety for early use, either for the table or stock.

SCARLET KASHMYR. A most distinct novelty; of such peculiar color that it has a striking resemblance to a large radish. "Unwarned judges would, no doubt, pronounce it one of those radishes so persistently complained of as tasting like turnips." However, it is a turnip, and of most excellent flavor; of a deep rich crimson above, shading to a soft crimson rose below.

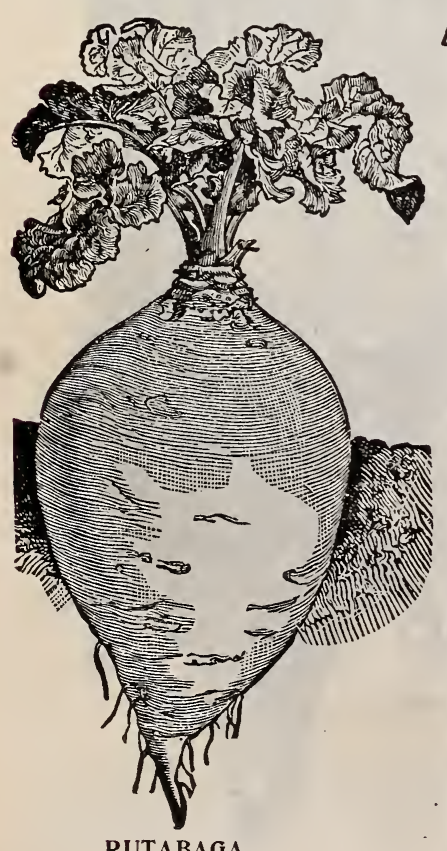

lyxdy and L O W ABERDEEN. Very

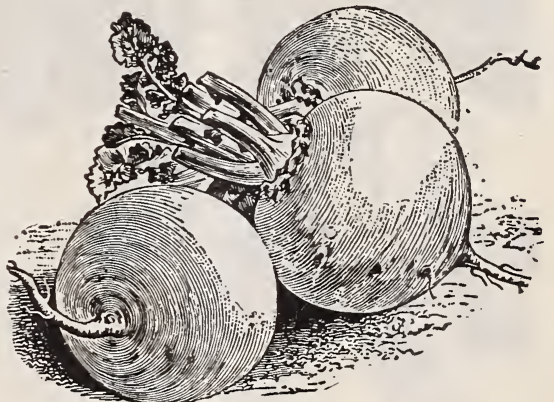

EARLY SNOWBALL. globe shaped. Color pale yellow, with purple top. Very firm in texture, and closely resembling the Rutabaga in good keeping qualities. Good either for table or stock.

2 LARGE AMBER GLOBE. One of the best varieties for a field crop for stock. Flesh yellow, fine grained and sweet; color of skin yellow, top green. Hardy, keeps well, a good cropper. Very popular in the South.

\section{PRICES.}

All Turnips and Rutabaga-oż., 5c.; $\frac{1}{1}$ lb., $15 \mathrm{c}$.

\section{RUTABAGA. SWEDISH TURNIP.}

IMPROVED A MERICAN. The best yellow fleshed, purple top variety grown for stock or table.

BUDLONG'S WHITE ROCK. Though sometimes called a turnip, this is more like a rutabaga. The root is large, both skin and flesh very white, and it is one of the best varieties we have for table use. An excellent keeper and a desirable sort for market gardeners.

WHITE RUTABAGA. This variety is now extensively cultivated, and preferred in many sections for its white flesh. It is very hardy and productive, keeps well until late in the spring, and is highly esteemed for its sweet, delicate flavor.

LAING'S IMPROVED. One of the earliest of the rutabagas. Forms a handsome b of good quality. Keep well; good for table use.

LONG WHITE FRENCH. A rery delicate flarored variety. An excellent keeper and fine foy table.

SKIRVING'S PURPLE TOP. A very heavy cropper. One of the best for field cluture.

RUTABAGA, 


\section{PANSY (Masterpiece.) \\ GIANT CURLED.}

OUR SPECIAL STRAINS OF POPULAR FLOWERS.

Our seed is true and pure from the originator. This strain comes nearer to Double Pansies than anything ever introduced under that name. In reality the number of petals is the same as that in other pansy flowers, but they are crimped and curled in such a fashion that the flowers appear double. The flowers are of enormous size, often three inches across, and the color variations and combinations are odd and striking. Pkt., 10c.

\section{SUPERB NASTURTIUMS.}

For ease of culture, duration of bloom, brilliancy of coloring and genera excellence, nothing excels Nasturtiuns. All they need is a moderately good soil in a well drained, sur y position, and from within a few weeks from the time they are sown until hard frost comes there is an endless profusion of their gorgeous blossoms.

The identical colors can be had in either the Tall, or Climbing, or Dwarf or Tom Thumb types. The former grows 5 to 6 feet high; and are unexcelled for growing on fences, trellis; or trailing over rocks and rough ground, etc.,
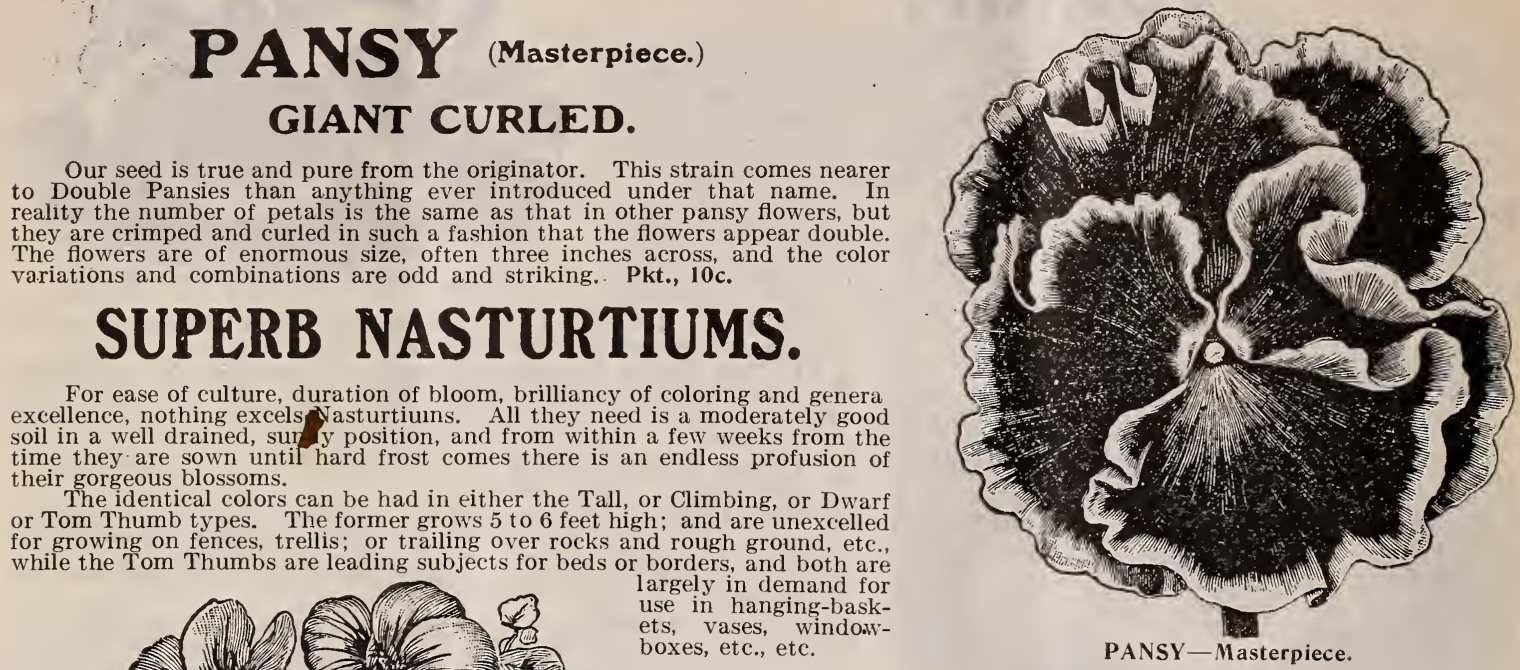

EITHER DWARF OR TALL VARIETIES.

In Ordering, State Whether You Want Dwarf or Tall.
DWARF OR TALL SPOTTED. Rich Orange-Yellow, spotted crimson.

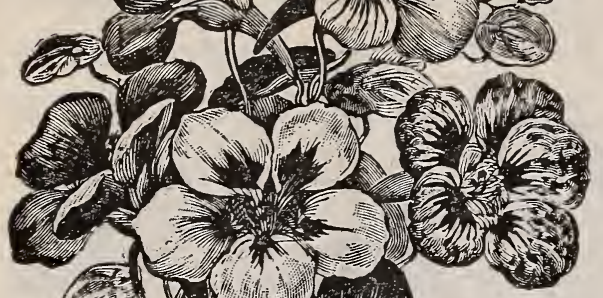
PRINCE HENRY. Creamy White, spotted and tipped with scarlet.

CoMELON. This variety bears different colored flowers on the same plant; the flower shown is one of the most frequently seen combinations.

CHOCOLATE, A unique color, odd.

DWARF OR TALL SPOTTED, ORA N G E. kure orange, without markings of any

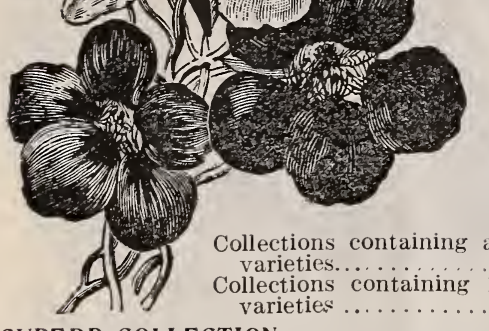

DWARF OR TALL SPOTTED. PEARL. Creamy white. KING THE O D ORE.

Deep crimson-maroon, with black shadings.

DWARF OR TAI.L SPOTTED. VESUVIUS. Salmony DWARF OR TALL SPOTTED. ROSE Arice: Any of the above 5c. per pkt., 10c. per oz.

SUPERB COLLECTION

OF NASTURTIUMS.

\section{"Incomparable" Collection of SWEET PEAS.}

This collection is made up of very choice sorts-varieties that have the endorsement of the leading American and European specialists-and it would be impossible to select another similar collection out of the vast number of sorts now in commerce that would combine, in the same degree, all the qualities which go to make up first-class varieties.

AMERICA. Bright, blood-red striped on a white ground. BLANCHE FERRY EXTRA EARLY. The popular pink and white. COCCINEA Rich brilliant cerise.

COUNTESS CADOGAN. The brightest blue

DOROTHY TENNANT. Deep mauve; a lovely shade.

DOROTHY TENNANT. Deep mauve; a lovely shade.

GORGEOUS. Bright Orange, wings rose-tinged orange.

LADY GRISEL HAMILTON. The finest pale lavender.

LADY MARY CURRIE. Bright Crimson orange.

LOTTIE ECKFORD. White shaded and erged
PRINCE OF WALES. The finest bright rose.

QUEEN VICTORIA. Primrose-Yellow.

SADIE BURPEE. Very large pure white.

SALOPIAN. Deep scarlet or carrlinal; the finest red.

STELLA MORSE. Primrose, tinged blush; effect a rich cream color.

LOVELY. Soft shell-pink. an exquisite shade.

MODESTY. The most delicate shade of all the pinks.

NAVY BLUE. Deep indigo-blue.

OTHELLO. Very dark maroon.

PRIMA DONNA. A magnificent pure pink.

PRINCE EDWARD OF YORK. Scarlet tinged crimson.

Prices: Any of the above, 5c. per pkt.; 10c. per oz.; 20c. per 1 Ib.; 50c. per lb.

Collection of a packet each of any 21 "incomparable" varieties, $60 \mathrm{c}$., or 1 oz. of each $\$ 1.00$, postpaid.

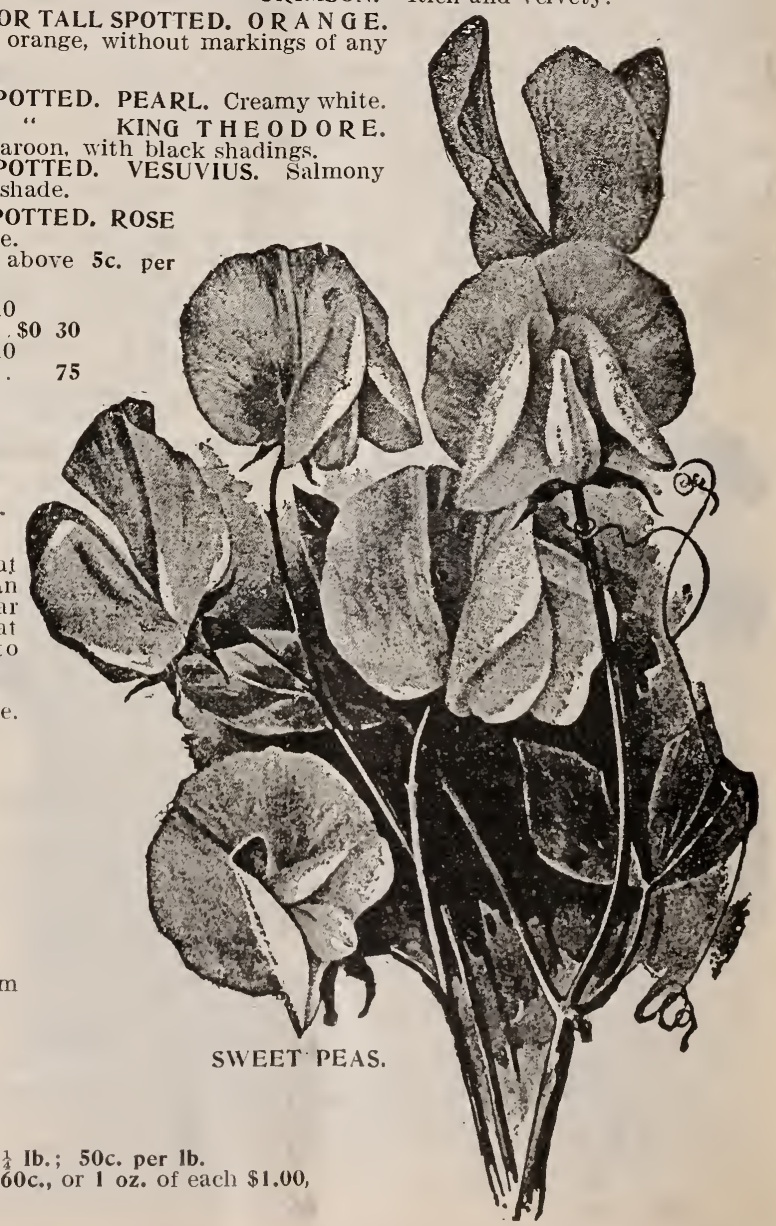




\section{Our Special Strains of Popular Flowers.}

\section{PETUNIAS.}

For outdoor decoration or house culture, few plants are equal to this class. They commence to bloom early, and continue to flower through the summer. Give them rich soil and a sunny place.

\section{SINGLE VARIETIES.}

Single Large Flowering, mixed, all colors. .

Pkt. 10c Fine Mixed, all colors.

\section{LARGE FLOWERING DOUBLE PETUNIAS.}

Grand, rich, velvety flowers of the largest size. All colors and shades, beautifully veined. Most of the flowers are fringed, and our seed will produce a far greater per cent of double flowers than any other strain. Pkt., 25c

It is well known that seed saved from the most carefully hybridized flowers produces but a small percentage of double flowers, the balance being singles of unusually fine quality. The weaker seedling should be carefully saved, as these invariably produce the finest double flowers.

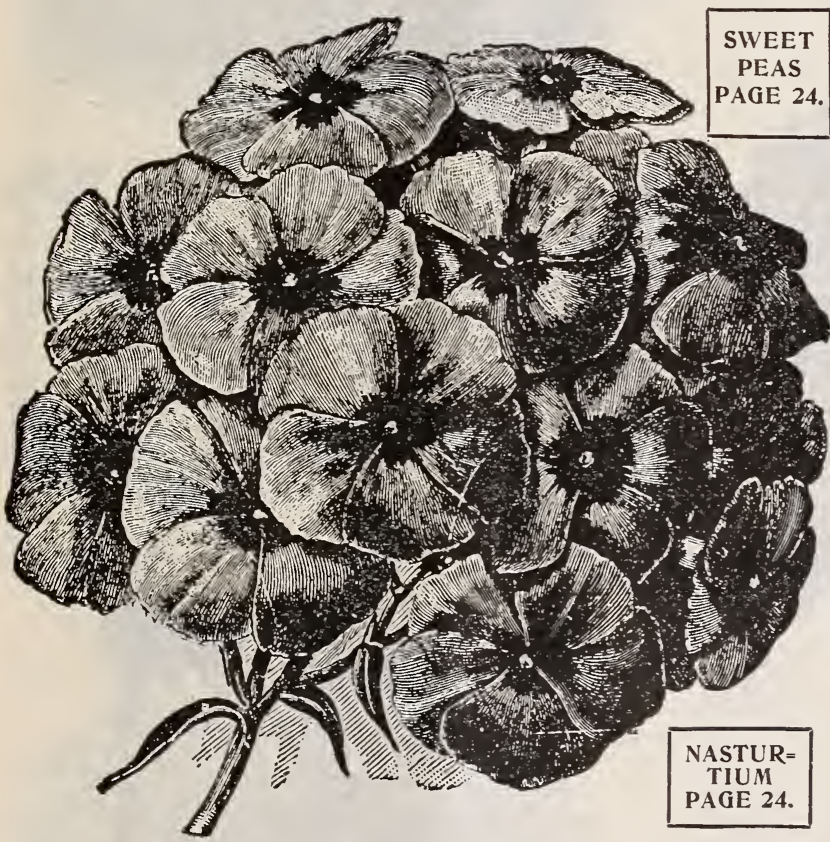

LARGE FLOWERING PHLOX.

\section{SUPERB ASTERS.}

Of the general beauty of these flowers it is unnecessary to speak the immense world-ide demand for them for any climate: flowers are fading away, enhances their value do, when most othe thewers are fading away, enhances their value. For the best results the ground for the cultivation of Asters cannot be too richly prepared, soil.

Standard Prize Mixture, Victoria

Pkt., $10 \mathrm{c}$

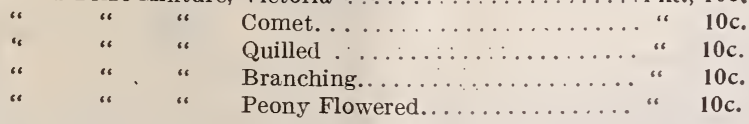

\section{CHRISTMAS TREE ASTER.}

This Aster has a pyramidal branching form of growth, giving it the shape of a miniature tree. A very early profuse bloomer, growing about fifteen inches high, but covering an area of from twenty inche to two feet in diameter. Perfect double flowers, all colors, mixed. Pkt., 10c.

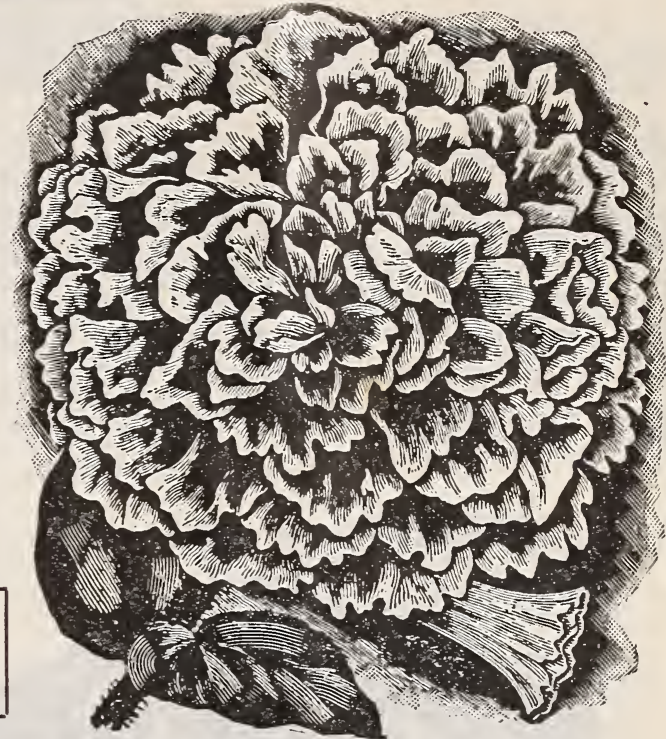

LARGE FLOWERING DOUBLE PETUNIA.

\section{PHLOX DRUMMONDI.}

Of all summer-flowering annuals the varieties of Phlox Drummondi are unquestionably one of the most brilliant and satisfactory. Seed may be sown in the open ground ny time after danger from frost is past, and in a few week the beds or borders are aglow with their brilliant coloring, For early flower

Phlox Drummondi, mixed colors....Per oz., 50c.; pkt., 5c.

\section{LARGE FLOWERING PHLOX.}

The largest flowering of the annual Phloxes. Nothing can compare with this indispensable summer flower for beds, massing, etc. Our strain is very select. Large perfect types of most beautiful colors, shades and marking. robust growers.

Large Flowering Phlox, mixed colors .........Pkt., 10c.

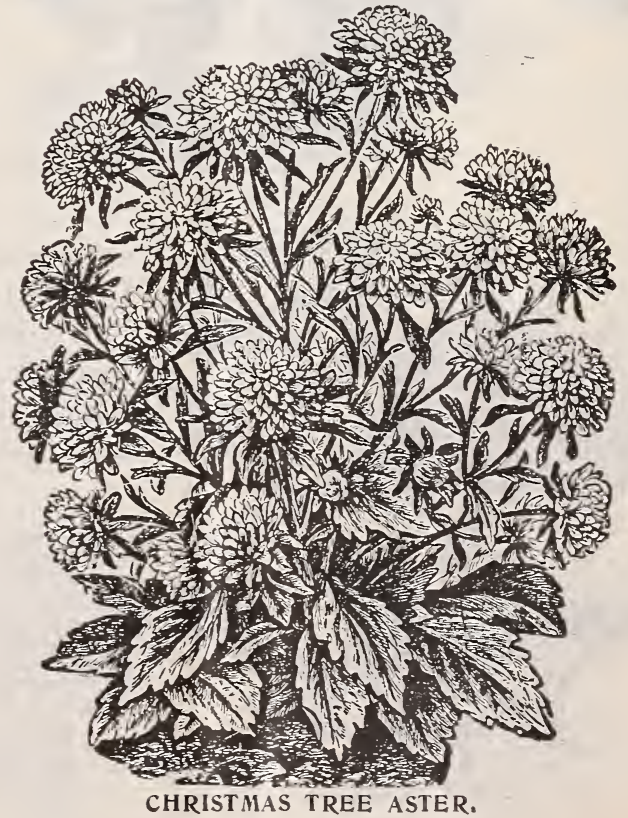




\section{CHOICE FLOWER SEEDS.}

\section{Standard Varieties.}

The following is a list of the leading flowers grown from seed. While they are not all annuals, they will bloom the first season, some of course, being planted somewhat earlier than others. We have listed only those strains that are reliable, and are sure to satisfy our customers. Our prices will be found as low as any reliable house for quality and quantity given. These varieties are especially_adapted for market gardeners. All flower seeds sent free by mail at catalogue prices.

Abronia, umbellata, mixed. . Acroclinum, album

Ageratum Mexicanum, light blue

Agrostemma, mixed

Alyssum, sweet maritimum. .

Little Gem, benthami, compactum, erectrum

Amaranthus, Tricolor, Joseph's Coat

Antirrhinum, majus, mixed

Tom Thumb, mixed, fine strain .

Auricula mixed.

Bachelor's Button, centaurea cyanus

$$
\text { Double mixed, }
$$

Balloon Vine, cardiospernum halicacabum.

Balsam, White Perfection ..

$$
\begin{aligned}
& \text { Camellia, mixed. } \\
& \text { red... } \\
& \text { striped. }
\end{aligned}
$$

Roseflowered, mixed

Brachycome Iberdifolia, Swan River Daisy, mixed..

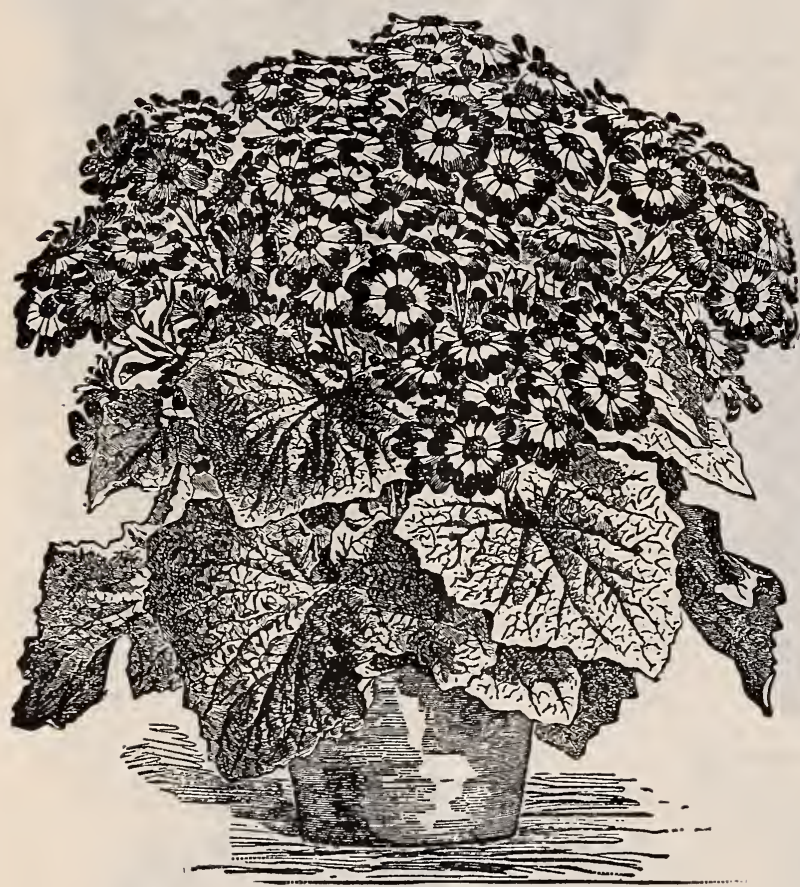

Per Pkt

05 moll

05
05
05

05

05

05

05

05

10
05
10
05

105

10

10

05

Calliopsis, fine, mixed.

white.

White Rocket.

Canna Indica, fine, mixed.

Crozy, mixed ...

Canterbury Belle, campanula media, single, mixed ... Double, mixed

Carnation, fine .

Margaret, finest, mixed.
Castor Beans.....................

Chrysanthemum Coronarium, double, mixed . Double, white.

Cineraria Hybridia, large flowering, mixed .

Cobea Scandens ..................

Cockscomb, mixed.

Cockscomb, mixed..................

Convolvulus Minor, Dwarf Morning Giory.

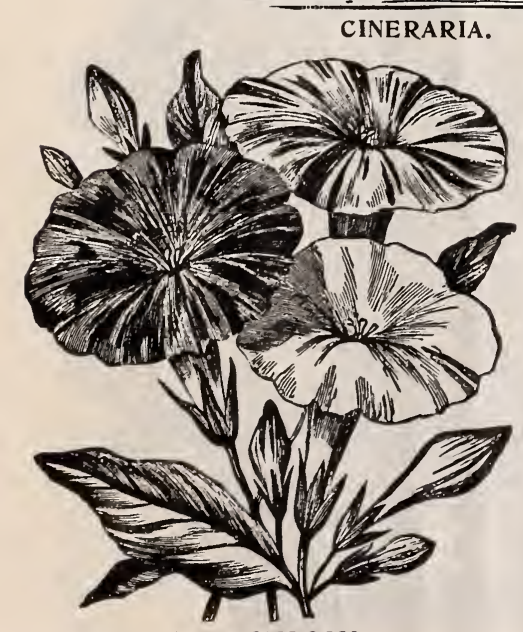

FOUR O'CLOCK.

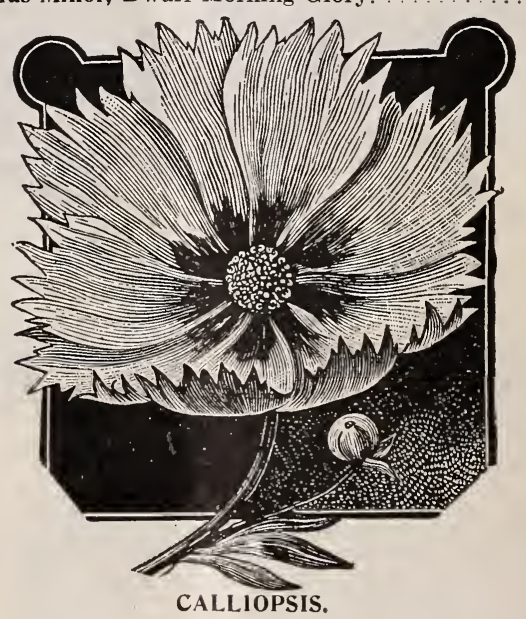

Cypress Vine, mixed.

Dahlia, finest, double, mixed Single, mixed

All the Varieties of

Flower Seeds we list are]

the kinds that should

be in every garden.

CALLIOPSIS.

Daisy, finest quality, double, mixed

Eschscholtzia Californica, finest, mixed colors.

Forget $=$ Me $=$ Not, myosotis alpestris, blue

Four 0'Clock, Marvel of Peru, mixed .

Globe A maranth, gomphrena globosa, mixerl.

Gourd, dish cloth

$$
\begin{aligned}
& \text { Japanese Nest Egg. } \\
& \text { Hercules Club..... } \\
& \text { Pear shaped. } \\
& \text { Sugar Trough ...... } \\
& \text { Mixed ........... }
\end{aligned}
$$

Per Pkt. \$0 05

05

05

05

05 


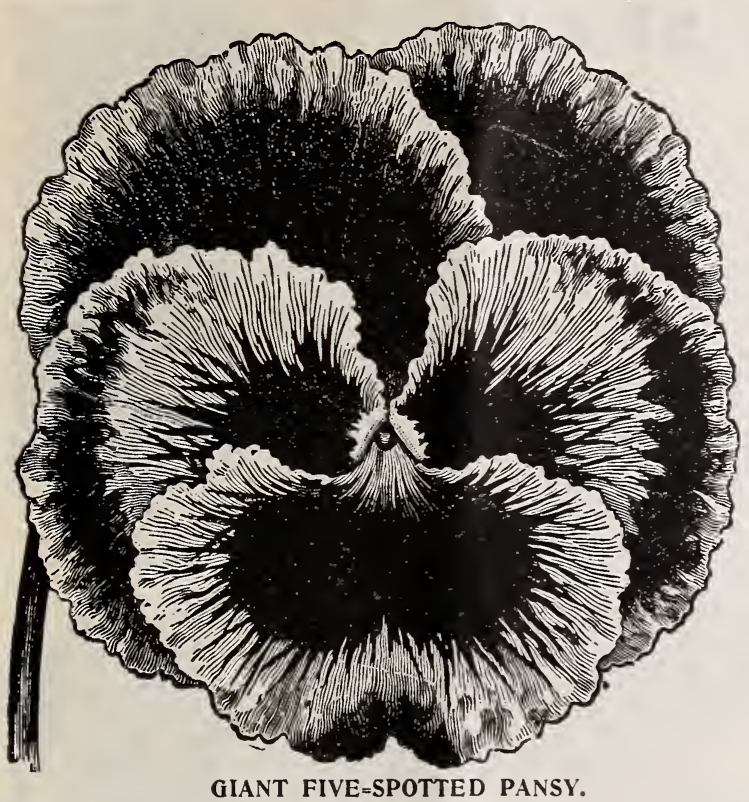

Geranium, mixed

Per Pkt.

Gypsophilia, mixed

Godichrysum largest, double, mixed

.$\$ 010$

Heliotrope, fine mixed. .

Hollyhock, double, choicest mixed

Double, pure white

Double, red. . .

Hyacinth Bean, dolichos lablab, mixed, all colors Ipomea, bona nox (Good night

Grandiflora alba, Moonflower, white seeded

Larkspur, Double Dwarf, mixed.

Linum,

Love Grove, nemophilia, mixed.

Love =in =a=Mist, nigellia damascena, mixed

Lupins, mixed, all colors.

Marigold, African, double, mixed French, double, mixed . Eldorado

Maurandia, mixed

Mignonette, Sweet, oz., $10 \mathrm{c}$ Matchet.

Golden Queen.

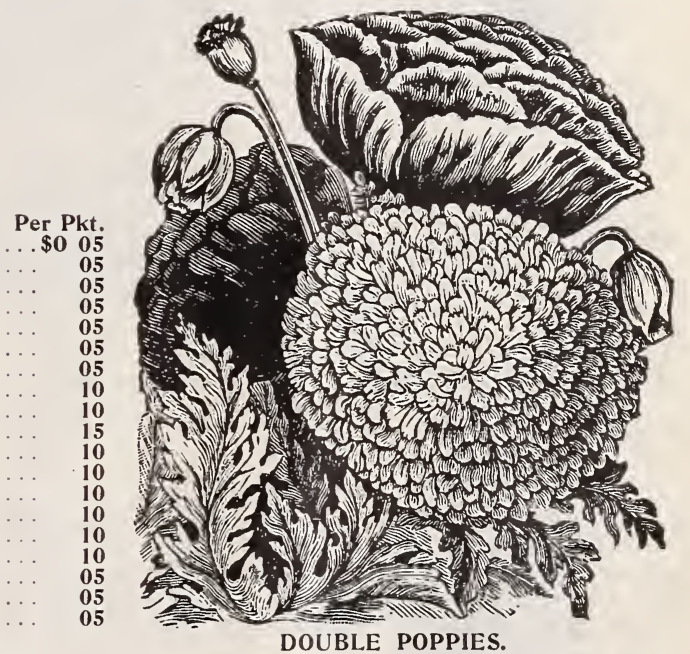

Mimulus Moschatus, Musk plant.

Morning Glory, Convolvulus Major, mixed, $\frac{1}{4} \mathrm{lb}$., i isc.; oz., 10c White.

Blue. ...

Crimson. .......................

Mourning Bride, dwarf, double, mixed, Scabiosa.

Pansy, Emperor William . .

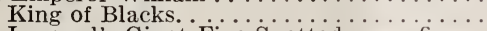

Leonard's Giant Five-Spotted, very fine. ..

Giant Striped

Odier, large stained. .

Red Flowered Victoria ..............

Peacock. . .

Large Flowered Parisian, very large stained

Trimardeau.

Extra choice, mixed...

Fine, mixed

White.....

Pansy, Yellow.............. Butterfy............. 10

Purple....

10

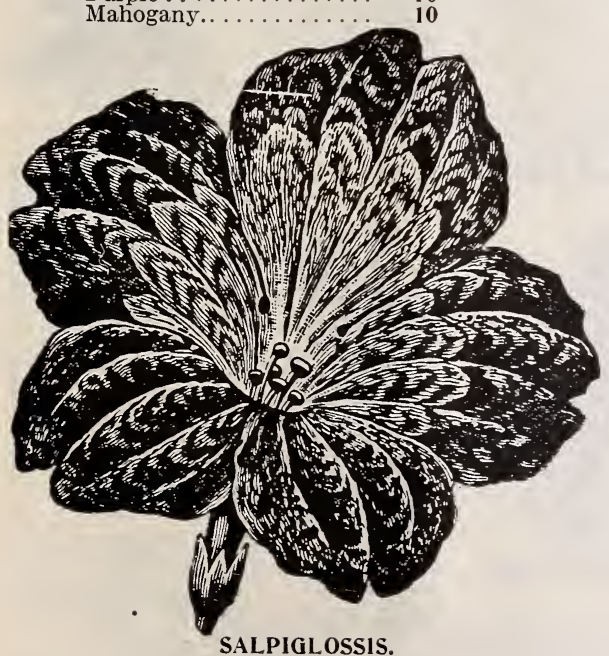

Pansy, Beaconsfield. Cardinal . .

$\$ 0 \quad 10$ Blue.

Poppy, Carnation, mixed

Snowdrift

Mikirley

Portulacca, White.

Pink.

Scarlet. . .

Crimson.

Double, mixed

Primrose, choice mixed fimbriata.

Passiflora cœrula.

Ricinus, (Castor Oil Plant), mixed, oz., 10c

Zanzibarensis, mixed, immense foliage, oz., 10c

Salpiglossis, extra fine, hybrid varieties, mixed.

Salvia Splendens.

Sensitive Plant, Mimosa pudica.

Snapdragon, Antirrhinum, finest, mixed.

Pinks, Dianthus, Chinensis, double China Pinks, mixed.

Heddewig's Double Diadem, mixed, very fine. . .

Heddewig's Finest Single, mixed.\$0 05 Crimson Belle, double, crimson.

Petuni Eastern Quee

Double, Superb, mixed

Phlox, Drummondi, Star.

Alba, pure white.

Carmine. red.

Black Warrior.

Per Pkt.

Splendid, mixed .

Stocks, double, German, ten weeks, mixed. Sunflower, Globosus fistulosus, double.

Sweet William, single, mixed, fine.

Verbena, Defiance, deep scarlet.

$$
\text { Blue. }
$$

White. .............. mixed

Mine, mixed extra choice, mixed.

Wallflower, double, mixed, extra fine

Zinnia, Pompon, finest mixed.......

Choicest mixed. . .............

$\$ 0 \quad 05$
05
05
10
10
10
10
05
10
05
05
05

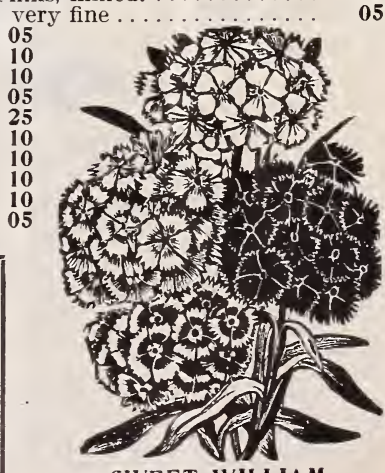

Notice our Sweet Peas and Nasturtiums, page.24,

also the Special Strains of Poular Flowers, page 25. 


\section{GRASS SEED.}

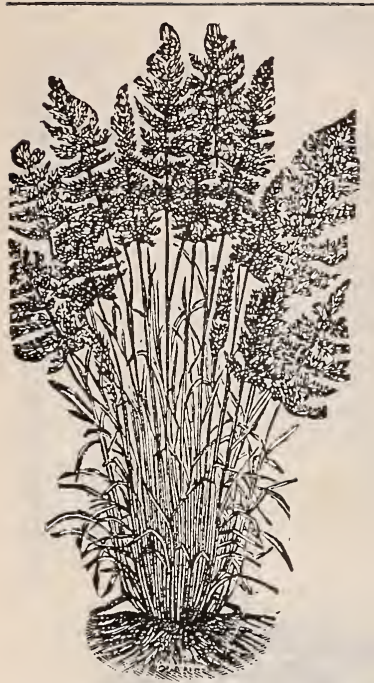

RED TOP. (Agrostis Vulgaris.) A valuable grass for moist soils and low lands. It is a good, permanent grass, standing our climate as well as any other, and consequentin well suited to our pastures close. Fourteen-pound bushel.

Solid Seed, Best Grade. Market Price.

Chaff Seed, Market Price.

TIMOTHY. (Phleum Pra= tense.) This is decidedly the best grass for hay, making a large return on strong, rich clay, of medium state

ITALIAN RYE GRASS. (Lolium Italicum.) A valuable European variety, adapted to any climate, and produces large andeen-pound bushel. Market Price.

ENGLISH RYE GRASS. (Lolium Perenne.) A very nutritious rapid growing variety, valuable for meadows and pastures. Twenty-four-pound bushel. Market Price.

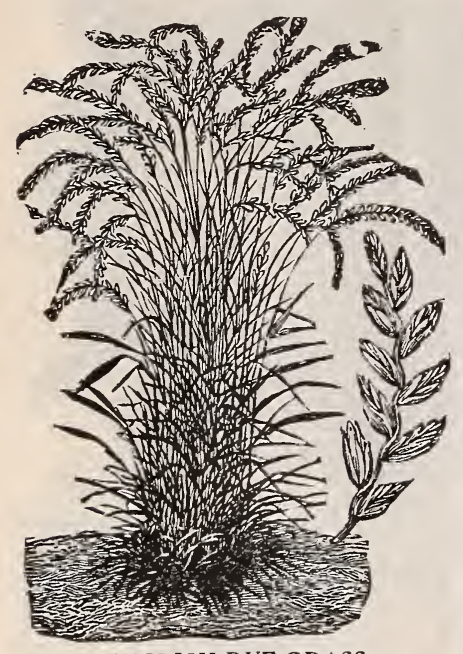

ENGLISH RYE GRASS

TALL MEADOW OAT GRASS. (Avena Elator.) This produces an abundant is valuable for pasturage on account of its early and luxuriant rowth. Market Price. GRASS (A Than thum Odoratum.) Permanent $p$ as t u res hould not be sown without a portion of this grass. Market Price. (Festuca Duriuscula.) Similar to Sheep's Fescue, but not so dense, and growing omewhat taller. This often will cover sandy oil under the shade of large trees where no other grass will grow; is a desirable grass. Sow thir t y pounds per

\section{CLOVER SEEDS.}

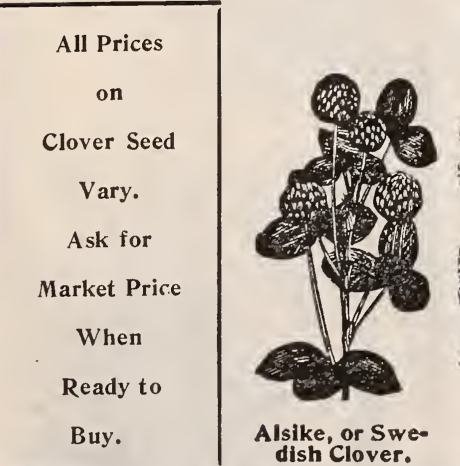
Market Price.
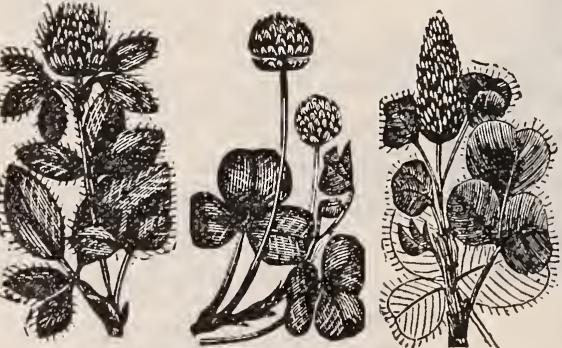

TALL FESCUE. (Festuca Elatior.) A valuable perennial grass, very productive and nutritious. It is native to moist, heavy soil, where it probably does best, but it succeeds well on any good foil, wet or dry. If used alone, sow

BLUE GRASS. (Poa Pratensis.) Commonly called Kentucky Blue Grass and known in some sections as "Green Meadow Grass" and "June Grass." It soil, succeeding finely on hill lands and producing the most nourishing food for cattle, retains its qualities to a late period in winter, and further south, affording Sowdant food throughout the winter. months of October and November Fancy clean seed. Market Price.

BLUE GRASS. Market Price. very valuable grass for pasture and lawns. For many purposes this is preferable to any of the "poa"species. Market Price. FOOTHARDGRASSOR ROUGHCOCKS (Dactylis Glomorata.) This is of the most valuable and widely known of all pasture grasses, coming in the autumn than any other. Blooms with red clover, making with it an admirable hay. It is well adapted for sowing under trees or orchards. Market Price. BLUE GRASS. (Festuca Pratensis.) perennial grass from two to four feet high, with flat, broad leaves. It needs ground, and succeeds well on pounds per acre. Market Price.

WOOD MEADOW GRASS. (Poa Ne= moralis.) Grows from one and one-half to two feet high; has a perennial creepng root, and an erect, slender, smooth stem. One of the best varieties to sow and parks, for either hay or pasturage.

CREEPING, BENT GRASS. (Agrostis Stolonifera.) Particularly valuable for awns that are to be used as croquet and tennis grounds, because it is beneted, more than hurt by tramping, and y its bright color adds to the beauty of the lawn. Market Price. (an appearance slightly resembling Timothy. aluable for permanent pastures, and does best on good moderately moist soil. If sown alone use twenty-ive pound

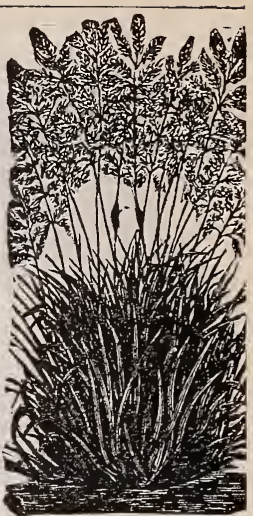

ENTUCKY BLUE

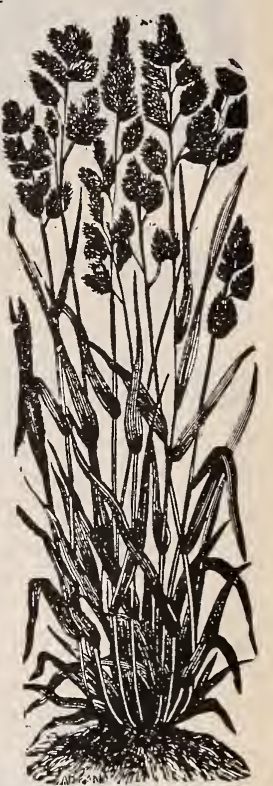

ORCHARD GRASS.

All Prices

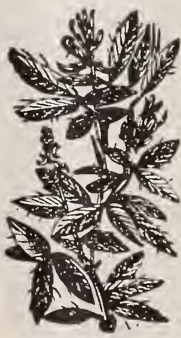

on

Grass Seed

Vary.

Ask for

Market Price

When

Ready to

Buy.

MEDIUM RED OR JUNE. (Trifolium Pratense, Thi is by far the most important of all varieties, for the practical is by far the most important of all varieties, for the practical purpose of agriculture. Sow in spring or fall,
eight or ten pounds per acre. Market Price.

MAMMOTH OR LARGE RED. (Trifolium Pratense.) It grows five or six feet high. By its judicious use lands which have been exhausted may be reclaimed. Sow at the rate of about eight pounds per acre. Sixty pounds per bushel. Market Price.

WHITE DUTCH. (Trifolium Ripens.) A small, creeping, spreading, perennial variety, valuable for pasture and lawns, spreading, peren with Blue Grass it forms the most nutritious In conjunction with Blue Grass it forms

food for sheep or cows. Market Price. valuable variety is fast gaining great popularity. It is the most hearty of all the clovers; perennial. On rich, moist soils it hite Dutch
Clover. Lucerne,
or Alfalfa. yields an enormous quantity of hay or pasture, and may be yields an enormous quantity or hay or pasture

ALFALFA OR LUCERNE. (Medicago Sativa.) One of the best varieties, succeeding in almost every situation and bearing heavy crops of forage Will bear cutting three or four times during the season. For bringing up poor land it is the best of the clovers, as it not only produces large masses of foliage, but forces its roots down fully three feet into the earth. Sow early in spring to secure a good stand before winter, if to be used for pasturage or for curing. Market Price.

CRIMSON OR SCARLET CLOVER. It can be seeded at any time from June to October, at the rate of fifteen to twenty pounds per acre, and makes the earliest possible spring pasture, blooming the latter part of April or May, and for feeding as hay should be cut just before coming into full bloom. Market Price. 


\section{Lawn Grass Mixtures.}

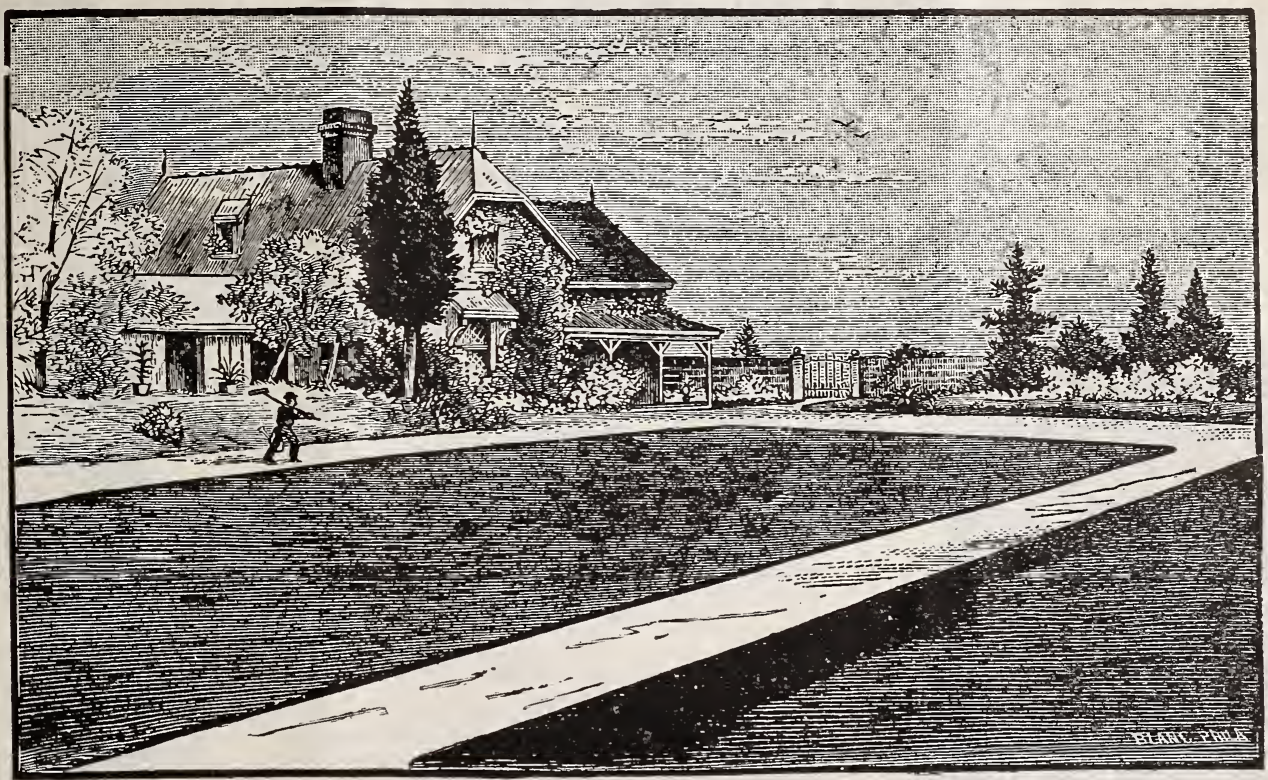

FANCY LAWN GRASS.

For quickly producing a permanent, thick and velvety sward of grass, this brand of Lawn Grass cannot be excelled. It is the best mixture of grasses we sell for lawn making, and will give satisfaction wherever sown.

\section{MIXTURE FOR SHADED SPOTS.}

Usually it is quite difficult to obtain a satisfactory growth of grass under trees and in shady places, for sowing in such places we recommend the use of this special mixture. It will quickly produce an abundant and even growth of beautiful green grass.

\section{PARK LAWN GRASS.}

This popular Mixture in all cases gives good satisfaction. A pound of seed will sow about twenty feet square.

\section{PASTURE MIXTURE.}

We mix grasses for hay or permanent pastures, suitable for any soil. The difference of location and the needs of the land to be sown make a special mixture for each individual case necessary. Name your wants as to soil and purpose and we will prepare you a mixture.

GRASS MIXTURE PRICES SUBJECT TO CHANGE, ASK FOR QUOTATIONS.

\section{Grains and Forage Plants.}

SEED WHEAT.

Saskatchewan Fife, Spring.

Scotch Fife, Spring.

Blue Stem, Spring.

Genesee Giant,Winter.

Jones Fife, Winter.

Red Wonder, Winter.

SUGAR CANE.

Early Amber.

Early Orange.

BROOM CORN.

Improved Evergreen.

Tennessee Evergreen.

Early Japanese.

SEED OATS.

Swedish Giant Flag.

American Beauty.

Giant French Hybrid.

The Lincoln.

Bonanza.

\section{COW PEAS.}

Black Eye.

Whip-Poor-Will.

Black. Seed all black. Clay Colored.

FIELD PEAS.

White Canada

Blue or Green.

Values

Change,

Ask

for

Market

Prices.

Japanese Barnyard.

Siberian.

Pearl.

Hog.

Common.

German or Golden.

Hungarian.

\section{MILLET SEED.}

\section{DWARF ESSEX RAPE.}

A forage plant of great merit, easily grown in any part of the United States, on any land that will raise turnips or corn, and will furnish abundant supplies of succulent, rich, nutritious pasture, at a season when it is most needed. It is of great value for sheep and lambs, and when turned on it, to use a common expression, "they

soon weigh like lead." It is also of value for pasturing cattle. One acre of rape is sufficient to pasture ten to fifteen lambs on for two or two and one-half months.

\section{RUSSIAN SUNFLUWER.}

This is highly prized by poultry raisers and farmers as a cheap food for fowls. It is immensely productive and can be raised cheaper than corn, as any waste piece of ground will suffice. It is the best egg producing food known.

Prices Change. Ask for Special Rates When Ready to Buy.

\section{MISCELLANEOUS.}

Spurry.

Lathyrus Sylvestris.

Barley, Commor.

Rye, Spring.

Rye, Winter.

Buckwheat, Silver Hull.

Buckwheat, Common.

Buckwheat, Japanese.

Flax Seed, for Sowing

\section{Values}

Change,

Ask for

Market

Prices. 


\section{FIELD CORN.}

\section{Prices Change. Ask for Market Price.}

EXTRA EARLY HURON DENT. After several years' trial on a large scale it is concluded that this is one of the earliest Dent corns grown. Good-size stalk and ear, small red cob, long, deep grain, very rich in oil and starch, and is the only smooth, very early Dent corn known.

PRIDE OF THE NORTH. This famous corn still retains its popularity; an exceedingly early and prolific variety, always maturing in ninety days; often shelling sixty-two pounds of grain from seventy pounds of ears. Kernels closely set, large, of deep orange color; cob very small and red; stalks about seven feet in height. This is, probably, the best Dent corn for general cultivation in the north.

NORTH STAR YELLOW DENT. One of the best early Dents. A safe variety to ripen in any locality.

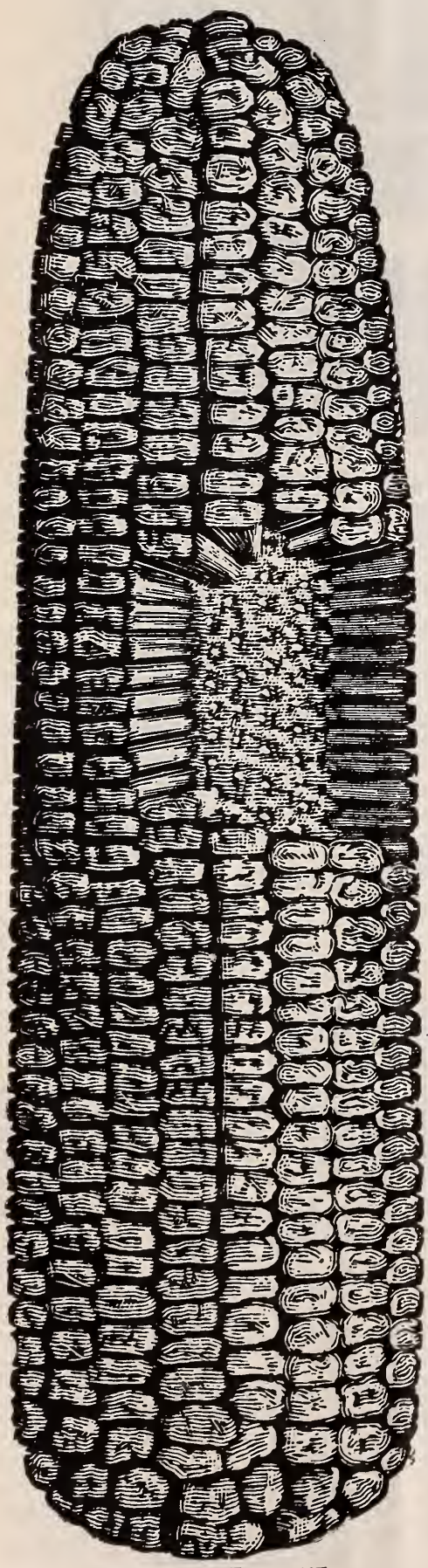

GOLDEN BEAUTY. A large, broad grained, handsome yellow corn, which is very popular in some sections of the country. Ears are of good size, color, bright golden yellow, cobs small.

MINNESOTA KING. A very early variety, in great favor with our customers in Minnesota, Wisconsin and th Dakotas, and it is considered there the most profitable and best yielding corn, no matter whether weather is favorable or not. It is a yellow half-Dent variety with broad rich golden yellow kernels.

\section{THE IMPROVED LEAMING.}

The Improved Leaming Corn is a medium early yellow variety; large, slightly tapering ears, deep grain, and medium sized red cob. In favorable years there is much uniformity of both kernels and ears. Its numerous broad leaves not only encourage a healthy development but make it a valuable variety for feeding. It has been tested from the 38 th to the $42 \mathrm{~d}$ parallels of latitude, in the past ten the 38th to the $42 \mathrm{~d}$ parallels of latitude, in the past ten range. It is one of the seven varieties recognized by the Illinois Experiment Station, where it has been first in yield more times than any other variety in "test of varieties. Numerous tests at the Experiment Station show it high in protein and oil content, making it valuable to the livestock grower and feeder.

EARLY MASTODON. A new yellow Dent, the largest and earliest in cultivation; has yielded 200 bushels to the acre.

CHAMPION WHITE PEARL. Originated in Illinois, and is enormously productive; a strong grower; mature in about 100 days. The stalk is stout and thick, with large ears set low.

IOWA GOLD MINE. A splendid new yellow corn. Everyone who has tried it is enthusiastic in the praise of this splendid new variety which was introduced in 1892 It has everywhere received the most cordial endorsement as one of the best and most profitable varieties ever grown.

IOWA SILVER MINE. The Iowa Silver Mine is a splendid new white corn. We believe that in its yield it will surpass all other varieties of any color. In 1894, the poor corn year, only three-fourths of an acre was planted, yet it yielded just seventythree bushels, or at the rate of ninety-seven and one-third bushels to the acre. It has no barren stalks. The ears are very even in size, being but little smaller at the tip than at the butt, and corn is well filled out over the tip.

LONGFELLOW FLINT. This is an eight-rowed Yellow Flint variety, the result of careful selection. The ears are from ten to fifteen inches ?ong, one and one-half to one and three-fourths inches in diameter, are well filled out to the extreme end of

CANADA EIGHT=ROWED FLINT. This standard Flint corn is the earliest of all. It is a safe corn to plant where the season is short. It will mature in eighty-five days of good corn weather.

\section{POP-CORN.}

Wisconsin Eight=Rowed, Mapledale Prolific,

White Pearl,

Queen's Golden,

White Rice.

\section{ENSILAGE AND FODDER CORN.}

If planted in drills, which should be about three and a half feet apart, twelve to ixteen quarts If sown broadcast, two to two and a half bushels are required to the acre. These prices include bags and delivery to depot. fodder.

YELLOW DENT ENSILAGE. The large growing Yellow Dent varieties make splendid fodder.

SWEET CORN FOR FODDER. There is nothing better for green feed, or for ng for winter, than sweet corn Sow in drills or broadcast.

RED COB ENSILAGE. A most desirable variety, adapted to all sections of the country.

\section{BROOM CORN.}

TENNESSEE EVERGREEN. More largely grown in the western states than any other. It ripens early and yields heavy crops.

MISSOURI EVERGREEN. Has coarser brush than the Tennessee, and is therefore desirable for making heavy brooms. 


\section{The Barker Weeder.}

It operates on the plan of a lawn mower. It is better than a hoe. It is ten times as fast. It is easy to operate. It forms a dust mulch. Buy a Barker Weeder and Mulcher and cut your garden the same as you buy a lawn mower to cut your lawn. Cut your weeds in your garden once a week. It cuts the weeds under the ground as well as the weeds out of the ground. It pulverizes the ground fine which holds the moisture to feed the plant.

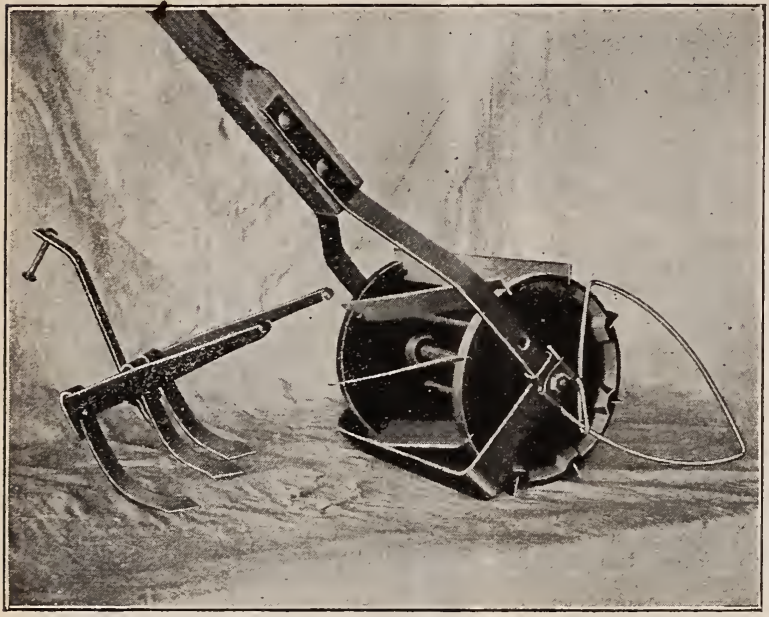

The Wire Leaf Guards Protect the Tops When the Crop is Far Advanced.

\section{IT HAS NO RIVALS.}

It is so different from all others that it is in a class by itself.

You will be interested in it as soon as you see it. When you have seen the kind of work it does you will want it.

It makes no difference how many other'hand cultivators you have or have used, you will be convinced after trying it that this one does different work from any of them and that it will pay you to have one.

To appreciate the value of this tool you must take it to the field, you cannot judge it properly by looking at it. Take it out into the patch, pick out a piece of vegetation that needs weeding. Notice the work it does. Let your man work it. If you are not satisfied with it after giving it a fair trial, you can return it. Hundreds of the best market gardeners and onion growers have taken this tool to try and have kept it and bought more. It is a money saver.

The revolving blades of the Barker do far better work than the stationary bolted knives used on other machines. With the revolving blades of the Barker the surface of the ground is chopped, the weeds are cut, separated from the soil and thereby destroyed.

The Onion Set Crop is probably the most expensive one to weed of any grown in this country. With this in mind the following from one of the largest growers of that crop speaks well for the Barker Weeder and Mulcher:

When I first saw the Barker Weeder and Mulcher I did not think it would do any better work than some others that I already had in use. I was impressed, however, by its peculiar construction and decided to give it a trial. We had thirty-five hand cultivators going on our onion set farm the day I took the Barker tool out. On my way to where the force was working I had a chance to try the tool in several different places and became satisfied that for our work it beat anything we had. In order to test it alongside of the others I called the foreman and bid him take the Barker and accompany some of his best hustlers who were working other tools. It took him a little time to get the hang of the Barker, but as soon as this was accomplished he clearly demonstrated that two rows could be done as easily with it as one could be done by any of the others. I therefore secured a quantity of the Barkers and used them in place of the others with much gain. It was well on toward the end of the weeding season when this change of tools was made and I am fully convinced, that had I secured the Barker tools at the beginning of the season, our expense for weeding would have been cut in half. My recommendation of this tool to other large growers induced them to try it and they found it as satisfactory as I did. It will do excellent work in all market garden crops.

\section{S. F. LEONARD, Chicago.}

The weeding between rows of a garden crop must be done whenever necessary right up to the time of harvest. The Barker Weeder and Mulcher is fitted with an adjustable pair of wire leaf guards which lift the tops of the vegetable out of the way of the knives and permit the machine to go in between the rows at any stage of the crops growth.

The Barker is made in 3 sizes. Viz: 6-inch cut, $8 \frac{1}{2}$-inch cut, and 11-inch cut. Each machine is fitted up with leaf guards and tooth attachment. 'The $8 \frac{1}{2}$-inch cut is the standard size for onion sets and ordinary market garden crops. The 6-inch is for lettuce and crops that are planted in close rows. The 11-inch for crops that are planted from 14 to 18 inches apart in the rows.

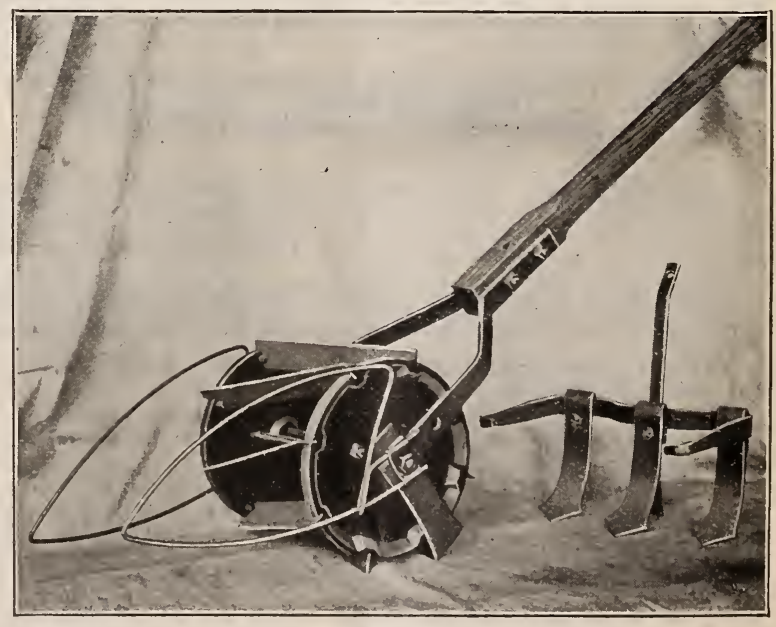

This Cut Shows the Leaf Guards on Both Sides of the Machine; Also the Tooth Attachment.

\section{Either Size Complete with all Attachments Prife $\$ 5.00$}




\section{REFERENCE TABLES.}

Quantity of Seed Requisite to Produce a Given Number of Plants and Sow an Acre.

Quantity per acre.

Artichoke, 1 oz. to 500 plants ........ 6 oz.

Asparagus, 1 oz. to 800 plants ..........

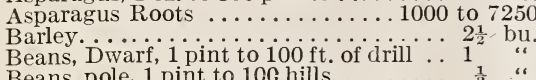

Beans, pole, 1 pint to 100 hills. . diil
Beet, garden, 1 oz. to $100 \mathrm{ft}$. of dril

Beet, mangel, $1 \mathrm{oz}$. to $100 \mathrm{ft}$. of drill

Broccoli, 1 oz. to 5,000 plants.

Brusels Sprouts, $10 z$ to 5,000 plants...2

Buckwheat

Cabbage, 1 oz to 3,000 plants

Carrot, 1 oz to 100 feet of drill

Cauliflower, 1 oz. to 3,000 plants

Celery, 1 oz. to 15,000 plants .

Chicory

Clover, Alsike and White Dutch

Lucerne ............. 15 to 25

Crimson Tiedi.......10 to 15

c. 8 to 12

Corn, rice (shelled)

Corn, sweet, $\frac{1}{4}$ pint to 100 hills............ 6

Cress, $\frac{3}{4}$ oz. to 100 feet of drill ........... 12

Cucumber, 1 oz. to 100 hills.

Egg Plant, 1 oz. to 2,000 plants
Endive, $\frac{1}{4}$ oz. to 100 feet of drill ...

Endive, $\frac{1}{4}$ oz. to 100

Flax, broadcast .......... bulbs, 1 lb. to 10 feet of dril

Gourd, 2 oz. to 100 hills

Grass, Blue, Kentucky

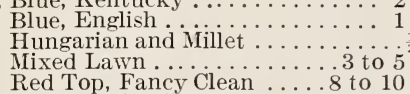

“ Red Top, Chaff Seed ....... 20 to 28

“ Timothy “..................

Hemp

Orchard, Perennial Rye, Fowl
Meadow and Wood Meadow.....

Horse Radish Roots. .

10,000 to $1^{\frac{1}{2}} 5,000$

Kale, $1 \mathrm{oz}$, to 5,000 plants

Kohl Rabi, $\frac{1}{3}$ oz. to 100 feet of drill ....

Leek, $\frac{1}{3}$ oz. to 100 feet of drill

Lettuce, $\frac{1}{4} \mathrm{oz}$. to 100 feet of drill

Martynia, $1 \mathrm{oz}$. to 100 feet of drili ......

I Ielon, Musk, 1 oz. to 100 hills. . ..... 1 to 3 Musk, 1 oz. to 100 hills. ..... 1 to 3
Water, 4 oz to 100 hills $\ldots 1 \frac{1}{2}$ to 4

Nasturtium, 2 oz. to 100 feet of drili .....15

Okra, 1 oz. to 100 feet of drill Onion Seed, $\frac{1}{3}$ oz to 100 feet of drill . 4 to 5 40 to 80

Onion Sets, 1 quart to 40 feet of drill ...

Parsnip, $\frac{1}{4} \mathrm{Oz}$. to 100 feet of drill
Parsley, $\frac{1}{1} \mathrm{Oz}$, to 100 feet of drill

Peas, garden, 1 pint to $100 \mathrm{ft}$. of drill. 1 to 3

Pepper, 1 oz. to 1,500 plants

Pumpkin, $\frac{1}{3}$ qt. to 100 hills. ............. to 4

Radish, $\frac{2}{3}$ oz. to 100 feet of drill .... 10 to 12

Rye

Salsify, $\frac{3}{4}$ oz, to 100 tzet cil drill.

Spinach, $\frac{1}{2}$ oz, to $10 \mathrm{c}$ feet of drill.

Spurry.

Summer Savc

Squash, Summer, $\mathrm{oz}$ to 100 hills Winter, $>z$ to 100 hills

Tomato, 1 oz. to 4 oc plants.

Tobacco, 1 oz. to 5000 plants........... 2

Turnip, 1 oz. to 250 feet of drill ....... i to 3

Number of Plants or Trees to the Acre at Given Distances.

Dis. apart. No. plants.

$12 \mathrm{x} 1$ in. ... . 522,720

$\begin{array}{r}12 \times 12 \\ 12 \times 12\end{array} \cdots \ldots . \quad 174,240$

$12 \times 12$ “
$16 \times 1$

$18 \mathrm{x} \quad 1$ “ $\cdots . .3348,480$

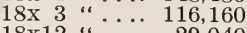

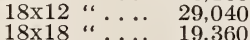

$20 \mathrm{x} 1$ “ $\cdots \cdots 313,63$

$20 \times 20$ “ $\cdots \cdots \cdot 15,681$

$24 \mathrm{x} 1$ “.... 261,360

$24 \times 18$ “....

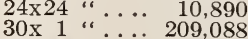

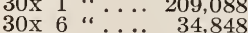

$\begin{array}{lll}30 \times 12 & \text { “ } \ldots . . & 34,848 \\ 30 \times 12 & \cdots & 17,424\end{array}$

$\begin{array}{lll}30 \times 12 & \text { “ } \ldots . . & 17,424 \\ 30 \times 16 & \ldots \ldots & 13,068\end{array}$

$30 \times 20 \quad \cdots \cdots \cdots \quad 10,454$

$30 \times 24$ “ $\cdots, \quad 8,712$

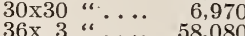

$\begin{array}{lll}36 \times 12 & \text { “ } \cdots \cdots & 58,080 \\ 36,520\end{array}$

$36 \times 18$ “.... $\quad 9,680$

Dis. apart. No. plants.

$36 \times 36$ in. ... 4,480

$42 \times 12$ “ $\cdots . .12,446$

$42 \times 24$ “ $\cdots \cdots \quad 6,223$

$42 \times 36$

$48 \times 12$

$48 \times 24$

$48 \times 30$

$48 \times 36$

$48 \times 48$

$60 \times 36$

$60 \times 48$

$8 \times 1 \mathrm{ft}$

$8 \times 3$

$8 \mathrm{x}$
$10 \mathrm{x}$
1

$10 \mathrm{x} 1$

$10 \times 10$

$12 \times 1$

$12 \times 5$

“

$16 \times 11$ “ $\cdots$

7,260

10,890

7,790

4,356

3,630 736

302
2,722
WEIGHT PER CUBIC FOOT.

Hay, well settled .... $4 \frac{1}{2}$ lbs

" shelled, “" ..45

Wheat,

Potatoes,

48
25
$35^{\frac{1}{2}}$

s. Average Time Required for

Garden Seeds to Germinate.

Bean ...

Beet..

Cabbage

Carrot.

Cauliflower.

Celery

Corn

Eucumber

Endive.

Onion.

Pnion

Parsnip

Pepper

Radish

Salsify

Tomato

Time Required for Maturity of Different Garden Crops

Reckoned from the

Day of Sowing

the Seed.

Beans, String

Beans, Shell

Beets, Turnip

Beets, Long Blood

Cabbage, Early

Cauliflower.

Corn

Eggplant.

Lettuce.

Melon, Water

Ielon, Mush

Onion

Pepper

Radish

Squash, Summer

\begin{tabular}{c|l} 
DAYs & Barley \\
5 to 10 & Beans,
\end{tabular}

7 to 10 Beans, Casto

12 to 18 Broom Corn Seed

5 to 20 Carrots

6 to 10 Coal, stone

5 to 10 Coke.

6 to 8 Corn, shelled

7 to 10 Corn ear.

6 to 10
10 to 20 Corn Meal

9 to 14 Dried Peaches

3 to 6 Flax Seed

7 to 12 Grass Seed, Blue

Hungarian

Orchard

Red Top

Timothy

German Lupin

Hemp Seed.

Hickory Nuts

Mineral Coal

Middlings, fine.

Squash, Winter

Tomato

DAYS.

45 to 65
65 to 70 Oats.

Onions

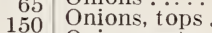

105 Onions, sets

150 Osage Orange

110 Parsnips

150 to 160 . Potatoes, Sweet

65 Peas, dried

120 to 140 Peas, in pods

120 to 140 Pup

140 to 150 Rye

30 to 45 Salt, coars

30 to 45 Salt, fine

65 Turnips, Rut'b'ga

150 Turnips, white

60 to 70 Wheat
5. to 10 Buckwheat

5 to 10 Beets.

\begin{tabular}{|c|c|c|c|c|c|c|c|}
\hline$\stackrel{\dot{\infty}}{\rightleftarrows}$ & $\overbrace{0}^{\pi}$ & $\stackrel{\dot{D}}{2}$ & $\stackrel{\frac{\varrho}{3}}{\varrho}$ & $\underset{\Xi}{\overparen{\Xi}}$ & $\stackrel{0}{ٍ}$ & $\begin{array}{l}\check{z} \\
z\end{array}$ & $\frac{0}{3}$ \\
\hline 24 & 24 & 28 & 22 & 25 & 24 & 22 & 22 \\
\hline $\begin{array}{l}50 \\
20\end{array}$ & 20 & $\begin{array}{l}57 \\
20\end{array}$ & 20 & $\cdots$ & $\dot{0}$ & & \\
\hline $\begin{array}{l}20 \\
48\end{array}$ & $\begin{array}{l}20 \\
48\end{array}$ & $\begin{array}{l}20 \\
48\end{array}$ & $\begin{array}{l}20 \\
48\end{array}$ & $\ddot{4} \dot{8}$ & $\begin{array}{l}20 \\
48\end{array}$ & $\begin{array}{l}20 \\
48\end{array}$ & $\begin{array}{l}20 \\
48\end{array}$ \\
\hline 60 & 60 & 60 & 60 & 60 & 60 & $\begin{array}{l}\text { to } \\
62\end{array}$ & $\begin{array}{l}40 \\
60\end{array}$ \\
\hline 46 & 46 & 46 & 46 & 46 & 46 & 46 & 46 \\
\hline 52 & 52 & 50 & 48 & 50 & 52 & 48 & 50 \\
\hline 46 & 46 & 46 & 46 & 46 & 46 & 46 & 30 \\
\hline 55 & $\cdots$ & $\begin{array}{l}50 \\
50\end{array}$ & . & $\cdots$ & 50 & . & $\begin{array}{l}50 \\
50\end{array}$ \\
\hline 22 & 22 & 22 & 22 & 22 & 22 & 22 & \\
\hline 80 & 80 & $\cdots$ & $\ldots$ & $\ldots$ & 80 & $\cdots$ & 80 \\
\hline 40 & 38 & & & & & & 40 \\
\hline 56 & 56 & 56 & 56 & 56 & 56 & 56 & 56 \\
\hline 48 & 48 & 48 & 50 & $\begin{array}{l}68 \\
50\end{array}$ & 50 & 50 & 68 \\
\hline 33 & & & 40 & $\begin{array}{l}30 \\
33\end{array}$ & & & \\
\hline 23 & 23 & 28 & 28 & 33 & 33 & 32 & 33 \\
\hline 56 & 56 & 56 & 56 & 56 & 56 & 55 & 56 \\
\hline 14 & 14 & 14 & 14 & 14 & 14 & 15 & 10 \\
\hline 60 & 60 & 60 & 60 & 60 & 60 & 60 & 60 \\
\hline 48 & 48 & 48 & 50 & 50 & 48 & 48 & 50 \\
\hline $\begin{array}{l}0 \\
14\end{array}$ & $\begin{array}{l}48 \\
14\end{array}$ & 50 & $\begin{array}{l}50 \\
14\end{array}$ & $\begin{array}{l}50 \\
14\end{array}$ & $\begin{array}{l}50 \\
14\end{array}$ & $1 \dot{4}$ & $\begin{array}{l}50 \\
14\end{array}$ \\
\hline 14 & 14 & 14 & 14 & 14 & 14 & 14 & 14 \\
\hline 45 & 45 & 45 & 45 & 45 & 45 & 44 & 45 \\
\hline $\begin{array}{l}00 \\
44\end{array}$ & 44 & 44 & 44 & 44 & 44 & 44 & \\
\hline 50 & & & & & & & \\
\hline 38 & 36 & 34 & 38 & 38 & 38 & 34 & 34 \\
\hline 40 & $\cdots$ & $\cdots$ & . & 70 & $\ldots$ & . & $\Rightarrow$ \\
\hline $\begin{array}{l}40 \\
30\end{array}$ & $\cdots$ & . & . & $\begin{array}{l}40 \\
30\end{array}$ & . & . & \\
\hline 32 & 32 & 32 & 32 & 32 & 32 & 32 & 32 \\
\hline 57 & 57 & 57 & 54 & 48 & 57 & 57 & 50 \\
\hline 28 & 28 & 28 & 28 & 28 & 28 & 28 & 25 \\
\hline $\begin{array}{l}52 \\
33\end{array}$ & $\cdots$ & . & . & $\cdots$ & $\cdots$ & . & \\
\hline 55 & & & & 55 & $\dot{4} \dot{4}$ & $\cdots$ & \\
\hline 60 & 60 & 60 & 60 & 60 & 60 & 60 & 60 \\
\hline 50 & 46 & 55 & 56 & 55 & 56 & 55 & 50 \\
\hline 60 & 60 & 60 & 60 & 60 & 60 & 60 & 60 \\
\hline 70 & $\cdots$ & t & 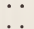 & $\dot{7} \dot{0}$ & & $\cdots$ & \\
\hline 80 & 80 & 80 & 80 & 80 & 80 & 80 & \\
\hline 56 & 56 & 56 & 56 & 56 & 56 & 56 & 56 \\
\hline 50 & 50 & 50 & 50 & 50 & 50 & 50 & 50 \\
\hline $\begin{array}{l}50 \\
55\end{array}$ & $\begin{array}{l}50 \\
55\end{array}$ & $\begin{array}{l}56 \\
56\end{array}$ & $\begin{array}{l}56 \\
58\end{array}$ & $\begin{array}{l}50 \\
55\end{array}$ & $\begin{array}{l}50 \\
50\end{array}$ & $\begin{array}{l}56 \\
55\end{array}$ & 60 \\
\hline 60 & & 42 & & & 42 & & \\
\hline 60 & 60 & & 60 & 60 & 60 & 60 & \\
\hline
\end{tabular}

6 to 12 “ Clover

egal Weights and Measures

POUNDS PER BUSHEL.

\section{Valuable Horticultural Books.}

\section{Sent Postpaid on Receipt of Price.}

Asparagus Culture, Flex. cloth ... $\$ 0.50$ Gregory on Cabbage ........... $\$ 0.30$

Barry's Fruit Garden, New and Re- 1.50 Gregory on Carrots and Mangels .. $\quad .30$

Bee Culture, A B C of, Root, A. L. . 1.25 Henderson's Gardening for Profit . 1.50

Bommer's Method of II a ki ng 25 Henderson's Gardening for Pleasure 1.50

Brill's Cauliflower

Brill's Cauliflower $\ldots \ldots \ldots \ldots$. $\ldots \ldots$.
Brill's Farm Gardening and

Broom Corn and Brooms

Breck's New Book of Flowers

Burr's Vegetables of America

C. L. Allen.

Dahlia, the Peacock, L K

Downing's Fruits and Fruit Trees

of America, New Edition ......

.25 Henderson's Practical Floriculture 1.50

Henderson's Hand-Book of Plants 3.00
Home Floriculture, by Eben R.

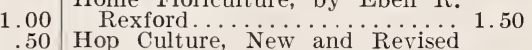

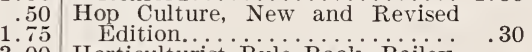

3.00 Horticulturist Rule Book, Bailey,

1.50 House Plants-How to Succeed, L.

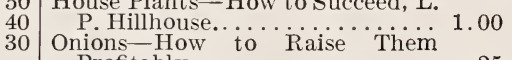

5.00 Plums and Pium Culture, Waugh,

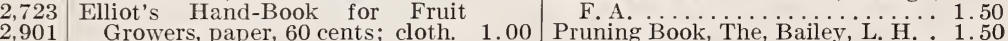

2,178 Erowers, paper, 60 cents; cloth.

1,743 Feathered Pets, on the Care of

5,445
1,815 Flower Garden, Beautiful, Mathew.

.50 Rose, The, Its Cultivation, Ell-

25 Small Fruit Culturist. Fuller, A. S. 1.00

40 Strawberry Culturist. Fuller, A. S.
60 Thomas' American Fruit Culturist 2.00 Tobacco Culture, by fourteen experienced cultivators. ........... . 25

4,356 Fruit Growing, Amateur, by $\mathrm{S}$. B.

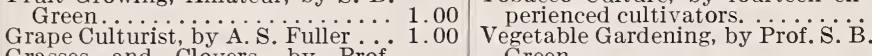

.25

3,630 Grasses and Clovers, by Prof.

50 Window Flower Garden, Henrich's $\begin{array}{r}1.25 \\ .50\end{array}$

At the-prices above named the books will be mailed, postage paid, on receipt of

the money. 


\section{Harvey Seed Co.}

All Kinds of High Grade

Garden, Field and Flower

Seeds, Onion Sets

Incubators and Poultry Supplies WHOLESALE and RETAIL

Special quantity prices made to

Market Gardeners.

Mail orders solicited.

MONTGOMERY, ALA.
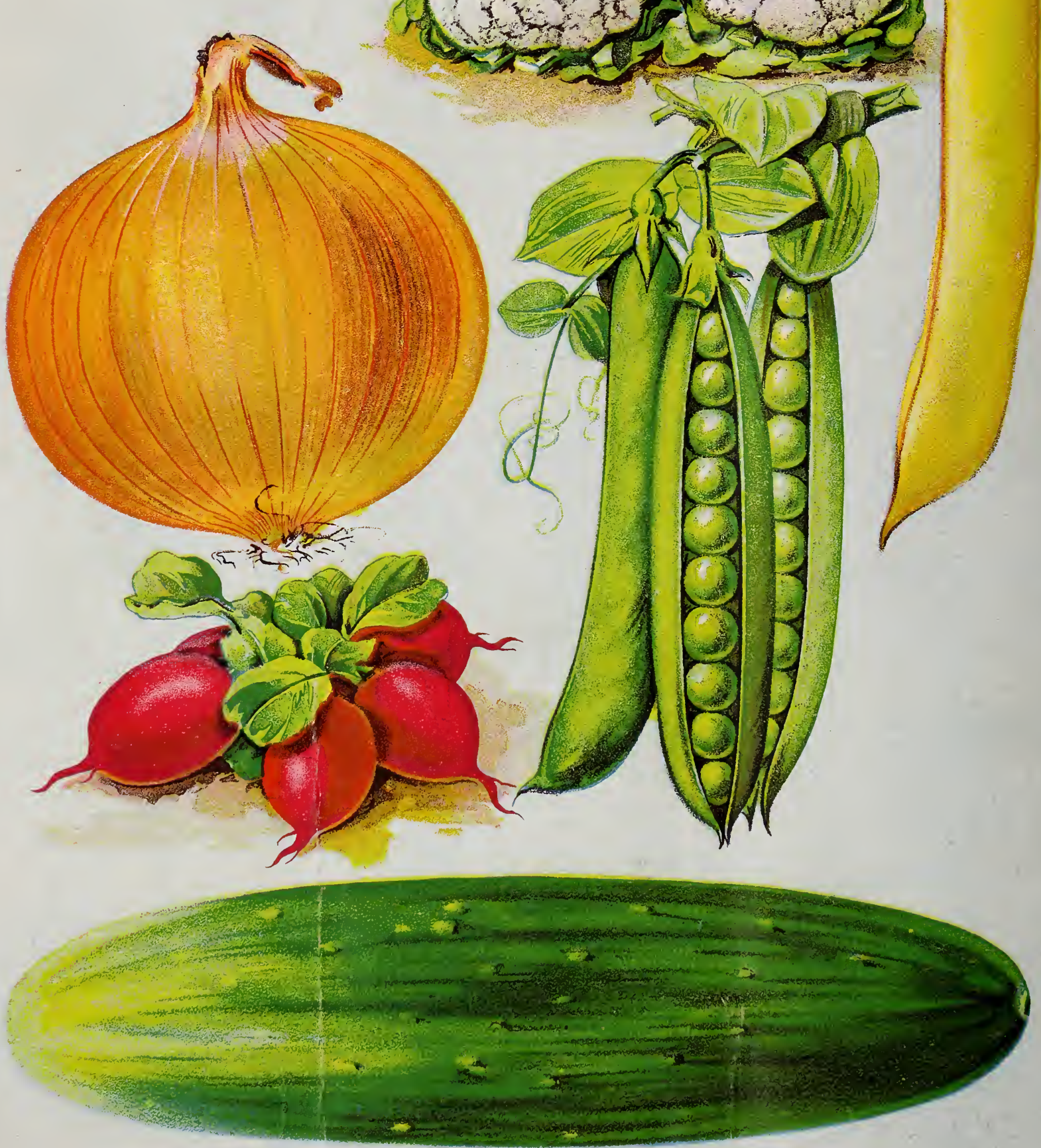